\title{
DA USUCAPIO: A QUESTÃO DO TÍTULO PUTATIVO NO DIREITO ROMANO
}

\begin{abstract}
Dissertação apresentada à Banca Examinadora do Programa de Pós-Graduação em Direito da Faculdade de Direito da Universidade de São Paulo como exigência parcial para obtenção do título de Mestre em Direito, na área de concentração 2141 Direito Romano e Sistemas Jurídicos Contemporâneos, sob a orientação do Prof. Titular Dr. Eduardo César Silveira Vita Marchi.
\end{abstract}

UNIVERSIDADE DE SÃO PAULO

FACULDADE DE DIREITO

SÃO PAULO - SP 
À minha esposa Yasmin. 


\begin{abstract}
Agradeço
Aos professores da área de Direito Romano e Sistemas Jurídicos Contemporâneos da Faculdade de Direito da USP, Prof. Dr. Hélcio Maciel França Madeira, Prof. Dr. Bernardo Bissoto Queiroz de Moraes e Prof. Dr. Dárcio Roberto Martins Rodrigues e, especialmente, ao meu orientador, Prof. Titular Dr. Eduardo César Silveira Vita Marchi, a quem dedico admiração, amizade, respeito e gratidão.

Aos amigos pesquisadores, Samanta Takashi, Helmut Steinwascher, Ricardo Savignani Alvares Leite, Tomás Olcese, João Costa Neto, Gustavo Lima Martins e Fabiana Barros de Martin, indispensáveis nessa jornada.
\end{abstract}




\section{ÍNDICE}

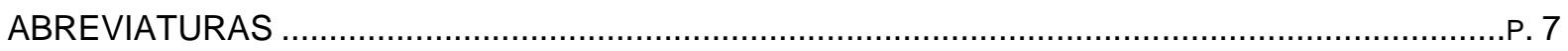

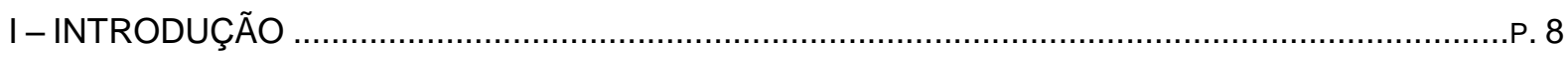

II - AS MODALIDADES DE IUSTAE CAUSAE USUCAPIONIS E O TÍTULO PUTATIVO ................. P.13

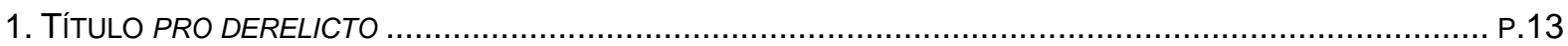

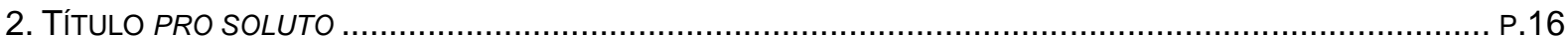

2.1. O TÍTULO PRO SOLUTO E SUA CORRELAÇÃO COM O TÍTULO PRO SUO ................................ P.21

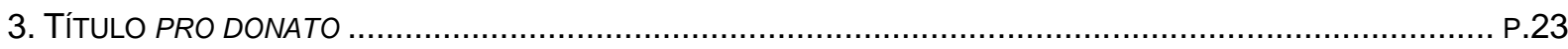

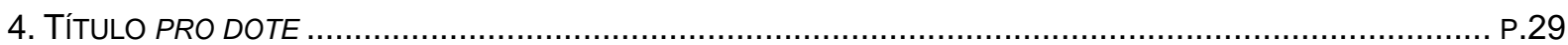

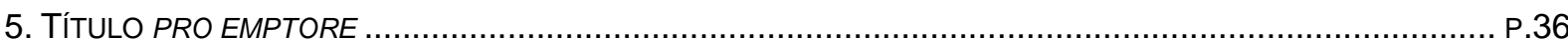

5.1.O TÍTULO PRO EMPTORE E A EMPTIO-VENDITIO ……................................................ P.38

5.2 . O MOMENTO DA BOA-FÉ NO TÍTULO PRO EMPTORE .................................................. P.41

5.3. O PAGAMENTO DO PREÇO COMO CONDIÇÃO ESSENCIAL PARA O USUCAPIÃO ......................... P.53

5.4. Considerações ACERCA do debATE ENTRE PROCULEIANOS E SABINIANOS SOBRE O MOMENTO

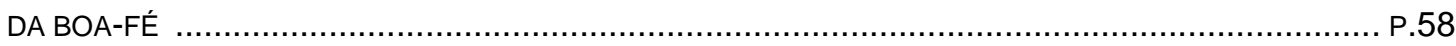

5.5. CONSIDERAÇÃO SOBRE O PAGAMENTO DO PREÇO NA USUCAPIO PRO EMPTORE ................... P.60

5.6. O TÍTULO PRO EMPTORE EM RELAÇÃO AO TÍTULO PUTATIVO ............................................. P.61

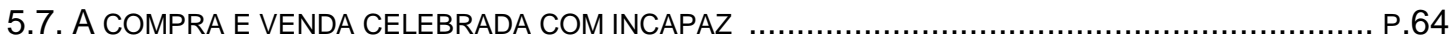

5.8. A DIVERGÊNCIA EM RELAÇÃO À PUBLICIANA ............................................................... P.72

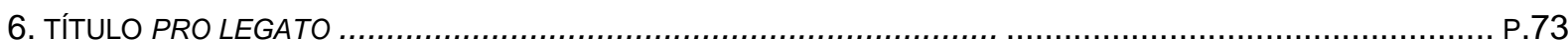

6.1. A ADMISSÃO DO USUCAPIÃO COM BASE EM UM LEGADO NULO ......................................... P.78

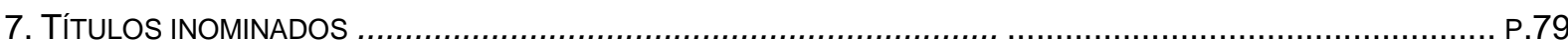


7.1. O JURAMENTO E A SENTENÇA

7.2. A ACTIO UTILIS E A LONGI TEMPORIS PRAESCRIPTIO

7.3. A EFICÁCIA DA COISA JULGADA

8. TÍTULO PRO SUO P.90

9. O ALEGADO USUCAPIÃO PRO HEREDE DO HERDEIRO VERDADEIRO P.102

9.1. ORIGEM E CARACTERÍSTICAS ESPECIAIS DO USUCAPIÃO PRO HEREDE DO HERDEIRO APARENTE NO DIREITO JUSTINIANEU. P.106 P.108

III. CONCLUSÃO

RESUMO .P. 140

ABSTRACT P. 141

BIBLIOGRAFIA P. 142 INDICE DAS FONTES P. 144 


\title{
Principais Abreviaturas
}

\author{
C. \\ $=$ Codex Iustinianus \\ D. \\ = Digesta \\ ED \\ = Enciclopedia Del Diritto (Milano) \\ Frag. Vat. \\ = Fragmenta Vaticana \\ Inst. \\ = Institutiones Iustiniani \\ IURA \\ = Rivista Internazionale di Diritto Romano e Antico (Napoli) \\ Labeo \\ = Rassegna di Diritto Romano (Napoli) \\ NDI \\ = Nuovo Digesto Italiano \\ NNDI \\ = Novissimo Digesto Italiano (Torino) \\ RIDA \\ = Revue Internationale des Droits de l'Antiquité (Bruxelas)
}

\footnotetext{
* Nas notas de rodapé, como regra, se fará menção somente à primeira nota onde todos os dados bibliográficos de uma determinada obra foram citados pela primeira vez, não se repetindo a mesma informação nas notas subsequentes. Por exemplo: P. BonfanTE, Le singole cit. (nota 10 supra), p. 553. De acordo com o exemplo, os dados completos do livro serão encontrados na nota 9 do trabalho e as informações citadas serão encontradas na página 553 da obra. A referência aos autores, no corpo do texto e nas notas, será feita com a abreviação dos prenomes e a menção do sobrenome por extenso e em caixa alta (v.g., P. BONFANTE). Excepcionalmente, os nomes dos autores luso-brasileiros serão mencionados como conhecidos na comunidade acadêmica nacional. Com relação aos jurisconsultos romanos e aos autores medievais, os seus nomes sempre serão mencionados em minúscula (v.g, Nerácio, Paulo, Próculo, Papiniano, Ulpiano, etc). As traduções dos fragmentos citados no trabalho foram feitas pelo próprio autor, com base nas seguintes traduções em espanhol: em relação aos fragmentos do Digesto: D'Ors, Álvaro, Hernandes, Francisco, FuentesecA, Pablo, Garcia-Garrido, Manuel e BuRILlo, Jesus, El Digesto de Justiniano, Tomos I, II e III, Pamplona, Aranzadi, 1975 e em relação ao Codex: Garcia Del Corral, Ildefonso, Cuerpo de Derecho Civil Romano, Tomos IV e V, Barcelona, Lex Nova, 1892.
} 


\section{INTRODUÇÃO}

A usucapio romana, desde sua origem nas XII Tábuas, onde se previa sua fórmula inicial "usus auctoritas fundi biennium, ceterarum rerum annuus est usus ${ }^{2}$ " passou por divesas transformações, as quais acarretararam agitados debates pela jurisprudência em relação aos seus requisitos, até a definitiva configuração determinada por Justiniano.

Uma das principais controvérsias, segundo J.C MOREIRA ALVES ${ }^{3}$, refere-se à exigibilidade do título, especialmente se este, enquanto requisito da usucapio, deveria ter existência real e objetiva ou se apenas bastava a crença da sua existência por parte do possuidor (título putativo).

No que se refere à discussão entre os jurisconsultos sobre a efetiva existência do título, A. CORREIA - G. SCIASCIA ${ }^{4}$ afirmam que os juristas clássicos julgaram não ser suficiente o título putativo, embora este tenha sido admitido por Justiniano.

Para M. TALAMANCA ${ }^{5}$ as principais evoluções nas relações entre a iusta causa, a bona fides e o título putativo ocorreram entre os séculos I e II.

Em princípio, a iusta causa, salienta o autor, deveria ter existência objetiva, no entanto, entre o final do século I e a metade do século II alguns juristas, a exemplo de Próculo, Nerácio, Africano e Pompônio, passaram a considerar que, em alguns casos específicos, a mera convicção do possuidor acerca da subsistência da causa usucapionis seria suficiente para que se procedesse a usucapio.

Entretanto, a identificação acerca da natureza putativa de um determinado título do usucapião $^{6}$ não é tarefa das mais fáceis.

A doutrina romanística traz algumas informações que, de início, colaboram com a identificação dos principais textos acerca da cogitada admissão ou mesmo da flagrante rejeição do título putativo pelos jurisconsultos.

\footnotetext{
${ }^{2}$ S. RicCOBONO, FIRA, I, Firenze, 1941, p. 44.

${ }^{3}$ Direito Romano, 15 a ed., Rio de Janeiro, Forense, 2012, p. 325/326.

${ }^{4}$ Manual de Direito Romano, Rio de Janeiro, SEDEGRA, 1968, p. 136.

${ }^{5}$ Istituzioni di Diritto Romano, Milano, Giuffrè, 1990, p. 426.

${ }^{6}$ Quanto ao gênero gramatical, trata-se de um substantivo de dois gêneros, consoante dicionário Lexicon Aulete. Neste trabalho optou-se pelo gênero masculino.
} 
Todavia, o primeiro vestígio que se verifica é que, não obstante o título represente um requisito essencial da usucapio, quando diz respeito ao título putativo a sua análise deve ser realizada em consonância com outro requisito fundamental, a boa-fé.

Segundo M. TALAMANCA ${ }^{7}$, os juristas romanos procediam de vez em quando a uma avaliação da circunstância concreta que ensejaria a justificação do erro, portanto, seria realmente difícil identificar em quais situações o título putativo teria sido realmente admitido.

Assevera G. MAY $^{8}$ que o pensamento que teria prevalecido na última era do direito - e que teria sido consagrado por Justiniano -, seria de que a crença na existência de uma justa causa não poderia tomar o lugar dela.

Logo, a justa causa seria um fato jurídico independente dessa crença e muitas vezes suscetível a dar origem à propriedade ou a confirmá-la, razão pela qual, tem natureza absolutamente objetiva.

Esse afastamento da boa-fé e do título é também defendido por V. SCIALOJA 9 .

O estudioso salienta que o título é um elemento de índole jurídica, enquanto a boa-fé é um elemento de índole moral, por isso, um e outro devem ser considerados nitidamente separados e não em função complementadora.

A assertiva parece correta, todavia, para a compreensão do título putativo ela não parece suficiente.

Para o romanista italiano P. BonfANTE ${ }^{10}$, autor que se dedicou com afinco ao estudo das iustae causae usucapionis e do título putativo, a iusta causa exerce função limitativa em relação à usucapio, pois busca harmonizar este instituto com um princípio mais geral do direito.

A iusta causa deve sempre representar uma relação com o antigo possuidor, para que da análise do momento da tomada da posse, seja identificado se esta ocorreu sem lesão à outra parte ou a terceiros.

A boa-fé, segundo o mesmo autor, não teria função diversa. Ela deve somente expressar, de modo mais completo, a ausência intrínseca da intenção direta de lesar a outra

\footnotetext{
${ }^{7}$ Istituzioni cit (nt. 4 supra) p. 426.

${ }^{8}$ Éléments de Droit Romain, $18^{\mathrm{a}}$ ed., Paris, Recueil Sirey, 1932, p. 219.

9 Teoria della proprietà nel diritto romano, lezioni ordinate curate edite da Pietro Bonfante, 2, Spoleto, Anonima Romana, 1933, p. 129.

10 Le singole "iustae causae usucapionis" e il titolo putativo in Scritti Giuridici Varii II - Proprietà e Servitù, Milano, UTET, 1918, p. 525.
} 
parte, deduzindo o estado de ânimo do possuidor de todo o seu comportamento.

Essa nova forma de interpretar um mesmo conceito, aplicada exclusivamente para integrar a iusta causa em relação ao direito do agente, tende aos poucos a exauri-la e, em outros momentos, a superá-la.

Assim, esta integração entre a iusta causa e a bona fides, com a evolução do direito, a iusta causa usucapionis desaparece e acaba cedendo lugar para a iusta causa erroris, a qual, conforme explica o citado autor, é a base e argumento da boa-fé ${ }^{11}$.

Em estudo sobre a iusta causa e a actio Publiciana, ao dissertar sobre a relação entre a iusta causa e a bona fides, a romanista L. VACCA ${ }^{12}$ demonstrou preocupação com a ideia respaldada em grande parte da doutrina de que todas as hipóteses de usucapião poderiam se enquadrar na tutela da Publiciana.

A crítica que faz a autora é que a doutrina deixou de considerar que, em alguns casos, a usucapio poderia se proceder unicamente com base nos pressupostos originários possessio, tempus, res habilis, independentemente da iusta causa, pois a posse teria se fundado tão somente no senso de convicção de não lesar outrem.

Essa ausência de lesão fornece uma pista fundamental para a compreensão da ideia do título putativo, pois, conforme se verá nas fontes, esse atributo aliado à boa-fé do possuidor é que justificará o usucapião em determinadas situações, mesmo diante da aparente ausência do título.

A esta conclusão chegou uma parte dos jurisconsultos romanos, mas o último período da história do direito romano apresenta uma singela reação a este entendimento, a qual foi determinada por razões diversas.

Conforme T. MAYER-MALY ${ }^{13}$, as fontes relacionadas ao período pós-clássico sugerem uma rejeição retilínea e geral de todos os títulos putativos.

Para o autor, os imperadores Diocleciano e Justiniano não pretendiam permitir nenhum título putativo, do mesmo modo que seria inadequado dizer que ele rejeitaram todos esses títulos.

Aduz, ainda, que enquanto a balança pesou para a aceitação de muitos títulos putativos

\footnotetext{
${ }^{11}$ P. BONFANTE, Le singole cit. (nota 10 supra), p. 553.

12 "Iusta causa" e "bona fides" nell"' usucapio romana" a proposito del titolo "pro suo", in Sodalitas, Scritti in onore di A.Guarino, 4, Napoli, Jovene, 1984, p. 1.956.

${ }^{13}$ Das Putativtitelproblem bei der Usucapio, Graz-Colônia, Herman Böhlaus, 1962, p. 139.
} 
no período clássico, no pós-clássico essa tendência se inverteu ${ }^{14}$.

Nesse passo, assevera o citado romanista, os juristas clássicos, período em que predominou o debate acerca da admissão desses títulos, não enxergavam problemas unicamente em relação ao título putativo.

Discutiam-se, na verdade, diversas e complexas situações, portanto, não parece adequado que a doutrina simplesmente se refira ao assunto delimitando quem são seguidores e os oponentes do título putativo.

Destarte, o que se pretende no presente trabalho é analisar, especialmente com base no estudo de P. BONFANTE ${ }^{15}$, todas as modalidades da usucapio, conforme organizadas pelos compiladores justinianeus no livro 41 do Digesto, além de outros textos dos quais o citado autor considerou relevantes para a resolução da questão.

O critério a ser utilizado será o mesmo do qual se valeu o mencionado jurista italiano em seu estudo, i.e, iniciar-se-á pelas causas da qual o autor considerou as mais simples, até aquelas que, gradualmente, apresentam as maiores singularidades.

Observar-se-á primeiramente, conforme este critério, o título pro derelicto, cuja maior peculiaridade reside na questão da ocupação de coisa abandonada, quando esta se refere a uma res aliena.

Por conseguinte, será analisada a eventual existência do título putativo em relação à modalidade que foi a última a conquistar sua autonomia nos textos romanos, o título pro soluto.

Seguirá o estudo com a análise dos títulos pro donato, pro dote, pro emptore, pro legato, até que seja analisado aquele que é, talvez, o ponto mais relevante da discussão em relação ao título putativo, o título pro suo.

Em síntetese, pro suo possidere, define P. BONFANTE ${ }^{16}$, significa que alguém possuiu alguma coisa com base em uma iusta causa e se pode, portanto, usucapir, se já não se é proprietário.

Este conceito parece não ser compartilhado por L. VACCA ${ }^{17}$.

A autora critica de modo veemente os autores que procuram construir uma definição

\footnotetext{
${ }^{14}$ Das Putativtitelproblem cit. (nota 13 supra), p. 145.

${ }^{15}$ Le singole cit. (nota 10 supra).

${ }^{16}$ Le singole cit. (nota 10 supra), p. 631.

17 "Iusta causa" e "bona fides" cit. (nt. 12 supra), p. 1.959.
} 
de possessio pro suo tentando ajustá-la à possessio ad usucapionem ex iusta causa.

Segundo a autora, os textos costumam admitir que possidere pro suo significa, genericamente, possuir com a crença de ser dono e pode assumir tanto o significado de possessio de boa-fé como de possessio ad usucapionem.

Outra assertiva proliferada na doutrina romanística é a de que o título pro suo, como regra geral, se apresentava como suficiente para indicar uma iusta causa usucapionis nas situações em que os jurisconsultos se encontravam diante de uma série de justas causas, as quais não podiam ser enquadradas nas demais modalidades da usucapio.

Para $\mathrm{P}$. VoCI ${ }^{18}$ a possessio pro suo tem um duplo significado, primeiramente, é posse de boa-fé, pura e simplesmente, e em segundo lugar, pode também denotar várias hipóteses de bonae fidei e iustae causae.

Tais constatações levam à impressão, segundo L. VACCA, de que em alguns textos da possessio pro suo o título putativo poderia ser admitido, mas essa afirmação seria mal conciliada com a rigidez da possessio ad usucapionem ${ }^{19}$.

Entretanto, o problema da admissão do título putativo não se esgota apenas em relação ao título pro suo, pois os compiladores justinianeus, algumas vezes, trataram das hipóteses relacionadas a este título em textos inseridos em outros títulos pelos compiladores justinianeus, por exemplo, o dote e a justa causa.

$\mathrm{O}$ estudo de P. BONFANTE ${ }^{20}$ certamente contribuiu significativamente para a essa compreensão, o autor procurou definir a natureza específica de cada uma das iustae causae, buscando, através delas, uma comprovação sustentável do seu conceito geral.

Procurou, ainda, compreender o papel que representou o chamado título putativo no novo direito e, a partir disso, identificar as alterações que ele produziu ao conceito genuíno da iusta causa na sua relação com a boa-fé.

Propõe o presente trabalho, a partir da análise citado estudo, analisar estas iustae causae e a eventual admissibilidade do título putativo a partir dos textos romanos.

\footnotetext{
${ }^{18}$ Modo di acquisto della proprietà in Corso di diritto Romano, Milano, Giuffrè, 1952, p. 193.

19 "Iusta causa" e "bona fides" cit. (nt. 12 supra), p. 1.959.

${ }^{20}$ Le singole cit. (nota 10 supra), p. 552-682.
} 


\section{As modalidades de iustae causae usucapionis e o título putativo}

\section{Título pro derelicto}

Esta é, para P. BONFANTE, a mais simples iusta causa do usucapião.

A derrelição é uma clara figura da iusta causa, a qual se destina tanto à aquisição imediata do domínio, quanto ao usucapião.

O abandono da coisa, explica o autor ${ }^{21}$, é o momento em que se exclui toda e qualquer possibilidade de lesão ao antigo possuidor, todavia, nem por isso ele assume o caráter de um negócio obrigatório, pois em relação à aquisição real poderia, no máximo, constituir uma causa remota.

A coisa abandonada pode ser considerada como uma coisa vácua, i.e, carente de domínio alheio de modo absoluto (erga omnes), desse modo, qualquer pessoa pode afirmar sobre esta o próprio direito, sem com isso cause lesão a alguém.

Eis como tem atuação o título pro derelicto em tema de usucapião:

A ocupação de uma res derelicta assegura ao adquirente o domínio sobre a coisa, quando aquele que a abandonou era o seu proprietário.

Se, todavia, quem a abandonou - ou seja, o derrelinquente - é um non dominus, a res derelicta é uma res aliena.

É nesse ponto, portanto, que se apresenta o abandono (ou derrelição) como justa causa para fins de usucapião.

Para P. BONFANTE ${ }^{22}$ este título causa um grande embaraço na teoria dominante, pois deveria se chamar pro occupato, logo, se os romanos decidiram por não chamá-lo assim, certamente foi para manter a diferenciação do título da usucapio com o da ocupação de res nullius.

O autor afirma não compreender como poderia surgir uma confusão como essa na doutrina, especialmente, por que essa a polêmica recairia tão somente em relação ao título pro derelicto.

\footnotetext{
${ }^{21}$ P. BonfANTE, Le singole cit. (nota 10 supra), p. 553.

${ }^{22}$ Le singole cit. (nota 10 supra), p. 554.
} 
Semelhantemente, poderiam ser citados os demais títulos, a exemplo do título pro dote e pro donato.

Isso porque, com base no mesmo raciocínio, chegaria-se à mesma conclusão em relação a eles.

Logo, o primeiro indício constatado pelo autor seria o fato da doutrina não ter compreendido adequadamente o que é a iusta causa de usucapião.

Acrescenta P. BONFANTE ${ }^{23}$ que de uma confusão análoga nasceu a ideia de que o título pro derelicto seja um título putativo, porque só o verdadeiro proprietário pode abandonar a coisa.

Se essa premissa fosse válida, diz o autor, não existiria outra coisa na usucapio, senão os títulos putativos.

Os textos relativos à usucapio pro derelicto nas fontes romanas exigem a efetiva derelictio.

Isso pode ser observado em Paulo, D. 41, 7, 4, onde enuncia nitidamente o princípio que autoriza o usucapião:

$\begin{array}{lll}\text { "Id, quod pro derelicto habitum est et haberi } & \text { Podemos usucapir o que acreditamos que } \\ \text { putamus, usucapere possumus, etiam si } & \text { tenha sido e permanecido abandonado, } \\ \text { ignoramus, a quo derelictum sit". } & & \text { embora não saibamos quem o abandonou. }\end{array}$

Juliano, em D. 41, 7, 6, sob outra perspectiva, nega-o de modo absoluto, justificando que a falsa existimatio, isto é, a boa-fé, jamais poderá substituir o real abandono:
"Nemo potest pro derelicto usucapere, qui falso existimaverit rem pro derelicto habitam esse".
Não é possível usucapir pro derelicto quem erroneamente acredita que a coisa tenha sido abandonada.

No fragmento seguinte, ele reitera o princípio, citando o exemplo das coisas lançadas de um naufrágio: 
D. $41,7,7$ :

"Si quis merces ex nave iactatas invenisset, num ideo usucapere non possit, quia non viderentur derelictae, quaeritur. Sed verius est eum pro derelicto usucapere non posse".
Se alguém tivesse encontrado algumas mercadorias lançadas para fora do navio, $<$ deve-se> perguntar se pode usucapir-las, já que não se consideram abandonadas e é mais verdadeiro que não se pode usucapir-las "pro derelicto".

Da mesma maneira decidia Javoleno, também citando o exemplo das coisas perdidas no mar ou lançadas de um navio para tornar mais a carga mais leve:

D. 41, 2, 21,1:

"Quod ex naufragio expulsum est, usucapi non potest, quoniam non est in derelicto, sed in deperdito".

D. 41, 2, 21,2:

"Idem iuris esse existimo in his rebus, quae iactae sunt: quoniam non potest videri id pro derelicto habitum, quod salutis causa interim dimissum est”.
Aquilo que de um naufrágio se lança ao mar, não se pode usucapir, pois não está abandonado, mas sim, perdido.
Creio que o mesmo vale a respeito das coisas que tenham sido alijadas, pois não se pode considerar abandonado aquilo que se lançou para salvar a vida.

Da leitura dos fragmentos, no que tange ao título putativo, Javoleno, Juliano e Paulo de forma uníssona tendem a negá-lo.

Ademais, obseva P. BONFANTE ${ }^{24}$ que os outros textos não trazem conteúdo que nos permita concluir o contrário.

Conclui o autor em relação ao título pro derelicto, que a sua principal ocorrência no direito clássico decorre do abandono de res mancipi utilizada a domino e no direito justinianeu um sistema análogo foi aplicado aos bens imóveis.

\footnotetext{
${ }^{23}$ Le singole cit. (nota 10 supra), p. 555

${ }^{24}$ Le singole cit. (nota 10 supra), p. 555
} 


\section{Título pro soluto}

A solutio (ou pagamento) consiste na satisfação natural da obrigação e no rompimento do vínculo obrigatório entre as partes, o que se dá mediante a exata prestação do objeto devido $^{25}$.

O título pro soluto se faz presente, necessariamente, naquelas situações em que a solutio de uma relação jurídica é direcionada à transmissão da propriedade ${ }^{26}$.

Segundo P. BONFANTE ${ }^{27}$, o estudo da solutio enquanto iusta causa de usucapião demonstra-se relevante apenas quando o objeto da obrigação é um dare.

Isso porque, para que seja satisfeita a obrigação, exige-se a alienação de um direito sobre uma coisa em favor do credor, constituindo, para ele, a iusta causa, ou, em outras palavras, a justificação decorrente da aquisição.

Para o citado autor, esta subordinação a um vínculo obrigatório (dare) é que fundamenta, determina e dá valor às variadas espécies de solutio, pois se esse vínculo obrigatório não é reconhecido pela lei, ou seja, se ele é iniustus, isso acarretaria a nulidade da solutio e, por conseguinte, ela não seria admitida como iusta causa.

A consequência desse vício será a impossibilidade de transferência da propriedade com exceção da res mancipi, pois nela se pode supor que o domínio seja transmitido diante do rigor formal da mancipatio -, mesmo que o devedor dê uma coisa que lhe pertença em cumprimento à obrigação.

Como exemplos, P. Bonfante ${ }^{28}$ cita o pagamento com base em um mútuo, o qual é vedado por Macedoniano, a satisfação de uma promessa de doar entre cônjuges, e o pagamento efetuado pela mulher contra os termos do senatusconsulto Veleiano, que não é meio apto a justificar a passagem da propriedade e, se a tradição não ocorreu por efeito da consumptio, pode-se intentar a rei vindicatio.

Todavia, adverte o citado autor que se não for conferido ao pagamento o caráter de um ato ilegal, isto é, se a causa remota não for proibida pela lei, a existência de fato ou inexistência da causa será irrelevante para a passagem da propriedade.

\footnotetext{
${ }^{25}$ Le singole cit. (nota 10 supra), p. 555.

${ }^{26}$ V. SCIAlOJA, Teoria della proprietà, II, Roma, Sampaolesi, 1929, p. 123.

${ }^{27}$ Le singole cit. (nota 10 supra), p. 555.

${ }^{28}$ Le singole cit. (nota 10 supra), p. 555.
} 
Sob esse aspecto, a causa real é totalmente independente da causa obrigatória.

Por outro lado, observa P. BONFANTE ${ }^{29}$ que pelo fato da lei reconhecer a validade imediata de alguma aquisição jurídica, ela não prevê se esta aquisição deve resultar de uma série de causas interdependentes, pois a lei nunca se referido sobre a justificação absoluta desta aquisição, tampouco sobre a garantia de inexistência de lesão à outra parte.

Assim, tanto no campo dos direitos reais, como no campo das obrigações, a causa se reflete sobre a relação mais próxima e direta.

Disso se extrai a razão pela qual o direito às vezes leva ao uso de formas abstratas, diante das quais a causa real desaparece completamente, ou vem tratada como causa remota.

Em decorrência disso, assevera o autor que contra cada possível distorção, direito assegura remédios nas condictiones, em outras ações especiais, e também nas exceptiones.

Essa dedução não dá espaço para a discussão em relação à traditio, pois nela a identificação da causa real acontece quase que instintivamente.

Aduz o autor que "qualunque rapporto è di regola atto a giustificare la volontà di trasmettere il dominio, e pertanto gli è solo a questa volontà, che si ha l'occhio, e la causa resta quase nell'ombra, 30 .

Por essa razão, o reconhecimento da vontade de alienar por parte do verdadeiro proprietário é suficiente para evitar o exame mais detalhado da causa.

O que se conclui é que um dado de conteúdo subjetivo - no caso, a boa-fé na manifestação da vontade de alienar - acaba projetando o exame da causa como atividade menos relevante.

Por isso, P. Bonfante sustenta que estabelecer uma relação entre este conceito e o usucapião e, concomitantemente, estando ele ligado a uma relação obrigatória, determinar a sua causa pode se tornar tarefa difícil.

A causa solvendi é considerada iusta causa para o usucapião quando a passagem imediata do domínio não acontece, especialmente, quando o objeto da aquisição é uma res aliena, ou uma res mancipi que, no ato da aquisição, não foram observadas as devidas

\footnotetext{
${ }^{29}$ Le singole cit. (nota 10 supra), p. 556.

${ }^{30}$ P. BONFANTE, Le singole cit. (nota 10 supra), p. 557.
} 
formalidades ${ }^{31}$.

O autor cita Juliano, (D. 41, 3, 33, 3) em um caso que, em alguns momentos, de fato, poderia-se justificar a existência da dúvida, pois a designação pro soluto ainda não era conhecida: "is a quo ex stipulatu fundum petere volebam, cedendo mihi possessione, si solvendi causa id facerit, eo ipso efficiet, ut fundum longo tempore capiam ${ }^{32}$,.

Assinala o mencionado autor que as únicas hipóteses em que se verifica a denominação pro soluto estão em Paulo e Hermogeniano. A partir de Juliano, essa espécie de causa não deveria ter sido dogmaticamente tratada pela traditio, mas sim pelo termo genérico pro suo.

No pensamento de Juliano o usucapião do imóvel (itálico) ocorria porque, no caso, foi cedida tão somente a posse, e a propriedade, ante a ausência dos modos formais, não havia sido transmitida.

Ressalta P. BONFANTE ${ }^{33}$ que não existe no caso citado por Juliano qualquer indício que nos permita concluir que a res fosse aliena, mesmo que no texto original se observe "in iure cedere possessionem", a invés de "cedere possessione”.

No tema da solutio, merece atenção um texto de Pompônio (D. 41, 10, 3) referente ao título pro suo, o qual traz algumas particularidades:

$\begin{array}{ll}\begin{array}{l}\text { "Hominem, quem ex stipulatione te mihi } \\ \text { debere falso existimabas, tradidisti mihi: si }\end{array} & \begin{array}{l}\text { Entregaste-me um escravo que você, } \\ \text { erroneamente, acreditava que devia em }\end{array} \\ \text { sciissem mihi nihil debere (deberi scr.), usu } & \text { virtude de estipulação; não poderei usucapir- } \\ \text { eum non campiam: quia (quod) si nescio, } & \text { lo se sei que <você> nada me devia, mas, se } \\ \text { verius est, ut usucapiam; quia ipsa traditio ex } & \text { eu não sei, é certo que poderei usucapir, pois a } \\ \text { iusta causa, quam veram esse existimo, } & \text { mesma tradição por justa causa, a qual creio } \\ \text { sufficit ad efficiendum, ut id, quod mihi } & \text { verdadeira, basta para fazer-me possuir "como } \\ \text { traditum est, pro meo possideam; et ita } & \text { próprio" o que entregaste-me; assim escreveu } \\ \text { Neratius scripsit, idque verum puto". } & \text { Nerácio e eu considero como verdadeiro. }\end{array}$

\footnotetext{
${ }^{31}$ P. BONFANTE, Le singole cit. (nota 10 supra), p. 557.

${ }^{32}$ Também aquele de quem eu queria reclamar um imóvel por causa de estipulação, se me cede sua posse com
} 
Assevera P. BOnfante ${ }^{34}$ que Pompônio, em explícita referência à Nerácio, inclina-se a dar maior peso à boa-fé do que à iusta causa.

Isso pode ser observado, através da forma de se expressar do próprio Pompônio: "traditio ex causa, quam veram esse existimo".

Realmente, o texto parece conduzir à conclusão que com base em um título putativo o jurisconsulto pretende reconhecer o usucapião, especialmente na fattispecie onde afirma “considerar verdadeira a tradição por justa causa", para que então esteja o possuidor autorizado a possuir "como próprio".

No entanto, para P. BONFANTE, aqueles que defendem doutrinariamente essa opinião, equivocam-se e deixam transparecer que não compreenderam corretamente a essência da designação pro suo.

Ademais, nota o citado autor que muitos escritores acabam cometendo um equívoco ainda mais grave, sustentando que a solutio é um título necessariamente putativo ${ }^{35}$.

Sobre essa posição da doutrina, o mencionado estudioso afirma que ela não é aceitável, pois a causa remota (o negócio propriamente dito) não pode exigir para o usucapião mais do que aquilo que se exige para a traditio (causa próxima).

Caso queira-se afirmar que na hipótese trazida por Pompônio estaria ausente a iusta causa usucapionis, necessariamente, como desdobramento lógico, também estaria ausente a iusta causa traditionis.

Contudo, esclarece P. BONFANTE que isso não seria possível.

Do mesmo modo que a traditio exige justa causa para transmitir a propriedade - uma vez que o modo de tradição é a própria traditio ex iusta causa -, é certo que em uma situação como aquela citada por Pompônio, a propriedade é transmitida e o devedor não pode tentar reaver a coisa, senão mediante a conditio indebiti ${ }^{36}$.

Paulo, jurisconsulto que assumidamente é avesso ao título putativo, por seu turno, admite o título pro soluto.

\footnotetext{
intenção de pagamento, faz com isso que eu possa adquirir a propriedade do imóvel pela posse de longo tempo.

${ }^{33}$ Le singole cit. (nota 10 supra), p. 558.

${ }^{34}$ P. BONFANTE, Le singole cit. (nota 10 supra), p. 559.

${ }^{35} \mathrm{O}$ autor refere-se ao pensamento de E. BöcKING, Pand., § 146, p. 94, nt. 37; T. SCHIRMER, Z. für C. R. u. Pr., N. F., 16, p. 49; H. FitTing, Archiv, LII, pp. 6-9; I. AliBRAndi, Possesso, p. 118, cit. por P. Bonfante, Le singole cit. (nota 10 supra), p. 559.

${ }^{36}$ P. BONFANTE, Le singole cit. (nota 10 supra), p. 559.
} 
A partir da análise do texto, conclui P. BONFANTE que não parece que o fragmento tenha um significado que represente um grande desafio interpretativo.

O autor reconhece a existência de uma certa oscilação, por parte do jurisconsulto, sobre o caráter verdadeiro ou putativo desta iusta causa.

Entretanto, ele entende que esta perplexidade decorre da natureza da solutio, a qual é "colorita e quasi sopressa dalla causa remota, e dal non essersi forse ancora svolta e fissata nelle mente, mercè la designazione especifica "pro soluto", quale "iusta causa" dell'usucapione, ${ }^{, 37}$.

Outrossim, o autor nota que Pompônio se mostra muito mais exigente acerca da boa-fé do possuidor do que da existência de um título, logo, para o jurisconsulto, pareceria indiferente o fato do título ser real ou putativo.

Conclui-se, portanto, que a discussão exposta no fragmento de Pompônio pauta-se no campo da boa-fé, e não do título.

Em relação à traditio, o autor chegou à mesma conclusão.

O fato do possuidor citado por Pompônio possuir pro meo, não significa, em nenhuma hipótese, a confissão da existência do título putativo.

Nessa situação, o termo pro soluto está ausente, pois ainda não era conhecido, por isso Pompônio faz uso do termo genérico pro suo.

Para P. BONFANTE ${ }^{38}$, a situação narrada por Pompônio enfrenta a seguinte indagação de ordem lógica: considerando que a aquisição imediata foi válida e eficaz, onde tudo se procedeu regularmente, como se poderia negar o usucapião?

Essa questão preocupa-se, na verdade, com o fato de que com a tradição, mesmo feita a domino, tratando-se de res mancipi, não se transmitiria outra coisa além da posse.

Ademais, o próprio Pompônio fez com que a questão permanecesse agitada entre os jurisconsultos.

Mas o problema não guardaria relação com o usucapião ou com o motivo pelo qual ele se fez necessário, tampouco se preocuparia com o fato da coisa pertencer ao devedor ou a terceiro.

\footnotetext{
${ }^{37}$ Le singole cit. (nota 10 supra), p. 559-560.

${ }^{38}$ Le singole cit. (nota 10 supra), p. 560.
} 
P. BONFANTE ${ }^{39}$ sustenta que nem ele próprio deixará de acreditar que, para que a tradição não seja considerada como modo de aquisição do domínio no pensamento de Pompônio - de resto, em geral, o caráter do modo de aquisição da tradição é pelo direito clássico secundário -, a ipsa traditio deve-se demonstrar designação suficiente do negócio que contém a exigida iusta causa próxima.

Assim, para o autor, nem pela forma e nem pela substância o fragmento de Pompônio apresenta algo de extraordinário.

Tampouco em matéria de usucapião, quando se cogita a tão incriminada frase "traditio ex iusta causa quam veram esse existimo" esse texto oferece um grande desafio interpretativo.

Em outra linha, para L. VACCA ${ }^{40}$ o fragmento de Pompônio trata do caso de uma imissão na posse decorrente de uma traditio "ex iusta causa quam veram esse existimo".

No texto, esse domínio proveniente da existimatio é legitimado pelo erro da outra parte, e aquele que recebe a coisa em tradição acredita falsamente que é credor daquela obrigação.

A partir dessa situação, a autora conclui que essa usucapio é justificada por um elemento objetivo, o qual é suficiente para a configuração da possessio pro suo: a imissão na posse resultante da traditio.

\subsection{O título pro soluto e sua correlação com o título pro suo}

Em temas como aquisição imediata e usucapião, P. BONFANTE afirma que esta é, talvez, a espécie mais documentada das Pandectas.

A designação pro soluto é encontrada inicialmente em Paulo (D. 41, 3, 48, in fine).

“(...) nec potest pro emptore usucapere, qui non emit, nec pro soluto, sicut in ceteris contractibus",

\footnotetext{
“ (...) não se pode usucapir pro emptore aquele que não comprou, nem sequer pro soluto, como acontece nos demais contratos.
}

No referido fragmento, a preocupação de Paulo é em relação à exceção constituída pela compra e venda, onde não se faz suficiente a solutio, e também não se admite usucapião

\footnotetext{
${ }^{39}$ Le singole cit. (nota 10 supra), p. 560.
} 
pro soluto, como se faz nos demais contratos.

Oberva P. BONFANTE ${ }^{41}$ que provavelmente, por ter tratado da questão da iusta causa com um rigor mais sólido, Paulo teria sido compelido a cuidar de forma mais atenta de algumas causas que ainda não tinham sido analisadas e, consequentemente, teria atribuído a elas a condição de verdadeiros títulos de usucapião.

Acrescenta o autor que algo ainda mais ousado Paulo decidiu no caso da escrava, em D. $41,3,4,5$.

Enquanto Juliano e Ulpiano estendem os efeitos do título da mãe para salvar o usucapião, Paulo, por seu turno, reconheceu naquele caso um título novo, o pro suo.

Paulo cita com naturalidade o usucapião com base no pagamento em outros textos: D. 41, 4, 2 pr. (do mesmo teor do citado fragmento) e D. 41, 3, 15, 3:

\begin{abstract}
“ Si ex testamento vel ex stipulatu res debita nobis tradatur, eius temporis existimationem nostram intuendam, quo traditur, quia concessum est stipulari rem etiam quae promissoris non sit.".
\end{abstract}

\begin{abstract}
Se nos entrega <aquilo> que nos deve por testamento ou estipulação, deve-se atender < diante de nossa boa-fé> ao momento da tradição, pois também é lícito estipular uma coisa que não pertence ao promitente.
\end{abstract}

Paulo inclui a solvendi causa entre as iustae causae da ação Publiciana em D. 6, 2, 4 (vel solvendi causa) e acena, enfim, ao usucapião, com base em uma datio in solitum em D. 41, 3, 4, 17 e em D. 46, 3, 60, a qual é extraída dos livros ad Plautium.

D. $41,3,4,17$ :

"Sed et si, ut servum meum manumitterem, alius mihi furtivam ancillam dederit eaque apud me conceperit et pepererit, usu me non capturum. Idemque fore etiam, si quis eam ancillam mecum permutasset aut in solutum dedisset, item si donasset".
Mas, se para que eu manumitisse um escravo meu, outro me tiver dado uma escrava furtada e aquela escrava tivesse concebido e dado a luz a filho estando em meu poder, não poderei usucapir esse filho. O mesmo aconteceria se alguém tivesse me dado tal escrava em permuta ou em pagamento ou se tivesse me doado.

\footnotetext{
40 "Iusta causa" e "bona fides" cit. (nt. 12 supra), p. 1.963.

${ }^{41}$ Le singole cit. (nota 10 supra), p. 561.
} 
Todavia, para P. BONFANTE ${ }^{42}$, o enunciado geral e a mais perfeita determinação do título pro soluto se encontra em Hermogeniano, D. 41, 3, 46:

"Pro soluto usucapit, qui rem debiti causa recipit: et non tantum quod debetur, sed et quodlibet pro debito solutum hoc titulo usucapi potest”.
É possível usucapir pro soluto aquelas coisas recebidas por causa de dívida e não somente o que se devia, mas se pode usucapir por este título tudo aquilo que se dá em pagamento de uma dívida.

Segundo o autor, em relação a esse fragmento, o último inciso provavelmente refere-se à datio in solitum, porém, quanto ao restante, ainda que parte da doutrina diga o contrário, não se tem dúvida - especialmente diante do caminho oferecido por Pompônio -, que até mesmo o pagamento de uma obrigação inexistente é um título real.

Conclui o autor que em relação à modalidade pro soluto, a solutio ou causa solvendi é uma modalidade de aquisição, tanto para a tradição como para o usucapião.

É irrelevante se a obrigação precedente tem existência real, o que se exige é que ela não seja injusta.

P. BONFANTE ${ }^{43}$ não descarta a possibilidade de que, entre os jurisconsultos, tenha havido controvérsias sobre o real valor desta iusta causa de usucapião, mas quanto a isso não existe nas fontes evidência alguma que comprove a afirmação.

Conclui o estudioso que parece que até mesmo os defensores do título putativo tenham se excedido algumas vezes na interpretação, admitindo, por exemplo, o pagamento efetuado por pessoa incapaz ou um pagamento completamente imaginário como iusta causa do usucapião.

As demais considerações sobre o título pro soluto serão desenvolvidas em correlação à modalidade pro emptore neste trabalho.

\section{Título pro donato}

\footnotetext{
${ }^{42}$ Le singole cit. (nota 10 supra), p. 562.

${ }^{43}$ Le singole cit. (nota 10 supra), p. 562.
} 
A doação é definida por P. BONFANTE ${ }^{44}$ como a renúncia absoluta e perpétua de um direito patrimonial em favor de uma determinada pessoa, sem nenhuma contrapartida.

L. VACCA ${ }^{45}$ sustenta que no período clássico a doação podia constituir a causa de vários negócios jurídicos, tanto de caráter obrigatório como real, mas não se constituiria em negócio autônomo.

A exemplo da renúncia propriamente dita, a doação pode ser interpretada quase como causa gratuita, isso porque, conforme P. BONFANTE ${ }^{46}$, ambas não exigem contraprestação, salvo em relação ao fato de que a primeira possui caráter temporário.

Acrescenta o autor que a causa donandi não pode ser inferida de uma relação concreta e visível entre as partes, ela concentra-se toda no animus donandi-considerando a gratuidade ou inexistência de contraprestação -, isto é, sem que se exija qualquer coisa em troca, o doador manifesta a sua vontade de abandonar o direito em favor de alguém.

A doação é causa genérica e pode ser tanto real como obrigatória (obrigação ou promessa de doar).

Dentre as formas de doação, aquela que é relevante ao estudo das iustae causae e do título putativo é a doação com efeitos reais.

Para P. BONFANTE ${ }^{47}$, quando se tem em relação à solutio, como justificativa ou causa da aquisição real uma doação obrigatória, seja via usucapião ou mediante tradição, não se deve levar em consideração a existência ou não de uma promessa de doar.

Em Paulo (D. 41, 6, 1) observa-se a exigência do título verdadeiro para fim de iusta causa: "nec sufficit opinari, sed et donatum esse oportet 48 " e citando o exemplo da doação feita pelo pai ao filho in potestate, prossegue Paulo no $\S 1^{\mathrm{o}}$ :

"Si pater filio quem in potestate habet donet, deinde decedat, filius pro donato non capiet usu, quoniam nulla donatio fuit".
Se um pai doa algo a um filho que esteja abaixo de sua potestade e logo <o pai> morre, o filho não poderá usucapir pro donato, porque não houve doação alguma.

Segundo P. Bonfante, a clareza do exemplo de Paulo faz com que até mesmo os

\footnotetext{
${ }^{44}$ Le singole cit. (nota 10 supra), p. 563.

${ }^{45}$ L. VACCA, La strutura originaria dell'usucapione, in EDI, XLV, p. 1006.

${ }^{46}$ Le singole cit. (nota 10 supra), p. 563.

${ }^{47}$ Le singole cit. (nota 10 supra), p. 563.
} 
defensores do título putativo se vejam compelidos a concordar com ele.

Em nenhuma hipótese poderia o filho crer que a doação fosse válida, sem que se incorresse em um gravíssimo erro de direito, pois os defensores do título putativo entendem que a boa-fé e o erro podem substituir a iusta causa usucapionis em toda e qualquer situação, mas nunca em relação ao erro de direito e ao erro inescusável ${ }^{49}$.

Ressalta o autor que o princípio da escusabilidade é aplicado ao usucapião somente em textos ou autores que admitem o título putativo ${ }^{50}$.

Até mesmo Pompônio, apontado por alguns como defensor do título putativo, posiciona-se no sentido da exigência do título verdadeiro.

Para ele, a filha que recebeu uma doação do pai e é deserdada, somente usucapirá no momento em que for feita a ratihabitio pelo herdeiro.

Exemplifica P. BONFANTE ${ }^{51}$ citando o caso do paterfamilias que não tomou de volta pra si o pecúlio no ato da emancipação do filho ou da manumissão do escravo.

Ter-se-ia, na hipótese, uma verdadeira doação, porém, juridicamente, este domínio era apenas de fato.

A particularidade consiste somente na espécie de traditio brevi manu, e em uma razoável presunção do animus donandi.

O que se observa in casu, é que a vontade do paterfamilias foi de renunciar o pecúlio em favor do filho e do escravo e, nesse caso, não há qualquer lei que disponha que esta vontade não seja válida.

Ademais, conforme o mesmo autor, o que importa nesta hipótese é que exista uma iusta causa possidendi reconhecível e inegável.

Portanto, Papiniano, sem se preocupar tanto em determinar se a relação constituía uma doação, ora diz que o escravo possui "ex iusta causa", ora diz que o filho emancipado usucape "pro donato vel pro suo"

Assevera P. BONFANTE que não obstante tal constatação, o que nos importa é que ele

\footnotetext{
${ }^{48}$ Não é suficiente a crença, é necessário que tenha havido a doação.

${ }^{49}$ P. BONFANTE, Le singole cit. (nota 10 supra), p. 563-564.

${ }^{50}$ P. BONFANTE, Essenza della “bona fides" e suo rapporto colla teórica dell'errore, in BIDR, p. 85.

${ }^{51}$ Le singole cit. (nota 10 supra), p. 564.

${ }^{52}$ Frag. Vat. 260, 261
} 
admite a existência da vontade de renunciar ao pecúlio em favor do filho ou do escravo ${ }^{53}$.

Todavia, caso o escravo tenha sido libertado por testamento, ele perde o pecúlio se não o tiver recebido em legado.

Em síntese, a donatio inter virum et uxorem não é iusta causa para a tradição, portanto, em primeira análise, não deveria ser para usucapião.

É isto que afirma Paulo, em D. 41, 6, 1, 2: "Si inter virum et uxorem donatio facta sit cessat usucapio $^{54 ",}$.

Se acontecesse um divórcio, o autor salienta que Cássio nos oferece a solução, no mesmo fragmento.

Esse jurisconsulto afirmava que o usucapião não poderia acontecer mesmo após o divórcio, haja vista que a mulher já possui o bem por uma causa iniusta, logo, tendo sido realizado divórcio, a mulher não pode mudar a causa da própria posse $\mathrm{e}^{55}$.

Todavia, não seria assim se o marido tivesse concedido o direito à mulher de reter a coisa após o divórcio.

Segundo o autor, o raciocínio é demasiadamente simples e absolutamente semelhante à doação feita pelo paterfamilias ao seu filiusfamilias e confirmada pelo herdeiro.

Salienta o romanista que "lo spirito fine dell'equitas, che induceva i giureconsulti romani a ridurre, mercê un'ampia libertà d'interpretazione, ne' limiti più prossimi alla "ratio"della legge le norme e gli istituti non confondentisi colla "ratio" istessa,56.

Assim, por maior que seja a margem de interpretação, a equitas determinava o limite de interpretação.

No caso em exame, o que levou os jurisconsultos romanos a admitir o usucapião foi o fato de que o cônjuge doador não se tornou mais pobre em decorrência da alienação efetuada.

Este entendimento é encontrado em Trebácio, cuja opinião foi acolhida e tratada por Pompônio, em D. 41, 6, 3:

"Si vir uxori vel uxor viro donaverit, si Se o marido tivesse doado algo à mulher, ou

\footnotetext{
${ }^{53}$ P. BONFANTE, Le singole cit. (nota 10 supra), p. 564.

${ }^{54}$ Cessa o usucapião nas doações entre cônjuges.

${ }^{55}$ P. BONFANTE, Le singole cit. (nota 10 supra), p. 565.

${ }^{56} \mathrm{P}$. BONFANTE, Le singole cit. (nota 10 supra), p. 565.
} 
aliena, res donata fuerit, verum est, quod Trebacius putabat, si pauperior is qui donassi non fieret, usucapionem possidenti procedere". vice-e-versa, e a coisa doada fosse alheia, é verdade o que acreditava Trebácio de que, se o doador não diminuiu com ela seu patrimônio, procede o usucapião em favor do donatário.

A mesma razão de proibição P. BONFANTE ${ }^{57}$ identifica em um fragmento de Terêncio Clemente, em D. 24, 1, 25:

\begin{abstract}
"Sed et si constante matrimonio res aliena uxori a marito donata fuerit, dicendum est confestim ad usucapionem eius uxorem admitti, quia et si non mortis causa donaverat ei, non impediretur usucapio. Nam ius constitutum ad eas donationes pertinet, ex quibus et locupletior mulier et pauperior maritus in suis rebus fit: itaque licet mortis causa donatio interveniat, quasi inter extraneas personas fieri intellegenda est in ea re, quae quia aliena est usucapi potest”.
\end{abstract}

Se o marido, durante o matrimônio, tivesse doado à sua mulher uma coisa alheia, deve ser dito que a sua mulher começa a usucapir desde o primeiro momento, pois, ainda que a doação não tivesse sido por causa da morte, não se impedirá o usucapião. Já que a proibição que estabelece o direito se refere às doações pelas quais a mulher aumenta o seu patrimônio e o marido diminui o seu; assim, pois, ainda que a doação <não> seja a causa da morte, deve se entender que se faz como entre pessoas estranhas entre si, quando a coisa se pode usucapir por ser alheia.

Como se observa do texto ficaria excluído o usucapião na hipótese do marido doar coisa possuída ad usucapionem por ele mesmo.

Observa P. BONFANTE ${ }^{58}$ que esse raciocínio é negado por H. FitTinG ${ }^{59}$, mas este autor teria admitido que a decisão de aliena res ... si pauperior ...” não representa uma condição dúplice.

Verifica ainda que, segundo Pompônio, seguindo a linha de Trebácio, onde observa que o doador não diminuiu do seu patrimônio com a doação, faz com que permaneça inatacável o entendimento de SAVIGNY, no sentido de que a possessio ad usucapionem é um direito.

\footnotetext{
${ }_{58}^{57}$ Le singole cit. (nota 10 supra), p. 566.

${ }^{58}$ Le singole cit. (nota 10 supra), p. 566.
} 
Todavia, nada impediria que um dos cônjuges viesse a empobrecer e o outro enriquecer através do prejuízo do primeiro, mas, se isso ocorresse, não seria em decorrência da doação feita um ao outro.

Ainda assim, acentua P. BONFANTE ${ }^{60}$ que não seria o caso de se aplicar a proibição da doação, especialmente porque, ao que se observa do texto, tudo se procedeu em boa-fé, além disso, a interpretação do jurisconsulto nesse caso não foi realizada de modo ilimitado.

Se a hipótese fosse submetida à análise de um jurisconsulto moderno, ele também não poderia decidir de modo diverso, pois a causa da posse não advém de donatio iniusta, e o enriquecimento de um e o prejuízo do outro não é diferente em qualquer usucapião que seja.

Isso é o que se observa no fragmento de Nerácio, D. 24, 1, 44, primeira parte:

"Si extraneus rem viri ignorans eius esse ignoranti uxori, ac ne viro quidem sciente eam suam esse, donaverit, mulier recte eam usucapiet".
Se um terceiro tivesse doado a uma mulher, que não o sabia, uma coisa que ele tampouco sabia que pertencia ao marido <dela>, sem saber tampouco isto, a mulher poderá usucapir justamente.

Levanta a dúvida P. BONFANTE ${ }^{61}$ acerca do que aconteceria, se antes do cumprimento do usucapião, o marido ou a mulher viesse a ter ciência do verdadeiro estado das coisas e se a mulher, por seu turno, viesse a saber da ciência do marido.

A resposta é encontrada no próprio Nerácio, em continuação ao mesmo fragmento:

"Sed si vir rescierit suam rem esse, priusquam usucapiatur, vindicareque eam poterit nec volet et hoc et mulier noverit, interrumpetur possessio, quia transiit in causam ab eo factae donationis. Ipsius mulieris scientia propius est, ut nullum adquisitioni dominii eius adferat impedimentum: non enim omnimodo uxores ex bonis virorum, sed ex causa donationis ab
Mas se o marido ficou sabendo que a coisa era sua antes do usucapião se consumar, porém, podendo reinvindicá-lo, não quis fazê-lo, e se isso tivesse sabido também a mulher, se interrompe o usucapião, em seguida começa a considerar-se como coisa doada pelo marido. Se é sabido tão somente pela mulher, isto não impede que ela chege a adquirir a propriedade, pois não está proibido em

\footnotetext{
${ }^{59}$ Archiv für Civ. Pr., 52, p. 115, cit por P. BONFANTE, Le singole cit. (nota 10 supra), p. 566.

${ }^{60}$ Le singole cit. (nota 10 supra), p. 567.

${ }^{61}$ Le singole cit. (nota 10 supra), p. 567-568.
} 
ipsis factae adquirere prohibitae sunt".

absoluto que as mulheres adquiram as coisas que pertencem a seus maridos, mesmo quando a causa é uma doação feita por eles.

Em síntese, nem a ciência superveniente do marido de que a coisa decorre do seu patrimônio, nem a ciência da própria mulher acerca da ciência do marido, não interrompem a posse e, tampouco, o usucapião.

Explica P. BONFANTE seu raciocínio: "non la del marito, perché non puó accadere che per essa muti, senza saputa e consenso del terzo donante e della donna, la causa per cui la donna già possedeva; non la scienza della moglie, perchè questa non fa che annientare la buona fede di lei, nè al decorso dell'usucapione si domanda una buona fede perpetua ${ }^{62}$ ",

Conforme o mesmo autor, se a mulher é consciente da ciência do marido e de seu propósito de renunciar à propriedade em benefício dela, deixando assim de reivindicá-la.

Além disso, se o marido e a mulher são conhecedores do estado da coisa, por consequência, a ciência e o consenso das duas partes acarretam a mudança da causa da posse, logo, essa causa será convertida em uma iniusta causa, sobre a qual não se pode usucapir, como também não se pode adquirir imediatamente.

Assevera, ainda, que além daquilo que no fragmento se fala, ou seja, da natureza especial do usucapião, deve se observar que na segunda hipótese, i.e, na doação feita por um filiusfamilias, o jurisconsulto apresenta pelos menos um título intrinsecamente viciado, senão, propriamente, um título imaginário.

\section{Título pro dote}

O dote apresenta na sua estrutura geral uma semelhança visível com a doação.

Assim, como a doação, o dote é uma causa genérica, isto é, o negócio jurídico (causa) que pode constituir tanto uma transferência de direitos sobre a coisa, como uma obrigação ou promessa de dotar ${ }^{63}$.

A exemplo da doação, a modalidade que interessa para o desenvolvimento do

\footnotetext{
${ }^{62}$ Le singole cit. (nota 10 supra), p. 568
} 
presente estudo é apenas o dote enquanto causa real.

Isso porque, conforme elucida P. BONFANTE ${ }^{64}$, assemelharia-e à solutio, caso tivéssemos uma promessa de dote precedente (promissio ou dictio dotis no direito clássico, pactum dotale no direito novo) como causa de aquisição do domínio, seja ele imediato ou por usucapião.

O autor salienta que o dote se distingue da doação em um requisito essencial: o dote não é causa gratuita.

A contrapartida do dote "ha un carattere cosi artificioso e quasi espirituale ${ }^{65 "}$ onde, se não fosse essa diferença fundamental, as semelhanças seriam suficientes para se presumir que o dote, na sua origem, não era outra coisa senão uma doação especial.

Diz o autor, que um requisito essencial para compreender a eficácia da causa dotal é a compreensão acerca da sua contrapartida obrigatória, que nada mais é que "sostenere $i$ pesi del matrimonio ${ }^{66 ",}$

Desse modo, o dote é uma prestação perpétua que acompanha toda a existência dos direitos e lhes afeta a natureza, assim, não pode ser entendido como uma contraprestação antecedente ou atual que se exaure em um só momento.

Portanto, os direitos decorrentes da causa dotis só existirão enquanto existir um casamento, assim, é impossível, por consequência, que o dote tenha alguma eficácia quando não se tem o casamento, seja como causa de aquisição imediata, seja como iusta causa para fins de usucapião.

Esclarece P. BONFANTE ${ }^{67}$ que é exigido é mais que uma causa remota, exige-se uma causa concomitante, pois aquilo que é transmitido ao marido através do dote não é, substancialmente, o direito comum de propriedade, mas um direito quase especial, uma propriedade específica, somente concebível com o acontecimento do casamento.

Essa constatação corresponde a um primeiro sinal daquilo que dizem os jurisconsultos romanos, porém, mais evidências podem ser encontradas nos textos.

Observa P. Bonfante ${ }^{68}$ que Ulpiano em D. 41, 9, 1, 3 e D. 41, 9, 1, 4, cita o usucapião "inter eos locum habet inter quos est matrimonium", e corrobora o entendimento

\footnotetext{
${ }^{63}$ P. BONFANTE, Le singole cit. (nota 10 supra), p. 569.

${ }^{64}$ Le singole cit. (nota 10 supra), p. 569-570.

${ }^{65} \mathrm{P}$. BONFANTE, Le singole cit. (nota 10 supra), p. 570.

${ }^{66} \mathrm{P}$. BONFANTE, Le singole cit. (nota 10 supra), p. 570.

${ }^{67}$ Le singole cit. (nota 10 supra), p. 570.
} 
de Cássio, de que o usucapião não transcorrerá se o casamento for desfeito.

Portanto, se o matrimonio não subsistir realmente, não ocorrerá o usucapião, todavia, se apenas supõe-se que ele exista, "si putavit maritus esse sibi matrimonium, cum non esset", aplica-se o mesmo entendimento "quia nulla dos sit".

Acompanhando a percepção de Juliano, Ulpiano, em D. 41, 9, 1, 2, sinaliza a hipótese do usucapião antes do casamento:

"Et primum de tempore videamus, quando pro dote quis usucapere possit, utrum post tempora nuptiarum an vero et ante nuptias. Est quaestio volgata, an sponsus possit (hoc est qui nondum maritus est) rem pro dote usucapere. Et Iulianus inquit, si sponsa sponso ea mente tradiderit res, ut non ante eius fieri vellet, quam nuptiae secutae sint, usu quoque capio cessabit: si tamen non evidenter id actum fuerit, credendum esse id agi Iulianus ait, ut statim res eius fiant et, si alienae sint, usucapi possint: quae sententia mihi probabilis videtur. Ante nuptias autem non pro dote usucapit, sed pro suo”.
Tratemos primeiramente de quando se pode usucapir pro dote: se depois de contrair o casamento ou já antes, <pois> é uma questão corrente se o noivo (isto é, aquele que marido não é) pode usucapir algo pro dote. E Juliano disse, se uma noiva tivesse entregado umas coisas ao noivo, com a intenção de que não se tornassem dele antes do casamento, tampouco se dará o usucapião; mas se não tivesse feito assim expressamente, disse Juliano, que deve se crer que <ela> queria que < as coisas > se tornassem dele imediatamente e que <ele> pode usucapir-las se forem alheias; opinião esta que me parece mais provável; mas antes do casamento não se usucape pro dote, mas pro suo.

Para P. BONFANTE ${ }^{69}$ a pedra fundamental do texto de Juliano é a parte final.

Em análise ao fragmento, o autor observou que se a dação é exercida com a intenção de que a propriedade seja passada ao noivo antes do casamento, portanto, não se tem, in casu, um verdadeiro dote, mas uma dação visando a realização de um fato futuro, o casamento.

Logo, uma vez cumprido esse fato, ocorrerá a conversão do objeto da dação em bem dotal, alterando assim a causa da posse.

Diante disso, considerando que a coisa dada pela mulher era coisa própria e ela foi passada imediatamente, antes do casamento, o mesmo entendimento seria aplicado se a coisa dada fosse de terceiro e, nesse caso, poderia igualmente cumprir-se o usucapião.

\footnotetext{
${ }^{68}$ Le singole cit. (nota 10 supra), p. 571.
} 
No entanto, acentua P. BONFANTE ${ }^{70}$ que o título do usucapião não é o dote, mas sim aquele que o jurisconsulto romano designa com a expressão genérica pro suo.

Quanto a isso, deve se esclarecer que o fato do título ser nomeado como pro suo, não significa que estejamos diante de um título putativo, mas sim que foi nomeado dessa forma porque não havia à disposição do jurisconsulto um nome distinto e específico para a causa.

Outro jurisconsulto que também reconhecia o usucapião antes do casamento era Paulo.

O que ele fez foi seguir o entendimento acerca da designação pro suo apresentado por Juliano na Frag. Vat. 111.

Segundo P. BONFANTE ${ }^{71}$, outra modalidade em que pode se verificar o dote é aquela em que o marido é responsável pela quantidade, e não pelo objeto dado.

Nesse caso, o dote é feito por estimação.

Tem-se então um negócio complexo: a venda do objeto e a consequente constituição do preço em dote.

Nessa situação, segundo o autor, a estimação e a venda estariam pendentes até a efetiva realização do casamento, ou estaria sujeita à condição de que ele viesse a acontecer.

Em decorrência do defeito da iusta causa, diz Paulo, em D. 41, 9, 2, que do mesmo modo que não se poderia adquirir, também não seria possível usucapir:

"Si aestimata res ante nuptias tradita sit, nec pro emptore, nec pro suo ante nuptias usucapietur".
Se foi entregue uma coisa antes do matrimônio por estimação, nem pro emptore e nem pro suo, antes do matrimônio se poderá usucapir.

O mesmo entendimento pode ser conferido, de forma mais abrangente no Frag. Vat. 111:

"L. Titius a Seia uxore sua inter cetera accepit aestimatum etiam Stichum puerum et eum possedit annis fere quattuor; quaero, an
L. Tício recebeu de sua esposa Seia, entre as coisas restantes, também o escravo Estico previamente estimado e o possuiu por cerca

\footnotetext{
${ }^{69}$ Le singole cit. (nota 10 supra), p. 571.

${ }^{70}$ Le singole cit. (nota 10 supra), p. 572.

${ }^{71}$ Le singole cit. (nota 10 supra), p. 572.
} 
eum usuceperit. Paulus respondit, si puer, de quo quaeritur, in furtivam causam non incidisset neque maritus sciens alienum in dotem accepisset, possuisse eum aestimatum in dotem datum post nuptias anno usucapi. Quamvis enim Iulianus et ante nuptias res dotis nomine traditas usucapi pro suo posse existimaverit et nos quoque idem probemus, tamen hoc tunc verum est, cum res dotales sunt. Cum vero aestimatae dantur, quoniam ex empto incipiunt possideri, ante nuptias pendente venditione, non prius usucapio sequi potest quam nuptiis secutis". de quatro anos; pergunto se eu o adquirirei por usucapião. Paulo respondeu que, se o escravo sobre o qual que se pergunta não tivesse incorrido em uma causa de furto, e o marido, conscientemente, não tivesse aceitado um dote de um estranho, teria sido possível que aquele, dado em dote depois de ser avaliado, fosse adquirido por usucapião um ano depois do matrimônio. Pois, mesmo que Juliano creia que as coisas transferidas a título de dote antes do casamento podem ser usucapidas pro suo e nós também aprovamos o mesmo, sem embargo, isto é verdade quando se trata de coisas dotais. Quando se dão, em troca, estimadas, posto que começa-se a possuir como consequência de uma compra, ao estar pendente a venda antes do matrimônio, não se pode seguir o usucapião até que se tenha seguido ao matrimônio.

O texto de Paulo pode ser confrontado com o texto de Próculo (D. 23, 3, 67), no qual a figura especial designada como pro suo, segundo P. BonfANTE ${ }^{72}$, de certo modo esbarra no título putativo:

“Proculus Nepoti suo salutem. Ancilla quae nupsit dotisque nomine pecuniam viro tradidit, sive sciat se ancillam esse sive ignoret, non poterit eam pecuniam viri facere eaque nihilo minus mansit eius cuius fuerat antequam eo nomine viro traderetur, nisi forte usucapta est. Nec postea quam apud eundem virum libera facta est, eius pecuniae causam mutare potuit. Itaque nec facto quidem
Próculo saúda seu amigo Nepoti. A escrava que se casou e entregou em dote ao seu marido uma certa quantia, tanto se sabe que é escrava como se o ignora, não poderá fazer do marido esta quantia, a qual continua pertencendo ao mesmo de quem era antes de que se entregasse em dote ao marido, a não ser que o marido a tenha usucapido; mesmo depois de libertada a escrava que tivesse

\footnotetext{
${ }^{72}$ Le singole cit. (nota 10 supra), p. 573
} 
divortio aut dotis iure aut per condictionem repetere recte potest, sed is cuius pecunia est recte vindicat eam. Quod si vir eam pecuniam pro suo possidendo usucepit, scilicet quia existimavit mulierem liberam esse, propius est, ut existimem eum lucrifecisse, utique si, antequam matrimonium esse inciperet, usucepit. Et in eadem opinione sum, si quid ex ea pecunia paravit, antequam ea dos fieret, ita, ut nec possideat eam nec dolo fecerit, quo minus eam possideret". seguido com o mesmo marido não poderá mudar a situação daquela quantia; assim, pois, tampouco poderá reclamá-la depois do divórcio, nem por direito de dote nem pela condictio, mas pode reivindiar a quantia quem for seu proprietário. Mas se o marido possuiu pro suo, a usucapirá, isto é, porque acreditava que a mulher era livre, talvez dirá que a fez sua; entende-se o usucapião antes de iniciar o matrimônio; eu entendo o mesmo, se comprou alguma coisa com esta quantia antes que se constituísse em dote, de modo que não a possua nem tenha agido com dolo para deixar de possuí-la.

O fragmento refere-se ao caso de uma escrava que, casando-se com um homem livre, constitui a ele uma soma de dinheiro como dote, logo.

Nesse caso não há nenhum dote, e nenhum evento poderá alterar a situação das coisas.

Analisando o texto, conclui o autor que merecem destaque os trechos onde se afirma que a soma de dinheiro permanece com a mulher ("eius cuius fuerat antequam eo nomine viro traderetur”), por isso, a tradição é ineficaz ( "nisi forte usucapta est”).

Assevera P. BONFANTE ${ }^{73}$ que se o fragmento parasse naquele ponto seria ainda mais complicado, pois o casamento entre escravo e homem livre é um ato que o direito não pode admitir, além disso, a relação dotal é inconcebível.

Diante de uma situação como essa, o usucapião não seria baseado em um título imaginário, mas em um título impossível.

Próculo, por sua vez, afirma que o marido pode usucapir a soma, possuindo-a "pro suo”, porém, antes que aconteça o casamento e que o dinheiro se torne dote.

Nesse caso, a causa do usucapião é uma espécie de negócio inominado.

Assim, segundo o citado autor, é irrelevante o fato do casamento ser ou não possível

\footnotetext{
${ }^{73}$ Le singole cit. (nota 10 supra), p. 574
} 
de acontecer, pois ele, em substância, não representa nada além da contraprestação do dote realizado, logo, em analogia, independentemente da execução da outra parte, o dote é válido.

Portanto, se fosse reconhecida a incapacidade da mulher, ainda que ela fosse colocada em liberdade para se casar com outro homem, a tradição seria válida e esta aquisição seria resolúvel apenas por intermédio da condictio, de tal modo que se a coisa transmitida fosse alheia, até mesmo um defensor do título verdadeiro deveria admitir o usucapião.

Ressalta P. BONFANTE ${ }^{74}$ que Próculo não denominaria o título como pro suo, apenas porque se tem na hipótese um título putativo.

O autor conclui que a diferença das espécies trazidas por Juliano, Paulo e Ulpiano em relação ao título pro suo diante de Próculo, considerando que deriva da pessoa incapaz de possuir e de alienar, apresenta, na verdade, um título putativo.

Entretanto, não obstante as evidências extraídas do texto, o que se verifica é que se está diante de um título viciado, e não imaginário.

Assevera P. BONFANTE que assim como o fragmento de Nerácio sobre doação, que a doutrina induz o reconhecimento geral dos títulos pelo direito justinianeu na categoria de iusta causa usucapionis, a partir dele, não se pode concluir a admissão do título puramente imaginário.

Em relação ao texto de Próculo, L. VACCA ${ }^{75}$ sugere que da leitura do fragmento, podese afirmar que a posse de boa-fé do marido é suficiente ao usucapião, pois, neste caso, o usucapião é admitido segundo a análise da escusabilidade do erro, logo, exclui-se o título pro dote e reconhece-se, no caso, o título pro suo.

Para a autora, portanto, a boa-fé exclui o título se o usucapião foi cumprido com base unicamente nela, assim, não havendo título, consequentemente, não há que se falar se ele é real ou putativo.

\footnotetext{
${ }^{74}$ Le singole cit. (nota 10 supra), p. 575.

75 "Iusta causa” e "bona fides" cit. (nt. 12 supra), p. 1.978-1.979.
} 


\section{Título pro emptore}

Para P. BONFANTE ${ }^{76}$ a compra e venda (ou título pro emptore) é a mais importante iusta causa e a primeira na ordem histórica.

Sustenta L. VACCA ${ }^{77}$ que esta causa de aquisição é, provavelmente, a que contou com a maior elaboração por parte da jurisprudência romana e também pela doutrina sucessiva.

Ademais, nessa modalidade de usucapio observa-se com mais clareza o entrelaçamento entre a iusta causa traditionis e iusta causa usucapionis de um lado e a iusta causa e bona fides de outro.

A compra e venda refere-se a uma causa que pode justificar tanto a aquisição de direitos reais, como a constituição de direitos de obrigações, ou seja, a doação e o dote.

Segundo P. BONFANTE ${ }^{78}$, a jurisprudência prática reconhece uma compra e venda, tanto quando haja a transmissão imediata de uma coisa por uma parte e a contrapartida do pagamento do preço por outra, bem como quando somente se constitui uma obrigação para uma ou para outra parte, ou o cumprimento de uma prestação ou para ambas.

Entretanto, a natureza genérica da doação é mais forte, pois possui regras comuns à doação em geral e prevalece sobre ela o caráter de causa real.

Isso porque, ressalta o estudioso, a doação obrigatória não existe como contrato autônomo até a época de Justiniano e a consideração do espírito de liberdade que conduz aquele que se priva da coisa faz como que ele, após a entrega da mesma, esteja desonerado da obrigação.

Já na compra e venda, ao contrário, a natureza genérica é dissimulada no direito romano pela estrutura especial da compra e venda obrigatória, a qual tem regras próprias.

Esclarece P. BONFANTE ${ }^{79}$ que a compra e venda obrigatória prevalece sobre a compra e venda real, pois, antigamente, era reconhecida como negócio bilateral (contractus) e, em decorrência disso, raramente não constituía uma obrigação para ambas as partes ou pelo

\footnotetext{
${ }^{76}$ Le singole cit. (nota 10 supra), p. 575.

${ }^{77}$ L. VACCA, La strutura originaria dell'usucapione, in Enciclopedia del diritto, vol. XLV, Milano, Giuffrè, 1992, p. 1003.

${ }^{78}$ Le singole cit. (nota 10 supra), p. 576.

${ }^{79}$ Le singole cit. (nota 10 supra), p. 576.
} 
menos para uma delas.

Ademais, isso sem deixar de considerar que nem mesmo a transmissão da coisa é suficiente para exaurir o vendedor de todas as obrigações.

O autor faz a seguinte distinção entre a compra e venda real e a compra e venda obrigatória:

Na compra e venda real, quando o transmitente for o proprietário, a propriedade da coisa e o respectivo preço pago por ela são passados imediatamente, entretanto, o comprador poderá se ver na condição de ter que usucapir, caso o transmitente não seja o verdadeiro proprietário.

Em relação a esta concepção de compra e venda real, resumir o ato em obrigação e pagamento e considerar todo negócio como um pagamento concomitante ao surgimento da obrigação, é "ben più che una mera sottigliezza, un errore gravíssimo, generato dall'oscurità che regna circa la dottrina della causa. Qui, causa unica, causa immediata e reale è la compra-vendita ${ }^{80 ",}$

Já na compra e venda obrigatória é necessário uma solutio, tanto para a passagem da propriedade como para o usucapião, nesse caso, a causa real e próxima é a própria solutio, enquanto a causa obrigatória e remota é a compra e venda.

Acolhendo tais definições como válidas, em relação à compra e venda obrigatória, a qual acomoda como sua base e sua justificativa a solutio, não seria equivocado nomeá-la de pro soluto.

Isso porque se o contrato obrigatório de compra e venda é causa remota, pareceria, diz P. BonfANTE, "che di esse non si debba discorrere nè punto nè pocco, che debba restar nell'ombra, come qualunque altro contratto obbligatiorio, di fronte alla solutio" ${ }^{\text {" } 1 .}$

Assim, sem gerar qualquer dificuldade de interpretação, este contrato que padeceria na sombra, poderia ser absolutamente putativo e, por consequência, para pesquisar o título verdadeiro seria necessário observar a causa próxima, a solutio.

Conforme assinala o autor, existe uma peculiaridade com a qual se depara na compra e venda, a qual inquieta permanentemente os intérpretes: para que se constitua o título verdadeiro, não basta que a solutio ocorra ex causa emptionis, exige-se também a existência

\footnotetext{
${ }^{80}$ Le singole cit. (nota 10 supra), p. 576-577.

${ }^{81}$ Le singole cit. (nota 10 supra), p. 577.
} 
de uma causa precedente, a emptio-venditio.

\subsection{O título pro emptore a a emptio-venditio}

Por essa razão, também no caso de compra e venda obrigatória o usucapião ocorre pro emptore e não pro soluto, com a diferença daquilo que se verifica nos outros contratos obrigatórios.

De modo mais claro, isso pode ser observado no texto de Paulo, em D. 41, 3, 48:

"Si existimans debere tibi tradam, ita demum usucapio sequitur, si et tu putes debitum esse. Aliud, si putem me ex causa venditi teneri et ideo tradam: hic enim nisi emptio praecedat, pro emptore usucapio locum non habet. Diversitatis causa in illo est, quod in ceteris causis solutionis tempus inspicitur neque interest, cum stipulor, sciam alienum esse nec ne: sufficit enim me putare tuum esse, cum solvis: in emptione autem et contractus tempus inspicitur et quo solvitur: nec potest pro emptore usucapere, qui non emit, nec pro soluto, sicut in ceteris contractibus".
Se eu lhe entrego algo acreditando que lhe devo, somente se procede o usucapião se você também acredita que o débito existe. Diferente seria o caso, se eu me considerasse obrigado em decorrência de uma venda e por isso lhe faço a entrega, pois então, se não acontece $<$ de verdade $>$ uma venda, não tem lugar o usucapião pro emptore. A razão da diferença está em que em outras causas se tem em conta o momento do pagamento e não interessa, quando estipulado, saber se a coisa é alheia ou não, pois basta que eu acredite que aquilo é seu quando me pagas, ao passo que para a compra se considera o momento do contrato e do pagamento e não pode usucapir pro emptore aquele que não comprou, nem sequer pro soluto, como acontece nos demais contratos.

Paulo delimita de maneira cautelosa a diferença do título pro emptore, em relação aos outros contratos obrigatórios.

Segundo P. BONFANTE ${ }^{82}$ é na estrutura especial da emptio-venditio ${ }^{83}$ romana que se

\footnotetext{
${ }^{82}$ Le singole cit. (nota 10 supra), p. 578.

${ }^{83}$ Conforme R. MONIER, emptio-venditio é um contrato consensual, de boa-fé, sinalagmático perfeito, que faz
} 
fundamenta esta exceção, a qual poderia ser facilmente constatada.

Esse contrato consensual (emptio-veditio) estabelece obrigações e acarreta a transferência da posse e a garantia do gozo absoluto sobre a coisa, mas não implica obrigatoriamente na transferência a propriedade.

Por essa razão os romanos a colocam em contraste com a stipulatio.

Ainda mais estreita do que possa parecer, é a correlação que os romanos fazem entre a emptio-venditio e a locatio-conductio, mesclando as regras dos dois institutos.

A respeito dessa correlação, assinala o citado autor, que nem um nem outro instituto impõe, forçosamente, a transferência de um direito, a diferença substancial entre eles é que o primeiro acarreta a privação perpétua, enquanto que o segundo gera tão somente a privação temporária da coisa.

Assim, com a tradição da posse ou com a prestação do habere licere, a consequência será a transição da propriedade.

A jurisprudência romana demonstra querer compreender essa estrutura da emptiovenditio de modo que o faça atingir a finalidade da transmissão do domínio, com exceção em três situações clássicas citadas por P. BONFANTE ${ }^{84}$ :

A primeira, no que tange às regras em que o vendedor age com dolo, tendo conhecimento de que a coisa era alheia e, por consequência, ela não foi considerada transmitida.

Nessa primeira, verifica-se a má-fé e a evidente lesão a outrem, portanto, para fim de usucapião, não seria admitida por título putativo e muito menos por título verdadeiro.

A segunda exceção refere-se ao caso de um terceiro, o qual impede legalmente a aquisição pelo comprador, por exemplo, a situação narrada por Pompônio em D. 19, 1, 3 pr.

Aqui, o negócio é interrompido pela ação de um terceiro estranho à compra e venda.

Representa a terceira exceção, as partes eventualmente ajustarem que não haverá a transição do domínio sobre coisa.

O que se observa nessa hipótese, é que a posse permanece com o vendedor, logo, não

nascer ao vendedor a obrigação de entregar ao adquirente a posse pacífica e durável da coisa vendida (merx) e ao comprador, a responsabilidade de transferir ao alienante o pagamento do preço (pretium) que deve ser necessariamente fixado em moeda cunhada, conforme a opinião dos Sabianianos (Vocabulaire de Droit Romain, $4^{\mathrm{a}}$ ed, Montchrestien, Domat, 1949, p. 110).

${ }^{84}$ Le singole cit. (nota 10 supra), p. 579. 
se inicia a contagem do prazo para o usucapião.

O mais importante, orienta P. BONFANTE ${ }^{85}$, é que para que se possa desvendar o objeto do presente estudo, deve-se considerar que a emptio-venditio em si, e por si, pode ser, mas não é essencialmente direcionada à aquisição da propriedade.

$\mathrm{Na}$ prática, sua função até pode ser esta, mas sua construção, mesmo que seja perfeitamente adaptada ao objeto, não se confunde esse fim, seja qual for a causa desta estrutura anômala.

Todavia, a emptio-venditio, ainda que possa ser, não é essencialmente direcionada à aquisição da propriedade e assim como cada um dos outros contratos precedentes à solutio real, ela é uma obrigação ad dandum.

Esclarece P. BONFANTE ${ }^{86}$, que isso acarreta com que a solutio pura e simples de compra e venda não possua por si mesma o caráter de iusta causa de aquisição real e de usucapião.

$\mathrm{O}$ autor assevera que supondo que seja verdadeira a premissa de que a eficácia real da solutio não é subordinada à existência e à validade do negócio obrigatório, por outro lado, o seu valor e o seu caráter jurídicos são bem determinados pela natureza da obrigação, como no título pro soluto já se adverte.

Logo, considerando que seria um negócio totalmente ineficaz a solutio de uma promessa de doar entre cônjuges, assim como uma promessa de dote entre pessoas que não possam se casar, por consequência, a solutio de compra e venda também não é negócio eficaz perante o objeto do nosso estudo.

Para tanto, sugere o autor em comento, que se deve regressar ao momento da compra e venda para verificar, adequadamente, se existe no caso uma relação que justifique a posse civil e o usucapião.

Não porque se pretenda buscar uma causa remota, mas porque a solutio de compra e venda não é idônea a constituir a causa próxima.

Esta é, para P. BONFANTE ${ }^{87}$, a verdadeira singularidade da compra e venda e a que merece ser colocada em destaque.

\footnotetext{
${ }^{85}$ Le singole cit. (nota 10 supra), p. 579.
} 


\subsection{O momento da boa-fé no título pro emptore}

Existe outra singularidade que tem atraído mais a atenção dos escritores, provavelmente em decorrência do seu caráter mais visível, colocando a primeira singularidade em segundo plano, não obstante o fato de que o citado autor considera aquela mais relevante.

Esta singularidade atinge a essência natural da relação, o seu íntimo, onde a iusta causa tem a sua expressão: ela se refere à boa-fé no título pro emptore.

Assevera P. BONFANTE ${ }^{88}$ que é de conhecimento geral que a boa-fé é exigida no usucapião no momento da tomada da posse, contudo, esta regra parece ser diferente no título pro emptore, bem como há sinais - identificados inclusive pelos antigos - da existência de uma divergência de posições entre os Sabinianos e os Proculeianos.

Em comum, as duas escolas concordavam com a exigência da boa-fé no título pro emptore no momento da conclusão do contrato.

Os Sabinianos exigiam, conforme a regra geral (teoria dos dois tempos), a boa-fé no momento da tradição, já os Proculeianos a renunciavam por completo, operando, portanto, uma mera transição deste requisito da data da tradição até a data do contrato.

Essa controvérsia é observada em D. 41, 3, 10 pr., bem como em D. 41, 3, 44, 4, e a opinião sabiniana é vista em D. 41, 3, 48, em D. 41, 4, 2, em D. 41, 4, 7, 4, e em D. 6, 2, 7, 17.

Deve-se ressaltar, outrossim, que a teoria dos dois tempos foi acolhida pelo direito justinianeu.

Uma dúvida suscitada por P. BonfANTE ${ }^{89}$ refere-se à origem dessa controvérsia e dessa nova singularidade.

O autor sugere que ela é apenas uma consequência da singularidade precedente, pois o objetivo de se recorrer à compra e venda é o de assegurar que a iusta causa, por si mesma, não seja expressa pela solutio da própria compra e venda.

Isso porque, para se ter certeza que uma iusta causa existe, não basta sequer ter certeza da existência de uma compra e venda.

\footnotetext{
${ }^{86}$ Le singole cit. (nota 10 supra), p. 580.

${ }^{87}$ Le singole cit. (nota 10 supra), p. 580

${ }^{88}$ Le singole cit. (nota 10 supra), p. 580.
} 
Esclarece o autor, que deve ser utilizado o mesmo critério para certificar-se que a compra e venda foi realizada corretamente para que, como consequência, possa acarretar ao comprador a verdadeira transferência da propriedade e não a mera tradição e garantia pessoal da posse.

Logo, se a situação não ocorreu com esse rigor, o que se pretende é que se acredite que ela ocorreu dessa forma.

Aduz P. BONFANTE ${ }^{90}$ que a partir disso começa a se vislumbrar a exigência da boa-fé do comprador no momento do contrato, para que então possa-se justificar a delimitação que os romanos desenvolveram e que, em parte, se pretende analisar através do conceito da bona fides no início da posse.

Isso explica a posição de Paulo, quando observou a necessidade de uma real emptiovenditio bonae fidei, como no texto citado por ele em D. 41, 3, 48 e, de forma mais clara, em D. 41, 4, 2 pr.:

"Pro emptore possidet, qui re vera emit, nec sufficit tantum in ea opinione esse eum, ut putet se pro emptore possidere, sed debet etiam subesse causa emptionis. Si tamen existimans me debere tibi ignoranti tradam, usucapies. Quare ergo et si putem me vendidisse et tradam, non capies usu? Scilicet quia in ceteris contractibus sufficit traditionis tempus, sic denique si sciens stipuler rem alienam, usucapiam, si, cum traditur mihi, existimem illius esse: at in emptione et illud tempus inspicitur, quo contrahitur: igitur et bona fide emisse debet et possessionem bona fide adeptus esse".
Possui pro emptore, aquele que compra de verdade, e não basta que ele creia que possui pro emptore, mas deve existir realmente a causa emptionis. Sem embargo, se lhe entrego algo acreditando que lhe devo, ainda que você ignore, poderá usucapir-lo. Por que, pois, se creio que lhe vendi algo e lhe entrego não poderá usucapir-lo? Precisamente, porque nos outros contratos basta o momento da tradição; assim, se cientemente estipulou-se uma coisa alheia, poderá usucapir sempre que, quando entregues a mim, eu acredite que pertença àquele que me a entrega, porém, a compra atende também ao momento do contrato: assim, deve ter comprado de boa-fé, e ter tomado posse, também em boa-fé.

Assevera P. BONFANTE ${ }^{91}$ que a importância do citado fragmento é que, de maneira

\footnotetext{
${ }^{89}$ Le singole cit. (nota 10 supra), p. 581.

${ }^{90}$ Le singole cit. (nota 10 supra), p. 581.

${ }^{91}$ Le singole cit. (nota 10 supra), p. 582.
} 
despercebida, ele é o único texto que trata pura e simplesmente da emptio ou da emptor em matéria de usucapião, pois em todos os demais casos recorre-se à bonae fidei emptio ou bonae fidei emptor nas aquisições a non domino.

Nesse fragmento, a iusta causa de usucapião é ainda mais restrita que o conceito da emptio-venditio em geral.

O autor convida-nos a confrontar o fragmento com o texto de Juliano, D. 41, 3, 33, 3 pr:

"Non solum bonae fidei emptores, sed et omnes, qui possident ex ea causa, quam usucapio sequi solet, partum ancillae furtivae usu suum faciunt, idque ratione iuris introductum arbitror: nam ex qua causa quis ancillam usucaperet, nisi lex duodecim tabularum vel Atinia obstaret, ex ea causa necesse est partum usucapi, si apud eum conceptus et editus eo tempore fuerit, quo furtivam esse matrem eius ignorabat.".

\begin{abstract}
Não somente os compradores de boa-fé, mas todos os que possuem por uma causa a qual geralmente conduz ao usucapião, podem adquirir por usucapião o filho de uma escrava furtada e eu creio que isso é fundado em direito, pois é necessário que se possa usucapir o filho em virtude da mesma causa pela qual se poderia usucapir a escrava, se não for impedido pela Lei das XII Tábuas e pela Lei Atínia, <que proíbem o usucapião de coisas furtadas>; isto, sempre que o filho tenha sido concebido e a escrava veio a dar a luz estando em poder daquele possuidor e sem saber ele que a mãe havia sido furtada.
\end{abstract}

Deve-se ressaltar, ainda, que quando a iusta causa é mencionada na ação Publiciana, refere-se sempre à emptio venditio bonae fidei e tendo sido ela incluída na forma da Publiciana, podia-se também mencionar a boa-fé no caso de compra e venda.

Para P. BONFANTE ${ }^{92}$, isso explica os brocardos tão perseguidos por Ulpiano na D. 6, 2, 7, 11: "Praetor ait: Qui bona fide emit ${ }^{93 ", .}$

E o que o Ulpiano faz a seguir, quase resume as considerações do citado autor: "Non igitur omnis emptio proderit, sede ea quae bonam fidem habuit ${ }^{94 " ; ~ i s t o ~ e ́, ~ i u s t a ~ c a u s a ~ t a n t o ~ d e ~}$ ação Publiciana como de usucapião é a compra e venda de boa-fé.

\footnotetext{
${ }^{92}$ Le singole cit. (nota 10 supra), p. 582.

${ }^{93}$ Disse o pretor: aquele que comprou em boa-fé.

${ }^{94}$ Não serve, pois, toda compra, senão aquela que tem a boa-fé.
} 
$\mathrm{O}$ autor sustenta que esta concepção parece amoldar-se à opinião sustentada por R. STINTZING $^{95}$, a qual já foi também manifestada por V. SCIALOJA ${ }^{96}$ de que a boa-fé no ato da compra e venda deve ocorrer como um complemento obrigatório do título, já que a transferência da propriedade não é consequência obrigatória do negócio.

Entretanto, a preocupação não deve recair apenas em relação à boa-fé, mas também à própria compra e venda, pois, conforme nos esclarece P. BONFANTE ${ }^{97}$, é observando o negócio obrigatório que se justifica a necessidade de um verdadeiro título de usucapião.

Por outro lado, o autor em comento nota que R. STINTZING ${ }^{98}$, por não ter um conceito ajustado da essência do título - uma vez que entre os títulos de usucapião esse autor encaixa ainda a stipulatio -, obriga-o a não acompanhar essa posição.

Ademais, a exemplo dos demais escritores, ele acaba voltando sua atenção à primeira e menos essencial singularidade, que é o momento da boa-fé.

Em relação aos demais casos que guardem eventual semelhança ao caso tem tela, o usucapião não ocorre pro stipulatu ou pro legato, mas sim, pro soluto.

Isso porque a boa-fé, mesmo no caso em exame, não poderia integrar a solutio no momento dela.

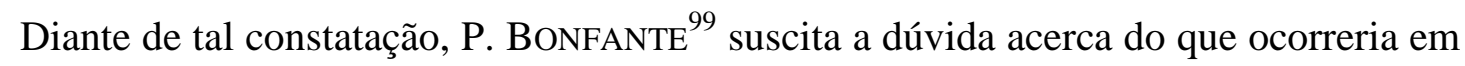
relação à traditio, pois, em outra análise, se o comprador acredita que a coisa comprada pertence ao vendedor, nesse caso a boa-fé deveria ser suficiente ao usucapião diante da ausência de lesão a terceiros, mesmo que sequer tenha havido a stipulatio.

Explica o autor que não há dificuldade para enfrentar essa questão, pois a solutio é causa insuficiente para a compra e venda, haja vista que ela não vincula a transmissão do domínio e é determinada por ela.

Nesse passo, ao se afirmar que é necessário integrar a solutio ou que ela deva ser afastada da condição de iusta causa, ocorre que, mesmo integrando-a, deve-se recorrer aos elementos objetivos que possuam existência e valor jurídico e não aos elementos subjetivos, ainda que possível.

\footnotetext{
${ }^{95}$ Bona fides, pp. 113-117, cit. por P. BONFANTE, Le singole cit. (nota 10 supra), p. 583.

${ }^{96}$ Lezioni, 1888-1889, p. 230, cit. por P. BONFANTE, Le singole cit. (nota 10 supra), p. 583

${ }^{97}$ Le singole cit. (nota 10 supra), p. 584.

${ }^{98}$ Bona fides, pp. 113-117, cit. por P. BONFANTE, Le singole cit. (nota 10 supra), p. 583.

${ }^{99}$ Le singole cit. (nota 10 supra), p. 584.
} 
Todavia, adverte P. BONFANTE ${ }^{100}$ que é necessário voltar-se à analise da compra e venda para identificar se ela foi realizada em boa-fé, pois, se positivo, o título será naturalmente transportado sobre essa compra e venda de boa-fé.

No que tange à explicação de R. STINTZING ${ }^{101}$, a crítica mais severa contra ela pode surgir mesmo antes do próprio autor tê-la rejeitado.

Segundo P. Bonfante ${ }^{102}$, com exceção de C. ApPLEton ${ }^{103}$ os demais escritores partilham de um equívoco comum de não enxergar que um dos lados da questão não é o mais importante.

B. WINDSCHEID ${ }^{104}$, no entender do romanista italiano, corrigiu e expôs, de maneira mais adequada, o pensamento de E. HuSCHKE ${ }^{105}$.

Para B. WindSCHEID, a atenção deve se voltar ao momento do contrato, pois esse é o momento em que a propriedade é passada nas relações entre comprador e vendedor, ademais, ali já se observa um princípio de apropriação no próprio ato da compra e venda.

Essa ideia, na opinião de P. BONFANTE ${ }^{106}$, além de arbitrária é descaradamente antiromana.

Ela traduz uma confusão do intérprete entre a compra e venda real - que não fornece qualquer dificuldade de compreensão - e a emptio-venditio obrigatória, que é justamente aquela sobre a qual se questiona.

Segundo o autor, essa confusão induziu à corrente de ideia moderna que levou a abolir a compra e venda obrigatória nos códigos modernos ou que, pelo menos, excluiu o título dela.

E surge ainda a ideia de que a bona fides é imprescindível no momento da tradição, pois é nesse ato que se deveria cumprir a aquisição da propriedade.

Assevera o estudioso que esse pensamento penetrou ainda mais entre os escritores que a anterior e é em decorrência dele que R. STINTZING abandonou a sua antiga e eficaz interpretação.

A impressão que P. Bonfante tem em relação a esse pensamento de R. Stintzing é

\footnotetext{
${ }^{100}$ Le singole cit. (nota 10 supra), p. 584.

${ }^{101}$ Bona fides, pp. 113-117, cit. por P. BONFANTE, Le singole cit. (nota 10 supra), p. 583.

${ }^{102}$ Le singole cit. (nota 10 supra), p. 585.

${ }^{103}$ Publicienne, I, p. 179-1894, cit. por P. BONFANTE, Le singole cit. (nota 10 supra), p. 585.

${ }^{104}$ Pand., 1, $\S 177$, p. 610, cit. por P. BONFANTE, Le singole cit. (nota 10 supra), p. 585.

${ }^{105}$ Das R. publ. Klage, cit. por P. BONFANTE, Le singole cit. (nota 10 supra), p. 585.

${ }^{106}$ Le singole cit. (nota 10 supra), p. 585.
} 
que este considerava que os romanos, diferentemente dos modernos, tinham presente a eficácia real da compra e venda e que, desse modo, esse negócio distinguia-se do verdadeiro negócio obrigatório, do qual o autor toma como referência a estipulação.

Entretanto, para o romanista italiano, além de mal escolhida, essa comparação é feita com a intenção de confundir as ideias, pois a compra e venda é causa e, aliás, causa genérica, logo, pode ser tanto causa real quanto obrigatória.

Por outro lado, a stipulatio é forma e tão somente forma dos contratos obrigatórios.

Nesse sentido, conclui o autor que não há dúvida alguma que, quando a compra e venda for causa real, ela será apta a passagem do domínio e, por consequência, o usucapião acontecerá obviamente pro emptore.

Ademais, é com base nessa compra e venda real que acontece, frequentemente, a transição de propriedade no comércio cotidiano.

Por outro lado, continua P. BONFANTE ${ }^{107}$, se a compra e venda for contrato obrigatório, este, relativamente à aquisição de direito real, deveria atuar como causa remota, seja quando concluída e reconhecida independentemente da forma, seja quando for reduzida à forma de uma stipulatio.

Isso não se refere somente ao usucapião.

Pode também ser possível não existir no testamento, na estipulação, no mútuo ou em qualquer outro negócio em que a solutio seja necessária, ou seja, um negócio que pode nem ser o mesmo da emptio-venditio.

Ainda que isto seja esclarecido, não ajuda no escopo de reduzir o negócio obrigatório à função real.

Para o autor, não há argumento para esta confusão doutrinária, especialmente quando a compra e venda, em sua estrutura, oferece uma anomalia que quando colocada em correlação à essência do título, deve conduzir ao resultado que alcançaram os romanos, obrigatoriamente.

Observa o estudioso que em virtude de um mero acidente histórico outros escritores teriam sustentado, com veemência, a posição desesperada de buscar sempre explicação para este problema.

Alguns escritores teriam defendido que o Edito Publiciano concedia ação homônima $e i$

${ }^{107}$ Le singole cit. (nota 10 supra), p. 586. 
qui bona fide emit.

Para P. BonfAnTE ${ }^{108}$, ao se depreende do contexto de todos os fragmentos de Ulpiano inseridos no título da Publiciana, a palavras do jurisconsulto pertencem à fórmula e não ao Edito.

Outros, dizem que no período do ius gentium a compra obrigatória teve lugar na compra e venda real e ela manteve o nome de compra e venda.

Para o usucapião continuava-se exigindo a boa-fé no momento do contrato, mas isso não persistiu, uma vez que, posteriormente, não era mais nesse momento que se dava a aquisição da propriedade.

Enfrentando as duas teorias, P. BONFANTE ${ }^{109}$ tece críticas veementes em relação a ambas.

A primeira teoria o autor considera como arbitrária, pois o que ela é faz é apenas deslocar uma das duas questões, pois, também em relação à Publiciana, ocorrerá o problema da boa-fé no ato da compra e venda.

Por conseguinte, afirma que consiste em "spiegazione torbida la seconda110", porquanto, dá a impressão de que parte do pressuposto equivocado de que a boa-fé, em geral, i.e, em qualquer título de usucapião, esteja relacionada com o contrato, quando na verdade ela está relacionada à tomada da posse.

Assevera, então, que a explicação mais adequada seria a de C. APPLETON ${ }^{111}$, a qual se aproxima mais do seu pensamento.

Ele a explica através do seguinte exemplo: conforme diz Paulo, se existe uma compra e venda, não se usucape pro soluto, mas pro emptore, logo, se exige que haja uma compra e venda efetiva e, simultâneamente, realizada em boa-fé, porque esta deve ser concomitante ao título.

Subsiste então, a necessidade de explicar porque não se pode ocorrer pro soluto o usucapião.

O autor salienta que a resposta está no fato de que, a princípio, a compra e venda não era um verdadeiro contrato civil, assim, não acarretava uma verdadeira solutio.

\footnotetext{
${ }^{108}$ Le singole cit. (nota 10 supra), p. 587.

${ }^{109}$ Le singole cit. (nota 10 supra), p. 588.

${ }^{110}$ Le singole cit. (nota 10 supra), p. 588.

${ }^{111}$ Publicienne, I, p. 198, cit. por P. BONFANTE, Le singole cit. (nota 10 supra), p. 588.
} 
Mas, conforme C. ApPLETON, na época de Paulo, o direito civil reconhecia bem a compra e venda, entretanto, foi com base na força da mera tradição histórica que o princípio perdurou.

Deve-se considerar, segundo P. Bonfante ${ }^{12}$, o pensamento de G. PuChTA ${ }^{113}$. Para este autor, a boa-fé deve acompanhar o título, especialmente quando este for um ato jurídico separado da aquisição da posse.

Para P. BONFANTE ${ }^{114}$, essa explicação parece ter um fundo de razoabilidade, todavia, não responde porque ela se refere a este título na compra e venda de forma separada na tomada da posse e porque não se refere à solutio.

Sugere o autor, que para se buscar a resposta a esta indagação, deve-se examinar um texto obscuro de Ulpiano (D. 41, 3, 10 pr.), entretanto, frequentemente citado em apoio às opiniões mais divergentes:

"Si aliena res bona fide empta sit, quaeritur, ut usucapio currat, utrum emptionis initium ut bonam fidem habeat exigimus, an traditionis? Et obtinuit Sabini et Cassii sententi traditionis initium spectandum."

\begin{abstract}
Se uma coisa alheia é comprada de boa-fé, e começa a correr <o tempo do> usucapião, exigimos para a boa-fé, como primeiro momento, o da compra e o da tradição? Prevaleceu a opinião de Sabino e de Cássio de que deve ser considerar o primeiro momento o da tradição.
\end{abstract}

Da análise desse texto, P. BonfAnte ${ }^{115}$ conclui que aparentemente havia uma controvérsia entre os jurisconsultos romanos sobre o decurso do usucapião, se a exigibilidade da boa-fé se daria no momento da venda ou de tradição.

Parece ter prevalecido a ideia que somente no momento da tradição é que ela deve ser observada.

Sustenta o citado romanista que o problema é que, se o fragmento de Ulpiano for compreendido dessa forma, certamente não será bem conciliado com o texto em que Paulo, de maneira contundente, se expressa no sentido de que na compra e venda a boa-fé é necessária em ambos os momentos.

\footnotetext{
${ }^{112}$ Le singole cit. (nota 10 supra), p. 589.

${ }^{113}$ Inst., edição Rudorff, Leipzig, 1851, II, p. 664, cit. por P. BONFANTE, Le singole cit. (nota 10 supra), p. 589.

${ }^{114}$ Le singole cit. (nota 10 supra), p. 589.

${ }^{115}$ Le singole cit. (nota 10 supra), p. 589.
} 
Consequentemente, considerando que ninguém além do próprio Ulpiano manifestou tal opinião de maneira tão engenhosa em outro fragmento, como em D. 6, 2, 7, 17, pode-se afirmar que Ulpiano entra em aberta contradição consigo mesmo.

Salienta o autor que, como de costume, tratando-se de usucapião, começa-se a discorrer naturalmente não sobre emptio, mas sobre bonae fidei emptio: "si aliena res bona fide empta” sit, logo, a contradição é identificada no mesmo fragmento em questão.

Buscou-se compreender este trecho como se o jurisconsulto dissesse "an etiam traditionis”, porém, segundo P. BONFANTE ${ }^{116}$, esta parece ser uma interpretação forçada, tal como consta no texto nas Pandectas.

Diz o autor, que a suposição de E. HuSCHKE ${ }^{117}$ é no sentido de que Ulpiano não põe em discussão qual o momento em que a boa-fé deve estar presente, mas sim, a partir de qual momento o usucapião ocorre.

Por isso, o inciso "ut bonam fidem habeat" deveria ser compreendido como um parênteses "posito ut bonam fidem habeat".

Para P. Bonfante, outra observação que deve ser considerada é a de C. ApPleton, uma vez que a de E. HUSCHKE parece também equivocada.

Observa o romanista italiano que, segundo afirma C. APPLETON ${ }^{118}$, Ulpiano veio a se repetir "in un modo troppo ridicolo ${ }^{119}$ ", já que começou dizendo que a coisa foi comprada em boa-fé, além do mais, deveria ter sido dito: "spectamus" ao invés de "exigimus".

C. ApPleton deduz, ainda, que os copistas ou os compiladores do Digesto teriam mudado mptionis (isto é, mancipationis) para emptionis.

Assim, se a discussão de Ulpiano devia ser direcionada sobre uma res mancipi, logo, a boa-fé deveria ser exigida no meio da traditio ou da mancipatio, mas essa seria uma conjectura difícil de comprovar ${ }^{120}$.

P. BONFANTE esclarece que não se demonstra razoável que um debate desse jaez possa ter se proliferado entre os jurisconsultos clássicos, pois, na tradição, a boa-fé é exigida como princípio da posse, logo, na mancipatio, caso esta ocorra desacompanhada da tradição, não produzirá qualquer significado para a posse e nem para o usucapião.

\footnotetext{
${ }^{116}$ Le singole cit. (nota 10 supra), p. 589.

${ }^{117}$ Das R. publ. Klage, p. 63-64, cit. por P. BONFANTE, Le singole cit. (nota 10 supra), p. 585.

${ }^{118}$ Publicienne, I, p. 181-182, nt. 27, cit. por P. BONFANTE, Le singole cit. (nota 10 supra), p. 590.

${ }^{119}$ Le singole cit. (nota 10 supra), p. 590.
} 
Em sua análise, o trecho em comento traz uma interpretação plausível, desde que seja considerado o argumento de Ulpiano de forma contextualizada com o âmbito de aplicação do fragmento, e também se colocado em comparação com aquilo que antecede e aquilo que sucede o referido trecho.

O trecho do fragmento de Ulpiano diz respeito à Publiciana, em especial, à bonae fidei emptio e à tradição em boa-fé.

P. BonfAnTE ${ }^{121}$ informa que o fragmento é extraído do livro XVI do Comentário ao Edito e todo ele é dedicado à Publiciana.

O. LENEL restituiu o texto entre os fragmentos D. 6, 2, 16 e D. 6, 2, 17.

No parágrafo 16, Ulpiano discorreu sobre a compra em boa-fé, tratando, por proêmio, do célebre inciso da fórmula pretória e, em seguida, passou a discorrer sobre o requisito da traditio.

A constatação que faz P. BONFANTE, é que foi suprimido pelos compiladores o inciso da fórmula "et is ei traditus est", resumido também aquilo que o antecede:

"Ut igitur publiciana competat, haec debent concurrere, ut et bona fide quis emerit et ei res empta eo nomine sit tradita: ceterum ante traditionem, quamvis bonae fidei quis emptor sit, experiri publiciana non poterit”.

\begin{abstract}
Assim, para que se proceda a ação Publiciana, deve concorrer que alguém tenha comprado de boa-fé e que lhe tenha sido feita tradição da coisa comprada por esta causa; caso contrário, antes da tradição, mesmo que alguém seja comprador de boa-fé, não pode exercitar a ação Publiciana.
\end{abstract}

No parágrafo 17, solicitando a autoridade de Juliano (Iulianus scripsit), Ulpiano afirma que a tradição da coisa comprada deve proceder-se em boa-fé, uma vez que, estando ciente de que a coisa comprada é uma res aliena, não se poderá admitir a Publiciana "quia usucapere non poterit".

Em todo o andamento do texto, o jurisconsulto romano reafirma, de modo conclusivo, que também a compra e venda deve ocorrer sempre em boa-fé.

Consoante aguda observação de P. BONFANTE, "la controversia ricordata nel frammento in questione è ben diversa da ciò che, a prima vista, nonostante la repugnanza

\footnotetext{
${ }^{120}$ C. Appleton, Publicienne, I, p. 200-203, nt. 27, cit. por P. BONFANTE, Le singole cit. (nota 10 supra), p. 590.
} 
colle parole iniziale (Si aliena "res bona fide empta sit"), poteva parere ${ }^{122, "}$

Contudo, menciona constantemente o citado autor que o objeto da discussão não se refere ao momento em que boa-fé deverá ocorrer, o fato é que, sem nenhuma dúvida, a compra e venda deve ser realizada em boa-fé.

Para a Publiciana exige-se a bonae fidei emptio na tradição, todavia, a fórmula da Publiciana não diz nada acerca da bona fides no ato da traditio, especialmente, onde Ulpiano narra o fundamento da ação justificando a possibilidade da usucapio.

Se uma res aliena foi comprada de boa-fé e a propriedade vem a ser adquirida pelo decurso do usucapião, o momento que deve ser observado é o da compra e venda, pois, para este título, a boa-fé é exigida no ato em que é colocado em existência.

Entretanto, nem por isso ela seria dispensada no momento da posse.

Esclarece P. BONFANTE ${ }^{123}$ que a primeira boa-fé é exigida para integrar o título, pois, do contrário, este não será admitido como título de posse civil ou de propriedade.

Contudo, não é menos verdade que uma vez provada a bona fides no ato da compra e venda, visto que, enquanto não se tinha a bona fides, tinha-se menos que nas outras iustae causae, neste ato, passa a ter mais.

Antes, tinha-se menos porque a emptio-venditio, por si, não acarreta obrigatoriamente a transferência da propriedade, entretanto, agora tem-se mais porque a emptio venditio bonae fidei significa não somente a convicção de que esta obrigação existe, mas também a convicção de que o alienante é o verdadeiro proprietário.

O autor salienta que diante de tais observações, emergiu a dúvida se esta convicção não poderia fazer as vezes da boa-fé, que por seu turno, deve também existir no início da posse.

Por consequência, ele nos adverte que foram reflexões como esta que acabaram induzindo os jurisconsultos da escola proculeiana a dispensar a boa-fé no princípio da tradição no caso de emptio-venditio bonae fidei.

Deduz o citado romanista, ainda, que distorções provocadas na estrutura da ordem natural e social são feitas de forma que uma acaba sendo consequência da outra, nesse caso, induz o raciocínio a um resultado posterior onde a solutio deve fazer referência ao contrato

${ }^{121}$ Le singole cit. (nota 10 supra), p. 590.

${ }^{122}$ Le singole cit. (nota 10 supra), p. 591. 
obrigatório e exigir que este seja de boa-fé, todavia, esta linha de pensamento não obteve sucesso.

Segundo P. BonfAnte ${ }^{124}$ a doutrina que prevaleceu foi aquela formulada pelos principais pensadores da escola sabiniana, a qual acabaria consolidando o princípio de que era preciso exigir a boa-fé no momento da tradição, mesmo na hipótese de emptio-venditio bonae fidei.

Semelhantemente pensava Juliano, no sentido de que o comprador não poderia valerse da Publiciana quando, cientemente, tivesse recebido a tradição de uma res aliena, até mesmo porque, nesse caso, o usucapião não seria admitido.

Não obstante, afirma o autor que Ulpiano nos previne de maneira diligente contra uma falsa interpretação do caso em exame.

O jurisconsulto adverte que não se deve fazer referência à boa-fé no momento da compra e venda.

Esta observação, inserida no fragmento D. 6, 2, 7, 17, cuja tradução será realizada logo adiante, acabou se tornando muito comentada pelo jurisconsultos ${ }^{125}$.

A exemplo de P. BONFAnTE, mais recentemente a autora L. VACCA ${ }^{126}$ também analisou conjuntamente os fragmento D. 41, 3, 48 e D. 41, 4, 2 pr.

Para a mencionada romanista, Paulo afirma que a causa empti se distingue de outras modalidades de aquisição feitas por intermédio de traditio ex iusta causa, pois em relação ao adquirente de boa-fé, esta deve estar presente também no momento da compra e venda e não somente no ato da traditio.

Logo, tem-se, na hipótese, um entendimento diferente do requisito da boa-fé em relação às causa empti e às traditionis que se amoldem a outras causas contratuais.

Arremata a autora, sustentando que somente se verificaria a causa emptionis onde ou quando houvesse a boa-fé no ato da conclusão do contrato.

A boa-fé não poderia ser considerada nos casos em que o comprador, no momento da compra e venda, tivesse a ciência que a coisa não era de propriedade do vendedor, ainda que no momento da traditio estivesse convencido de que o transmitente era o proprietário.

\footnotetext{
${ }^{123}$ Le singole cit. (nota 10 supra), p. 591.

${ }^{124}$ Le singole cit. (nota 10 supra), p. 592.

${ }^{125} \mathrm{O}$ mesmo entendimento se observa em Pand., I, § 320, nota 2, n. 1, in fine.

126 “Iusta causa" e "bona fides" cit. (nt. 12 supra), p. 1.967-1968.
} 
Pode-se concluir, através do pensamento da autora, que em ambos os momentos (contrato e tradição) a boa-fé era exigida.

\subsection{O pagamento do preço como condição essencial para o usucapião}

Como é sabido, para a aquisição da propriedade o pagamento do preço é condição essencial para a aquisição, isso, evidentemente, quando esta aquisição ocorre por tradição.

Diante de tal constatação, P. BONFANTE ${ }^{127}$ indaga se o pagamento do preço seria também essencial para o usucapião.

O autor observa a existência de divergências na doutrina.

A maior parte dos escritores e também aqueles que para o referido romanista são os mais respeitáveis, afirma que o pagamento do preço é essencial para o usucapião.

Fazem parte desta corrente A. VANGEROW ${ }^{128}$ e B. WINDSCHEID ${ }^{129}$.

Sustentam a opinião contrária C. APPLETON ${ }^{130}$ e R. STINTZING ${ }^{131}$.

Além dos autores citados, uma terceira via defendida por H. FitTing ${ }^{132}$ procura atribuir uma solução para cada período.

Para H. FitTing, no direito clássico, o pagamento do preço devia ser exigido para o usucapião, já no direito justinianeu, considerando que o decurso do prazo para o usucapião teria se alongado, esta exigência não mais subsistiria e, por tal razão, Triboniano teria apagado todos os resquícios deste requisito naquilo que se refere ao usucapião.

Certamente, a teoria comum guarda analogia com a tradição.

Entretanto, P. BONFANTE ${ }^{133}$ põe em dúvida a validade desta analogia, opinando que ela não é correta.

Justifica o seu entendimento, dizendo que não há dúvida de que a iusta causa do usucapião é a mesma iusta causa da tradição, ou melhor, da aquisição do domínio em geral,

\footnotetext{
${ }^{127}$ Le singole cit. (nota 10 supra), p. 593.

${ }^{128}$ Pand., I, § 320, nota 2, n. 1, in fine, cit. por P. BonfanTe, Le singole cit. (nota 10 supra), p. 593.

${ }^{129}$ Pand., I, § 179, n.1; cit. por P. BONFANTE, Le singole cit. (nota 10 supra), p. 593.

${ }^{130}$ Publicienne, I, pp. 216 e ss, cit. por P. BONFANTE, Le singole cit. (nota 10 supra), p. 593.

${ }^{131}$ Das Wesen der b. f. pp. 110-112, cit. por P. BONFANTE, Le singole cit. (nota 10 supra), p. 593.

${ }^{132}$ Arch. für civ. Praxis, vol. LI, pp. 18 e ss. cit. por P. BONFANTE, Le singole cit. (nota 10 supra), p. 593.

${ }^{133}$ Le singole cit. (nota 10 supra), p. 593.
} 
porém, na própria tradição, o pagamento do preço é um elemento necessário à aquisição definitiva e não o elemento da iusta causa.

Esclarece sua posição o autor, afirmando que o requisito da iusta causa é colocado em menor conexão com a emptio-venditio e em maior proporção com a traditio.

Ademais, se refere a uma prescrição positiva das doze tábuas no que tange ao momento da aquisição definitiva, seja esta prescrição conforme as regras do ius gentium ou do ius naturale.

O estudioso extrai sua conclusão da forma pela qual se expressa o próprio Justiniano.

Outro argumento a favor da tese afirmativa - em relação à opinião dominante que se refere sempre à tradição -, é o de que o possuidor não está em boa-fé quando tem ciência de que não poderá adquirir o domínio.

Para P. BONFANTE ${ }^{134}$ essa alegação decorre da costumeira má interpretação da iusta causa e da bona fides, uma vez que nem aquela significa aquisição e nem esta a convicção de ser o proprietário.

Uma justificativa favorável à tese negativa, analisado sob o ponto de vista exegético, é que as fontes silenciam acerca do assunto.

Assinala o autor que H. FitTing ${ }^{135}$, visivelmente inclinado à opinião dominante (tese afirmativa), desenvolve seu pensamento combinando todos os textos que por ventura refiramse ao assunto e, esta tarefa, trouxe algum indício que respalda a tese afirmativa.

Outro caso que é citado como exemplo é o de um comprador que realiza a aquisição de algo de uma mulher sem a auctoritas do tutor ou com a auctoritas de um falso tutor (Frag. Vat. 1).

Detecta P. BONFANTE ${ }^{136}$ que o jurisconsulto Juliano viveu em um tempo em que a tutela da mulher era enfraquecida.

Com base em uma constitutio Rutiliana Juliano teria decidido que aquele que pagou o preço poderia também usucapir; entretanto, nesse caso, o jurisconsulto teria feito referência a uma iusta causa diferente, a qual é exigida especialmente para este caso.

Por outra linha, um texto normalmente apontado como suporte à tese contrária é o

${ }^{134}$ Le singole cit. (nota 10 supra), p. 594

${ }^{135}$ Arch. für civ. Praxis, vol. LI, pp. 18 e ss, cit. por P. BonfanTe, Le singole cit. (nota 10 supra), p. 594.

${ }^{136}$ Le singole cit. (nota 10 supra), p. 594. 
fragmento D. 6, 2, 8, de Gaio:

"De pretio vero soluto nihil exprimitur: unde potest coniectura capi, quasi nec sententia praetoris ea sit, ut requiratur, an solutum sit pretium".
Do preço, não se disse nada a respeito de tê-lo pago, pelo que se pode conjecturar que não está na intenção do pretor que se requeira o pagamento do preço.

De acordo com P. Bonfante ${ }^{137}$, segundo o entendimento do jurista de C. APPLETON $^{138}$, a Publiciana se basearia toda no usucapião e a hipótese conjecturada por Gaio em relação a ela teria sido bem fundada.

Todavia, conclui o citado romanista italiano que se não era exigido o pagamento do preço para o usucapião seria bastante original, para não dizer pior, se existisse um requisito essencial à iusta causa e ao usucapião.

Por isso, as próprias palavras de Gaio pareceriam fazer alusão, ainda que o indício seja um tanto escasso, a um princípio idêntico admitido pelo usucapião.

P. BONFANTE ${ }^{139}$, com o escopo de apresentar as respostas às questões envolvendo o título pro emptore, esclarece, inicialmente, o motivo pelo qual não se pode usucapir pro soluto quando se trata de compra e venda.

Para o autor, esta particularidade quando relacionada à compra e venda mostra-se presente apenas perante o desenvolvimento incompleto do sistema contratual romano.

Na realidade, a solutio é considerada iusta causa usucapionis exclusivamente quando é solutio de um contrato formal ou um negócio tipicamente obrigatório, a exemplo da stipulatio.

Quando se está diante de negócios como a permutatio, a divisio, a transactio, a noxae dedictio, a causa solvendi, o título pro soluto não aparece e nem poderia aparecer.

Em comparação com a compra e venda, a função obrigatória dessas causas justificadoras da transmissão do domínio (iustae causae acquirendi) é desconhecida no direito clássico.

Através dos últimos estudos que P. BONFANTE ${ }^{140}$ teve acesso, o autor observou que se

\footnotetext{
${ }^{137}$ Le singole cit. (nota 10 supra), p. 595.

${ }^{138}$ Publicienne, I, pp. 216 e ss, cit. por P. BONFANTE, Le singole cit. (nota 10 supra), p. 595.

${ }^{139}$ Le singole cit. (nota 10 supra), p. 595.

${ }^{140}$ Le singole cit. (nota 10 supra), p. 595.
} 
chegou à ideia de que a permuta não é contrato e obrigatório e, portanto, a parte que recebeu antes aquilo que foi dado em permuta não estaria obrigada a cumprir com aquilo que prometeu.

Tal raciocínio é justificado pelo fato de que, nesse caso, não se trata do cumprimento da solutio, mas do adimplemento da promessa.

Contudo, acrescenta o mencionado romanista, o título pro soluto (e também a solutio) com base na promessa de doação ou na promessa dotal, representa substancialmente uma ilusão, pois tanto a promessa de doar, como também aquela de dar o dote, devem estar revestidas da forma da stipulatio ou da dictio.

Havia a solutio de uma stipulatio, mas não poderia existir a solutio de uma doação.

Conforme teria declaro Paulo, em D. 41, 3, 48, se os ceteri contractus não se referem ao contractus, mas observam a solutio, são somente contratos formais ou tipicamente obrigatórios, a exemplo do mútuo.

Ademais, ele é praticamente irrelevante para o usucapião, pois tem por objeto coisas fungíveis.

Analisa o autor que a emptio-venditio deve se reaproximar da permutatio, da transactio, etc., e a singularidade do título pro emptore pode ser acentuada pela estrutura particular da compra e venda obrigatória.

Porém, provavelmente o seu fundamento lógico está em um fenômeno de ordem geral que demonstra com mais clareza a essência da iusta causa: a iusta causa adcquirendi, i.e, a iusta causa possidendi, a iusta causa usucapionis, nunca pode ser constituída por um negócio que se apresenta simplesmente como negócio obrigatório.

Se na compra e venda parece que se quer fazer referência a um negócio obrigatório, adverte P. BONFANTE ${ }^{141}$ que isto acontece porque a compra e venda não é exclusivamente fonte de obrigações.

Ascrescenta, ainda, que nas relações obrigatórias que exigem um dare (relações formais, pelo direito clássico) os jurisconsultos levam em consideração o momento que se atua a renúncia mediante a traditio e, estando presente esta vontade de renunciar, conclui-se que não há lesão alheia na apropriação por parte do possuidor, portanto, este momento pareceria suficiente.

${ }^{141}$ Le singole cit. (nota 10 supra), p. 596. 
Entretanto, esta possessio nos textos mais antigos aparece designada com o termo pro suo, destarte, diz o autor, somente Paulo parece ter visto na solutio um título concreto e denominado nos negócios que não são tipicamente obrigatórios.

Em relação esses negócios, os quais P. BONFANTE ${ }^{142}$ denomina-os como "causas genéricas", pode-se sempre considerar a relação independentemente do seu valor obrigatório, ou seja, na sua eficácia real.

Ademais, a traditio da coisa é a conclusão do negócio, não a sua dissolução.

Assim, confirma o autor, se para a justificação real existiu uma promessa anterior à compra venda, pode-se tentar apoiá-la na solutio, porque esta promessa é contrato obrigatório, exceto se o contrato não for revestido da formalidade necessária.

Nesse caso, a compra e venda permanecerá sempre uma causa genérica, pois mesmo se a execução for simultânea à solutio de uma obrigação, o seu significado real poderá ser destruído, exceto se esta solutio nunca se tornou uma datio.

Em resumo, explica P. BONFANTE ${ }^{143}$ que esta anomalia é mais do que aparente.

Se os jurisconsultos clássicos tivessem admitido os contratos obrigatórios de doação, de permuta, de transação e semelhantes (como reconheceram a emptio-venditio consensual) teria-se observado o fenômeno ocorrer nos mesmos termos em uma série de causas.

Diante de tais observações, o citado autor sustenta que elas possuem relevância não só para a usucapio, mas também para a traditio e a condictio.

Quanto à compra e venda enquanto iusta causa, na sua eficácia real, ela constitui uma unidade contínua, a qual vai do momento da conclusão do negócio (initium venditionis) até a sua dissolução (initium traditionis) se houve contrato obrigatório e passa a situar o problema sob o aspecto do momento da boa-fé.

Mas, como se verá adiante, sobre esse mesmo ponto, a exegese crítica integra o resultado naturalístico.

\footnotetext{
${ }^{142}$ Le singole cit. (nota 10 supra), p. 597.

${ }^{143}$ Le singole cit. (nota 10 supra), p. 597.
} 


\subsection{Considerações acerca do debate entre Proculeianos e Sabinianos sobre o} momento da boa-fé

Para P. BONFANTE ${ }^{144}$ não existe a certeza de que os Sabinianos exigissem no título pro emptore a boa-fé nos dois tempos, i.e, no momento do contrato e no momento da tradição.

Esta é uma espécie de teoria eclética acolhida ou até mesmo criada pelos compiladores.

O autor observa que, na realidade, os Sabinianos observavam só o initium traditionis, os Proculeianos o initium contractus, todavia, ambos colocavam a boa-fé em um só momento, o qual variava conforme a hipótese e dado o caráter contínuo da causa.

Afirma o estudioso que este é o sentido do já examinado fragmento D. 41, 3, 10 pr.

Isso porque quando o texto é interpretado livre de ideais preconcebidas, com o escopo de colocar a teoria sabiniana em harmonia com a teoria justinianeia dos dois tempos, subtende-se nesse fragmento um etiam que não existe no texto original e que ficaria mal nele, porque a oposição entre os dois conceitos é falha.

Por intermédio da interpretação do D. 41, 3, 44, 2 de Papiniano, que também acolhe a teoria Sabiniana, extrai-se o mesmo sentido: etsi possessionis, non contractus initium, quod ad usucapionem pertinet, inspici placet, etc ${ }^{145, "}$.

Esclarece P. BONFANTE ${ }^{146}$ que também nesse caso, desde que foram realizadas as glosas para reduzir o texto, a teoria sabiniana dos dois tempos quer que se subentenda tantum (GL. ad. h.l.: hic subaudi tantum, quasi dicat non tantum contractus tempore, sed etiam possessionis).

Ademais, em sentido semelhante, segue a teoria da mesma escola Juliano, em D. 41, 4. 7, 4:

"Qui bona fide alienum fundum emit et possessionem eius amisit, deinde eo tempore adprehendisset, quo scit rem alienam esse,
Aquele que de boa-fé comprou um imóvel alheio e perdeu a posse do mesmo, se logo o tivesse recuperado, quando já sabia que era

\footnotetext{
${ }^{144}$ Le singole cit. (nota 10 supra), p. 597.

${ }^{145}$ Embora seja dito para efeitos de usucapião que se deve atender ao momento da posse e não do contrato , ocorre que, às vezes ...

${ }^{146}$ Le singole cit. (nota 10 supra), p. 598-599.
} 
non capiet longo tempore, quia initium secundae possessionis vitio non carebit, nec similis est ei, qui emptionis quidem tempore putat fundum vendentis esse, sed cum traditur, scit alienum esse: cum enim semel amissa fuerit possessio, initium rursus reciperatae possessionis spectari oportet. quare si eo tempore redhibeatur homo, quo emptor scit alienum esse, usucapio non contingit, quamvis antequam venderet, in ea causa fuerit, ut usucaperet. Idem iuris est in eo, qui de fundo deiectus possessionem per interdictum reciperavit sciens iam alienum esse". alheio, não poderá adquirir pela $<$ posse $>$ de longo tempo, porque o início da segunda posse não será sem vício; < pode se comparar > àquele que, ao comprar o imóvel, acredita que este pertence ao vendedor e vem a saber que é alheio quando lhe é feita a tradição, pois, desde que um perdeu a posse, deve atender-se ao início do posse recuperada; portanto, se devolve um escravo quando o < vendedor que volta a > comprá-lo sabe que o escravo é alheio, não se dá o usucapião por mais que antes da venda estivesse em condições de poder usucapir-lo; o mesmo vale para aquele que foi expulso de um imóvel que recuperou a posse já sabendo que o imóvel era alheio.

Parece ser contraditório às citadas leis o fragmento de Ulpiano, onde o jurisconsulto faz referência ao entendimento de Juliano, em D. 6, 2, 7, 17:

\begin{abstract}
"Iulianus libro septimo digestorum scripsit traditionem rei emptae oportere bona fide fieri: ideoque si sciens alienam possessionem adprehendit, publiciana eum experiri non posse, quia usucapere non poterit. Nec quisquam putet hoc nos existimare sufficere initio traditionis ignorasse rem alienam, uti quis possit publiciana experiri, sed oportere et tunc bona fide emptorem esse".
\end{abstract}

Juliano, no livro sétimo digestorum, escreveu que deve ser feita de boa-fé a tradição da coisa comprada; que, portanto, se a posse é tomada sabendo de que é alheia, não se pode exercitar a ação Publiciana, já que tampouco se poderá usucapir. E não se pense que a nosso juízo basta para poder exercitar a Publiciana que se tenha ignorado que a coisa era alheia ao iniciar o ato de entrega, mas que o comprador deve estar de boa-fé já no momento da compra.

Entretanto, P. BONFANTE, referindo-se ao pensamento de I. ALIBRANDI sustenta que esta solução é mais digna de Triboniano que de Ulpiano ${ }^{147}$.

\footnotetext{
${ }^{147}$ I. AliBRANDI, Possesso, p. 120, cit por P. BonfANTE, Le singole cit. (nota 10 supra), p. 599.
} 
A interpolação foi também citada por M. PAMPALONI ${ }^{148}$, em razão do "nos maiestaticum”, e mais recentemente, por G. BESELER ${ }^{149}$, em decorrência da típica frase compilatória "nec quisquam putet, etc", e que, posteriormente, conforme P. BONFANTE, foi adicionado de maneira incompreensível, a partícula "et tunc”.

Sobre os textos de Paulo, G. BESELER sustenta que ambos são interpolados, o que faz deste jurisconsulto um seguidor da teoria justinianeia dos dois tempos.

Todavia, sugere P. BONFANTE ${ }^{150}$ que Paulo seguia, provavelmente, a teoria proculiana do initium contractus.

O citado autor italiano obseva que no fragmento D. 41, 3, 48 G. BESELER alega que deveria estar escrito: "in emptione contractus tempus inspicitur; e no D. 41, 4, 2 pr., deveria constar: "in emptione illud tempus inspicitur quo contrahitur” suprimindo a frase final, a qual não diz respeito ao mesmo objeto.

Todavia, o autor não acolhe o entendimento de que a interpolação recaia sobre a bona fides no fragmento D. 41, 3, 10 pr, onde se lê "si aliena res bona fide empta sit", a exemplo daquilo que é defendido por I. ALIBRANDI quanto à bona fide em D. 6, 2, 7, 11, i.e, no inciso edital "qui bona fide emit" e todas as sucessivas alusões, que devolvem a esta última lei a bona fides no momento da compra, como defende G. BESELER.

Para P. BONFANTE ${ }^{151}$, os jurisconsultos clássicos parecem ter considerado esta iusta causa como uma relação continuativa que possui um certo "tractus temporis", onde a boa-fé pode ter lugar tanto no momento da conclusão (initium venditionis), como no momento da execução (initium traditionis).

Todavia, seja qual for o momento, caracteriza-se sempre a compra e venda, tornandoa uma bonae fidei emptio.

\subsection{Consideração sobre o pagamento do preço na usucapio pro emptore}

O citado autor afirma que a regra, a qual determina que a compra e venda e o respectivo pagamento do preço consiste, por si, em condição essencial para a passagem da

\footnotetext{
148 Arch. giur. Vol. LV, 1894, p. 506.

${ }^{149}$ Beiträge, III, 198, cit. por P. BONFANTE, Le singole cit. (nota 10 supra), p. 599.

${ }^{150}$ Le singole cit. (nota 10 supra), p. 599.

${ }^{151}$ Le singole cit. (nota 10 supra), p. 600.
} 
propriedade, parece totalmente estranha ao direito clássico e teve lugar unicamente na época romano-helênica do direito grego.

Todavia, o autor detecta que esse pressuposto foi ultrapassado por outros entendimentos, especialmente por V.F. PringSheIM, Der Kauf Mit fremdem Geld in Röm, Beitr. zur Rg. I, Leipzig, 1916 (cfr. MITTEIS, in Z. der Sav. St. für, Rg., 1916, vol. XXXVII, pp. 370-373), onde sugere que os que os principais textos, Inst., II, 1, §§ 40-43 (cfr. D., 41, 1, 9, 3; Gai, 2, 19 e Gai 2, 20) foram interpolados pelos compiladores.

\subsection{O título pro emptore em relação ao título putativo.}

P. BonfANTE sustenta que o princípio da emptio-venditio bonae fidei, não pode ser substituído pela opinio, pela existimatio, pelo error falsae causae, como se observa em Paulo, em D. 41, 4, 2 (pro emptore), e incidentalmente em Papiniano em D. 41, 8, 3 (pro legato), onde se verifica "non magis quam si quis emptum existimet quod non emerit ${ }^{152}$ ", e Justiniano nas suas Instituições, 2, 6, 11.

Esta é, para o autor, a principal iusta causa.

Ademais, os textos gerais, por exemplo, o fragmento D. 41, 3, 27 (De usurpationibus et usucapionibus), onde Ulpiano se refere à doutrina de Celso, e também em Africano, D. 41, 4, 11 (pro emptore), observando que a opinião "volgo tradita" exige o título verdadeiro e refere-se, na realidade, ao título pro emptore.

A respeito do fragmento de Ulpiano (D. $41,3,27)$ L. VACCA $^{153}$ declara ter a impressão de que, com a finalidade de deixar a redação mais genérica, alguém tenha efetuado no texto um trabalho de simplificação e abreviação da redação original.

O texto refere-se ao "de iure dotium" e foi inserido pelo próprio O. LENEL logo depois de D. 41, 9, 1, texto em que Ulpiano referia-se ao parecer de Juliano (possibilidade de usucapir ante nupcias as res dotales ofertadas), quando não ficasse claro para o adquirente que a vontade daquele que ofereceu o dote era no sentido de que a propriedade somente fosse transmitida após o casamento.

Conclui a escritora que Ulpiano aderia a esta opinião ao afirmar que "ante nuptias

\footnotetext{
${ }^{152}$ Como tampouco se alguém acreditasse ter comprado, aquilo que não tinha comprado.

153 "Iusta causa" e "bona fides" cit. (nt. 12 supra), p. 1.978.
} 
autem non pro dote usucapit, sed pro suo ${ }^{154, "}$

Segundo P. BONFANTE ${ }^{155}$ as melhores evidências da exigência do título verdadeiro são achadas em Paulo, em D. 41, 4, $2,2$.

Diz o texto que se for contratada uma compra e venda sobre condição suspensiva, durante o estado de pendência da condição o comprador não poderá jamais usucapir, tampouco se for considerada cumprida a condição.

O mencionado autor cita mais um exemplo, o qual é encontrado no texto de Paulo, D. 41, 4, 2, 6: "hai comperato lo schiavo Stico e per esso ti è stato tradito invece lo schiavo Dama. Non c'è, rispetto a Dama, compera veruna, onde, nonstante che qui l'errore può anche esser giustificatissimo, non è amessa punto l'usucapione ${ }^{156, "}$

Do exemplo citado conclui-se que o erro do comprador que recebeu o escravo Dama no lugar de Estico, não lhe dá o direito de usucapião, pois em relação ao escravo Dama não existiu compra alguma.

Todavia, observa P. BONFANTE ${ }^{157}$ que Paulo apresenta algumas importantes hipóteses que parecem adequar-se à admissão do título putativo, as quais são alvos de polêmica doutrinária.

A primeira hipótese refere-se ao fragmento D. 41, 4, 2, 8, onde Paulo trata da compra feita pelo tutor, de coisa da qual ele acredita que pertence ao pupilo:

"Tutor ex pupilli auctione rem, quam eius putabat esse, emit. Servius ait posse eum usucapere: in cuius opinionem decursum est eo, quod deterior causa pupilli non fit, si propius habeat emptorem, et, si minoris emerit, tutelae iudicio tenebitur ac si alii minoris addixisset: idque et a divo Traiano constitutum dicitur".
Um tutor comprou no leilão dos bens de um pupilo uma coisa que acreditava ser dele: Sérvio disse que pode usucapir-la, opinião que se tem acolhido, porque não prejudica o pupilo ter um mais próximo comprador de seus bens e que, se tivesse comprado por um preço menor que o devido, ele poderia responder por ação de tutela, <assim como> se tivesse adjudicado por preço menor aqueles bens para outra pessoa. Assim se diz que

\footnotetext{
${ }^{154}$ Antes do casamento não se usucape pro dote, mas pro suo.

${ }^{155}$ Le singole cit. (nota 10 supra), p. 601.

${ }^{156}$ Le singole cit. (nota 10 supra), p. 601.

${ }^{157}$ Le singole cit. (nota 10 supra), p. 601
} 
decidiu Trajano, de consagrada memória.

Na segunda hipótese, referente à lei D. 41, 4, 2, 9, em continuação à anterior, Paulo trata da compra feita pelo mandatário de coisa da qual ele acredita pertencer ao seu mandante.

"Procuratorem quoque, qui ex auctione, quam mandatu domini facit, emerit, plerique putant utilitatis causa pro emptore usucapturum. Idem potest dici et si negotia domini gerens ignorantis emerit propter eandem utilitatem".
Também o procurador que tiver comprado em leilão que, feito por encargo do mandante, acredita a maioria que por utilitatis causa, pode-se usucapir pro emptore. $\mathrm{O}$ mesmo se pode dizer, pela mesma razão, se tivesse comprado algo como gestor de negócios alheios sem conhecimento do interessado.

A dificuldade do caso decorre do fato que tutor e mandatário são, respectivamente, vendedores e compradores.

P. BONFANTE ${ }^{158}$ detecta que no caso do pupilo deve ser considerada a regra de Ulpiano, que considera que é nula a compra feita somente pelo tutor de coisa pertencente ao pupilo: "et emptoris et venditoris officio fungi non potest".

Observa, ainda, que R. StINTZING ${ }^{159}$ em relação aos fragmentos citados que neles se admite o próprio título verdadeiro ou o título putativo (a iusta causa usucapionis ou iusta causa erroris).

Não concorda, entretanto, com a opinião desse autor, e justifica que a correta interpretação deve ser justificada sobre uma consideração de duas espécies.

Para o citado jurista italiano, tutor e mandatário sabem muito bem que a compra e venda é nula e ainda que, por suposição, eles desconhecessem esse fato, a ignorância prossegue com um imperdoável erro de direito, onde não se teria, portanto, nem sequer uma iusta causa erroris.

Aliás, segundo o comentado autor, essa iusta causa erroris é o mínimo que exigem Nerácio, Africano e Pompônio, os maiores defensores do título putativo, logo, em relação a

\footnotetext{
${ }^{158}$ Le singole cit. (nota 10 supra), p. 602.

${ }^{159}$ Bona fides, p. 90, cit por P. BONFANTE, Le singole cit. (nota 10 supra), p. 601
} 
este título, o tex to não representa nada de relevante.

Ademais, como é cediço, a ignorância do fato não pode ser utilizada como desculpa pelo comprador no momento em que se tornar sabido que coisa foi obtida por erro ou mesmo que esta situação não seja identificada por ele.

Logo, se o usucapião foi concedido, isso significa que ele é justificado por iusta causa real, ou seja, deve ter sido constatada pelo menos uma prova evidente da ausência de lesão a terceiros.

Assinala P. BONFANTE ${ }^{160}$ que, nesse caso, pode até não existir uma compra e venda propriamente dita, mas existe algo que constitui todo o substrato natural ou social, o que significa dizer que a compra e venda existe como uma relação de fato, através da qual não só o pupilo e o mandante não venham a ser lesados (deterior causa pupilii non fit), como também pode se tornar viável que o tutor e o mandatário adquiram.

Adverte o citado autor que esta é uma relação singular e, portanto, admitida somente utilitatis causa, mas é uma iusta causa verdadeira.

Conclui-se, portanto, que essas soluções excepcionais adotadas pelos jurisconsultos romanos eram tomadas por razão de conveniência prática e para se atribuir uma solução definitiva àqueles problemas que não encontravam em nenhuma das iustae causae uma regra geral aplicável à espécie.

Entretanto, isso não pode significar, em nenhuma hipótese, que nesses casos os jurisconsultos estariam se rendendo aos defensores do título putativo.

Por essa razão é que se chega à conclusão que esta divergência não vai além do caso especial, pois se há a necessidade do reconhecimento de uma iusta causa possidendi, esta causa deve ser concebida como uma mera relação, a qual poderá fundamentar-se tão somente na inexistência da lesão.

\subsection{A compra e venda celebrada com incapaz.}

Afirma P. BONFANTE ${ }^{161}$ que ainda mais grave que as hipóteses analisadas anteriormente é aquela que se refere à compra e venda contratada com pessoa incapaz.

\footnotetext{
${ }^{160}$ Le singole cit. (nota 10 supra), p. 603.
} 
Os casos clássicos trazidos pela doutrina são os seguintes: a compra de uma res mancipi realizada de uma mulher sob tutela sem a auctoritas do tutor e com a auctoritas de um falso tutor, a compra de um impúbere e a compra de algo de um louco.

A primeira hipótese teve lugar no direito clássico, entretanto, embora tenha deixado de vigorar no novo direito é relevante para a compreensão dos demais.

É o caso da compra e venda de res mancipi efetuada com a mulher sob tutela.

Para elucidar o caso em comento P. BONFANTE ${ }^{162}$ adverte que uma vez reconhecida na consciência moral e jurídica do povo que a incapacidade da mulher e o instituto da tutela feminina não possuem uma base natural, essa premissa trouxe consequências no próprio direito positivo, sob a ação dúplice da jurisprudência e da jurisdição pretória em relação aos direitos do tutor e a ausência de sua auctoritas.

A liberação da mulher se dava através do ius liberorum, o qual foi igualmente abolido pela legislação imperial, entretanto, enquanto vigorou na legislação anterior, o negócio celebrado pela mulher sem a auctoritas não podia prevalecer, pois era considerado uma nulidade absoluta.

Em relação à venda com a auctoritas de um falso tutor, ensina o citado autor, os jurisconsultos da última idade republicana parecem ter reconhecido nessa compra e venda uma iusta causa usucapionis, desde que o comprador estivesse em boa-fé.

Isso não quer dizer que a existência de uma iusta causa usucapionis nesse caso não tenha sido colocada em dúvida, especialmente quando se observa a regra de que não era possível usucapir as res mancipi alienadas pela mulher sujeita à tutela agnatícia

Ademais, para Gaio (res furtiva), a vedação era absoluta.

Esclarece P. BONFANTE que não há dúvida que, desde aquela época, os jurisconsultos já haviam começado a discutir sobre o valor de uma compra e venda de res mancipi realizada cientemente com uma mulher, sem auctoritas do tutor ou com a auctoritas de um falso tutor.

Sua fundamentação é ilustrada com o seguinte caso, o qual foi decidido pelos jurisconsultos: um comprador não é um comprador de boa-fé, pois não tem título apto ao usucapião (iusta causa usucapionis), como se viu, não é a compra e venda pura e simples, mas a emptio-venditio bonae fidei.

${ }^{161}$ Le singole cit. (nota 10 supra), p. 603.
${ }^{162}$ Le singole cit. (nota 10 supra), p. 604. 
A decisão foi seguida tanto por Labeão, quanto por Sabino e Cássio.

Labeão, antes havia declarado que o comprador, em tal caso, não possuía pro emptore, mas sim, pro possessore, mas em sua escola começou-se a produzir uma interpretação mais ampla em relação a isso.

Próculo e Celso afirmaram que o adquirente possui pro emptore.

Observa P. BONFANTE ${ }^{163}$ que o comprador considera os frutos como seus a partir do momento que são percebidos com o consentimento do proprietário, o que significa dizer que a iusta causa não é inteiramente nula, mas tem valor como causa justificativa da aquisição dos frutos, semelhantemente à locação.

Ademais, se a mulher não pode alienar a propriedade de uma res mancipi, pode alienar livremente a posse.

Com base em uma constitutio Rutiliana, Juliano decidiu que o comprador poderia usucapir se tivesse pagado integralmente o preço à mulher, pois o pagamento do preço se constitui uma iusta causa verdadeira e suficiente à aquisição.

Assim, observa P. BonfAnte ${ }^{164}$ que como a venda é nula o usucapião não se pode fundar sobre ela e muito menos sobre uma falsa existimatio, porque o adquirente conhece toda a situação da coisa, desse modo, o pagamento do preço é que constitui o adquirente em uma verdadeira relação de não lesão à mulher e ao tutor e, consequentemente, justifica a posse e o usucapião.

Além disso, considerando que a compra e venda é nula, nesse caso a mulher não renunciou definitivamente à coisa, logo, poderia obtê-la novamente mediante a devolução da quantia que a ela foi paga.

Diferentemente dessa hipótese, no caso da venda realizada por pessoas incapazes (menores ou loucos) P. BONFANTE ${ }^{165}$ observa que a incapacidade dessas pessoas tem uma base natural, de tal modo que a nulidade do negócio firmado com tais pessoas aproxima-se muito da inexistência objetiva.

Todavia, entre esses dois casos há uma certa diferença de grau que faz com que esta base natural não produza a mesma intensidade em ambas as situações:

Observe-se o seguinte texto de Gaio: D. 44, 7, 1, 12 e 13:

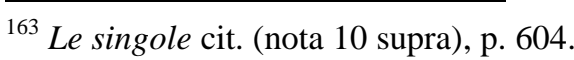


"Furiosum, sive stipulatur sive promittat, nihil agere natura manifestum est".

E o parágrafo seguinte:

"Huic proximus est, qui eius aetatis est, ut nondum intellegat, quid agatur: sed quod ad hunc benignius acceptum est: nam qui loqui potest, creditur et stipulari et promittere recte posse".
É claro que a estipulação ou a promessa feitas por um louco são nulas por natureza.
Este parece que não tem idade para entender o que faz, mas com relação a ele, se aplica isto com mais benevolência, pois se ele já pode falar, considera-se que pode estipular e prometer.

Primeiramente, deve-se ressaltar que a função da auctoritas tutoris é de possibilitar uma certa capacidade de consentir e de dar vida a uma relação voluntária que se reconhece no pupilo próximo à puberdade.

Conforme adverte P. BONFANTE ${ }^{166}$, a auctoritas integra a vontade do pupilo, acrescentando-a, mas não a substitui.

Para o mencionado romanista, os jurisconsultos romanos, em sua maioria, admitiam no caso de negócios obrigatórios pelo menos uma obrigação natural.

Portanto, no caso da compra e venda contraída com pupilo, sob o ponto de vista natural, essa relação, ainda que essa relação seja voluntária, não se poderia de nenhum modo ser chamada de nula.

Ela poderia produzir efeitos jurídicos, por exemplo, a condictio in quantum locupletior factus est pupilus, se o comprador tivesse efetuado o pagamento do preço.

Acentua P. BonfANTE ${ }^{167}$ que a bona fides ou a existimatio tem aplicação mais abrangente, mas não a ponto de substituir completamente a compra e venda.

Para o autor, talvez a primeira hipótese onde teria sido admitido o usucapião foi a compra e venda contraída sob falsa auctorictas, que é justamente a mais natural e equitativa, por duas razões: nela se verifica a facilidade do erro, e também a existência do dolo do qual o

\footnotetext{
${ }^{164}$ Le singole cit. (nota 10 supra), p. 605

${ }^{165}$ Le singole cit. (nota 10 supra), p. 605.

${ }^{166}$ Le singole cit. (nota 10 supra), p. 606.

${ }^{167}$ Le singole cit. (nota 10 supra), p. 606.
} 
comprador é vítima.

Pode-se extrair isso de um texto de Gaio, em D. 6, 2, 13, 2:

"Qui a pupillo emit, probare debet tutore auctore lege non prohibente se emisse. Sed et si deceptus falso tutore auctore emerit, bona fide emisse videtur".
Aquele que comprou de um pupilo deve provar que comprou com a autoridade do tutor e sem proibição legal. Mas se comprou enganado pela autoridade de um falso tutor, se entende que comprou de boa-fé.

Muito mais sensível à gravidade do caso é o texto de Paulo em D. 41, 4, 2, 15:

"Si a pupillo emero sine tutoris auctoritate, quem puberem esse putem, dicimusus ucapionem sequi, ut hic plus sit in re quam in existimatione: quod si scias pupillum esse, putes tamen pupillis licere res suas sin tutoris auctoritate administrare, non capies usu, quia iuris error nulli prodest".
Se eu tiver comprado de um pupilo sem a autoridade do tutor, pois acreditava que aquele já era púbere, diremos que procede o usucapião, de maneira que vale mais aqui $<0$ que se crê > do que a < a realidade >; mas se é sabido que é pupilo, mas você crê que os pupilos podem administrar suas coisas sem a autoridade do tutor, não poderá usucapir, porque $\mathrm{o}$ erro de direito não vale para ninguém.

$\mathrm{O}$ autor sustenta que provavelmente o inciso "ut hic plus sit in re" foi alterado por mero erro e o texto deveria dizer exatamente o contrário: isto é, que qui é maior o peso que se dá à crença subjetiva do que o peso da realidade.

Em seguida, P. BONFANTE ${ }^{168}$ adverte que Paulo não disfarça que em qui (hic) ele admite um desvio do princípio geral de Sabino, o qual determina que se deve atender menos aos elementos subjetivos da existimatio e da opinio e mais à substância e à realidade.

Para o autor, a consistência sutil desta iusta causa e a margem perigosa que ela deixa à bona fides eram do conhecimento de Paulo.

Em razão disso, pela primeira vez, permitiu-se invocar em matéria de usucapião aquele princípio que remete sempre aos defensores do título putativo: que o erro deve existir de fato, porque o erro de direito não é válido para ninguém (nulli prodest). 
Mas o fato de Paulo estar ciente disso, não nos autoriza supor que o jurisconsulto entendesse tão inusitadamente os seus princípios para autorizar, em qualquer caso, a troca livre da iusta causa usucapionis pela iusta causa erroris.

Ademais, sinaliza P. BonfANTE ${ }^{169}$ que Ulpiano, em D. 6, 2, 7, 4, refere-se de maneira mais simples à iusta causa na ação Publiciana, declarando que esta é cabível a quem compra de um menor ignorando esse fato.

Entretanto, em relação a este fragmento, o próprio autor duvida da autenticidade da decisão.

No que tange à compra e venda realizada por um louco, o contraste existente entre Paulo e Ulpiano é nítido.

Em Paulo, D. 41.4.2.16, verifica-se:

"Si a furioso, quem putem sanae mentis, emero, constitit usucapere utilitatis causa me posse, quamvis nulla esset emptio et ideo neque de evictione actio nascitur mihi nec publiciana competit nec accessio possessionis est".

Como se observa, tanto do ponto de vista civil, como do ponto de vista natural, a compra e venda celebrada com um louco é absolutamente nula.

Portanto, não é cabível para essa hipótese uma solução de caráter subjetivo, a exemplo da bona fides e do erro, pois a loucura é identificada objetivamente e não se refere a uma situação imaginária, logo, a lei não pode negar a este fato uma consequência.

Aduz P. Bonfante ${ }^{170}$ que não houve um contrato e, tampouco, se constituiu uma relação ex voluntate, mas se o negócio foi feito pode ser considerado fato jurídico e, por consequência, uma relação entre os supostos contratantes pode ser constituída.

Com base em D. 26, 8, 5 pr. o autor afirma que não se pode negar ao suposto comprador que desembolsou o preço da coisa a condictio, assim como não se poderia negar em relação ao caso do pupilo.

\footnotetext{
${ }^{168}$ Le singole cit. (nota 10 supra), p. 607.

${ }^{169}$ Le singole cit. (nota 10 supra), p. 607.

${ }^{170}$ Le singole cit. (nota 10 supra), p. 608.
}

Se eu tiver comprado de um louco que eu acredito estar em perfeito juízo, se admite utilitatis causa que posso usucapir, ainda que a compra seja nula e não tenha ação de evicção, nem me compete a Publiciana, nem a accessio possessionis. 
Todavia, esta relação faz com que possa se tornar viável também para o louco que o adquirente usucapa.

Como o comprador está em boa-fé, a ideia de lesão está distante de sua vontade, o que a remove por completo da realidade da situação.

P. BONFANTE ${ }^{171}$ identifica que nesse caso existe uma relação jurídica que não é iusta causa de compra e venda, pois ela está ausente, logo, a vontade aproxima-se muito do seu lado objetivo.

Por estas razões, o jurisconsulto romano é levado a reconhecer um ius singulare no domínio geral do instituto, inspirando-se na aequitas.

Sustenta o citado autor que não há dúvida que seja este o entendimento de Paulo.

Paulo está ciente do desvio dos princípios, tanto é que declara nula a compra e venda, mas, posteriormente, sustenta que a coisa foi admitida utilitatis causa e, por fim, não reconhece no caso nenhum dos efeitos obrigatórios e reais do contrato de compra.

Extrai desse entendimento o citado romanista, que é difícil estabelecer uma dedução lógica acerca das ideias de Paulo sobre o título verdadeiro, provavelmente, as ideias fossem tão amplas, que até mesmo Paulo e os demais defensores desse título admitiam a iusta causa erroris como equivalente da iusta causa usucapionis.

No entanto, esclarece P. BONFANTE ${ }^{172}$ que se até mesmo Paulo admite a iusta causa erroris no caso do usucapião, isso se atribui ao fato de que, na hipótese, ele a aplica para uma necessidade especial.

Desse modo, a solução aplicada por Paulo não seria suficiente como regra geral, uma vez que o próprio jurisconsulto nega a exsitência de uma iusta causa como essa.

Ela será sempre admitida utilitatis causa, não se admitindo a extensão de sua aplicação além dos limites por ela admitidos para o caso específico.

Portanto, observa P. BONFANTE ${ }^{173}$ quando a regra da aequitas é concebida como um princípio iuris singularis, esta deve restringir-se ao máximo à necessidade e à finalidade à qual é aplicada, ou seja, não se deve expandir a sua aplicação além do caso especial ao qual se destina.

${ }^{171}$ Le singole cit. (nota 10 supra), p. 608.

${ }^{172}$ Le singole cit. (nota 10 supra), p. 609.

${ }^{173}$ Le singole cit. (nota 10 supra), p. 609. 
O texto de Ulpiano é D. 6, 2, 7, 2:

"Marcellus libro septimo Digestorum scribit: eum, qui a furioso, ignorans eum furere, emit, posse usucapere: ergo et Publicianam habebit".
Marcelo, no livro sétimo Digestorum escreve: aquele que compra algo de um louco, ignorando que ele o é, pode usucapir; em consequência, terá também a ação Publiciana.

Como se observa, sem hesitação Ulpiano afirma a possibilidade de usucapião através da Publiciana.

Para P. BONFANTE ${ }^{174}$, nem por isso Ulpiano teria se referido à iusta causa usucapionis de um modo diferente ou mais amplo do que Paulo, a ponto de considerar esta decisão como um princípio anômalo.

Destaca o autor, que algumas considerações especiais de equidade moveram os jurisconsultos romanos a conceder usucapião àquele que tivesse adquirido de um louco.

Ademais, o princípio voltaria a ser aplicado com frequência pelos jurisconsultos, além dos referidos textos de Paulo e Ulpiano.

Nos demais textos, conclui o autor, este princípio é citado como uma regra tradicional, como se tivesse sido transmitido pelos jurisconsultos mais antigos.

Paulo, diz "constit" no texto citado, e "responsum est" em outro extraído de seus livros ad Plautium (D. 41, 3, 13, 1).

Entretanto, não obstante tais constatações, P. BonfANTE ${ }^{175}$ ressalta que em nenhum desses fragmentos os jurisconsultos falam de iusta causa, pois todos repetem simplesmente que se pode usucapir.

Outrossim, Ulpiano e Paulo, ao que se depreende da análise dos textos, decidem de modo quase idêntico em relação a formula que autoriza o usucapião àquele que adquire de um louco, ignorando esse fato.

\footnotetext{
${ }^{174}$ Le singole cit. (nota 10 supra), p. 610.

${ }^{175}$ Le singole cit. (nota 10 supra), p. 610.
} 


\subsection{A divergência em relação à Publiciana}

Em relação à Publiciana, ressalta P. BONFANTE ${ }^{176}$ que parece excessiva e também injustificada a inflexibilidade de Paulo.

Ainda que a regra seja de direito singular, a Publiciana se funda sobre o usucapião, com tendência até mesmo a ultrapassá-lo, tanto é que se uma especial ratio utilitatis aconselha ceder em um caso especial em relação aos requisitos do usucapião, esta tem mais valor em relação à Publiciana.

Portanto, para P. BONFANTE ${ }^{177}$, Paulo não deveria negar a Publiciana nem ao comprador e nem ao louco.

Se Paulo decidia dentro de uma ordem lógica e, ao mesmo tempo, não concordava com a accessio possessionis ou com ação obrigatória para a evicção, não deveria negar a Publiciana ao comprador e nem mesmo para o louco.

Mesmo porque, em relação a louco, a Publiciana poderia ser atacada pela exceptio iusti dominii.

Todavia, para o direito justinianeu, o autor verifica que prevaleceu o texto de Ulpiano, pelo menos para a opinião dominante, considerando que a tentativa de se conciliar os dois textos seria plenamente arbitrária.

Conclui o citado romanista que os casos em que Juliano, Paulo e Ulpiano remetem à compra e venda efetiva são espécies singulares, as quais são reguladas por princípios anômalos a serem aplicadas utilitatis causae ou referem-se a casos que, mesmo apresentando relações divergentes, partem do idêntico pressuposto da inexistência de lesão.

O mesmo se aplica a Sérvio, Marcelo, Pláucio, autores citados por eles nos textos.

Logo, a partir dessas hipóteses citadas, P. BonfANTE ${ }^{178}$, sustenta que elas estão longe de possibilitar uma livre interpretação do princípio geral, através do qual se exigia o título verdadeiro, mas sim, demonstram o rigor com este era compreendido e aplicado.

Provavelmente, o princípio não preservou o mesmo significado e conteúdo no direito justinianeu, mas essa afirmação autor salienta que deve ser objeto de investigação específica.

\footnotetext{
${ }^{176}$ Le singole cit. (nota 10 supra), p. 610.

${ }^{177}$ Le singole cit. (nota 10 supra), p. 610.

${ }^{178}$ Le singole cit. (nota 10 supra), p. 610.
} 


\section{Título pro legato}

Das iustae causae nominadas, resta a análise do título pro legato, pois em relação ao título pro herede, o autor não considera que ele seja uma verdadeira iusta causa usucapionis.

Acentua P. BONFANTE ${ }^{179}$ que o legado oferece a especialidade mais grave de todos os títulos, o que faz com que ele guarde uma importante distinção em relação a todas as iustae causae nominadas e inominadas: ao mesmo tempo que é modo de aquisição do domínio (pois não exige necessidade de manifestação por parte do legatário), é também ocupação ou tradição (por ser o legatário reconhecido como proprietário da coisa legada e ter direito a reivindicação).

Acrescenta, ainda, que na doutrina dos Proculeianos o legado era causa de aquisição de domínio, mas não era um modo pleno de aquisição, pois o legatário devia manifestar a vontade de adquirir, logo, a coisa seria dele apenas quando fosse cumprida essa condição.

No direito clássico, o legado considerado título de usucapião era aquele denominado per vindicationem.

O legado per damnationem não se apresenta como relevante à análise das iustae causae e do título putativo, em primeiro lugar porque ele não tinha o condão de conferir imediatamente a propriedade e, em segundo lugar, porque ele não era uma iusta causa do domínio (causa próxima), logo, não podia sequer representar uma iusta causa de usucapião.

Nessa espécie de legado, esclarece P. BonfANTE ${ }^{180}$ que a iusta causa de aquisição do domínio e do usucapião ocorria na solutio da obrigação realizada em favor do herdeiro, assim, o que era conferido era apenas um direito de obrigação.

Todavia, assim como o legado per vindicationem, o legato per damnationem passa a ser causa e modo de aquisição do domínio somente no direito justinianeu, quando as várias espécies de legado foram reunidas em apenas uma.

Os textos de Papiniano, Paolo e Ulpiano confirmam a necessidade da verdadeira existência de um legado verdadeiro para consituir a possessio e a usucapio pro legato.

Ulpiano, D. 41, 8, 1:

\footnotetext{
${ }^{179}$ Le singole cit. (nota 10 supra), p. 611.

${ }^{180}$ Le singole cit. (nota 10 supra), p. 612.
} 
"Legatorum nomine is videtur possidere cui legatum est; pro legato enim possessio et usucapio nulli alii quam cui legatum competit”.

Paulo, D. 41, 8, 2:

"Si possideam aliquam rem, quam putabam mihi legatam, cum non esset, pro legato non usucapiam it".

Papiniano, 41, 8, 3:

"Non magis quam si quis emptum existimet, quod non emerit".
Se entende que possui por legado, o legatário, pois a posse e usucapião pro legato não compete a ninguém mais que o legatário.
Se possuo alguma coisa, acreditando que me havia sido legada, mas não sendo, não poderei usucapir-la pro legato.

Para que seja realizada a aquisição pro legato, não basta apenas a capacidade jurídica geral, é necessária também uma capacidade especial subjetiva (testamenti factio com o falecido).

A característica fundamental que faz da causa legati um modo de aquisição, acaba acarretando consequências de ordem prática e teórica.

Segundo o autor, o legado é uma iusta causa, porém, para o usucapião e para a Publiciana, e não para a tradição, isso porque, a verdadeira tradição no caso do legado nunca existirá.

Um pressuposto lógico para a realização do usucapião é que tenha havido a posse e, em regra, essa posse necessariamente exigiria um momento inicial, a imissão.

Entretanto, essa imissão na posse não é verdadeiramente uma tradição.

O mesmo ocorre com o concurso de herdeiros e também poderia acontecer independentemente dele.

Em Papiniano, D. 41, 8, 8 (também em D. 21, 3, 1, 5), verifica-se a seguinte hipótese: 
"Si non traditam possessionem ingrediatur sine vitio legatarius, legatae rei usucapio competit”.
Se o legatário tinha entrado sem vício na posse que não lhe chegou a ser entregue, compete o usucapião de coisa legada.

Observa P. BONFANTE ${ }^{181}$ que esta situação traz desdobramentos de ordem lógica.

Se o legado, em si, é modo de aquisição de propriedade, em regra, não se pode considerá-lo perfeito enquanto não ocorree a aquisição, logo, nessa situação o usucapião se faz necessário.

Em relação ao legado per vindicationem, quando se tratasse de coisas não fungíveis, a coisa legada deveria estar no domínio quiritário do testador também no momento da confissão do testamento.

Este princípio foi firmado pelos jurisconsultos clássicos.

Adverte P. BONFANTE ${ }^{182}$ que essa situação acarreta uma consequência prática relevante, pois nela, tem-se um negócio nulo, entretanto, é considerado título verdadeiro de usucapião.

Por mais peculiar que seja essa conjectura, o autor esclarece que esse entendimento bem aceitável, haja vista que este conceito conduz novamente à ideia de que a iusta causa não é negócio geral de aquisição.

Ela exprime, essencialmente, a renúncia da coisa em favor do adquirente e o reconhecimento da ausência de lesão.

Portanto, não importa que o legado seja nulo como modo aquisição, pois não será como iusta causa de usucapião.

Tomando como referência a ideia que os romanos tinham da iusta causa, não seria inadequada a admissão do usucapião mesmo quando a coisa legada fosse uma res aliena.

É o que determina Paulo na primeira parte do fragmento D. 41, 8, 4:

\footnotetext{
"Pro legato potest usucapi, si res aliena Pode-se usucapir pro legato, quando foi legata sit (...)” legada uma coisa alheia (...).
}

\footnotetext{
${ }^{181}$ Le singole cit. (nota 10 supra), p. 613.

${ }^{182}$ Le singole cit. (nota 10 supra), p. 613.
} 
A confusão que foi gerada pelos doutrinadores decorre da negação do valor da iusta causa, diante de um parecer tão contundente como o de Paulo.

Alguns autores defendem a ideia de que o título per vindicationem de coisa alheia não poderia ser título de usucapião.

Entretanto, P. BONFANTE ${ }^{183}$ observa que Paulo não poderia ter se referido a um legado per damnationem, pois nesse caso, o título seria a solutio.

Dois fragmentos referem-se a este caso típico, o primeiro de Javoleno e o segundo de Pompônio.

Em relação a esses fragmentos P. BonfAnte afirma que I. ALIBRANDI, R. STINTZING e C. ApPleton, equivocadamente, posicionam-se no sentido da admissão de um legado putativo $^{184}$.

Javoleno, em D. 41, 8, 5:

"Ea res, quae legati nomine tradita est, quamvis dominus eius vivat, legatorum tamen nomine usucapietur."

Pompônio, em D. 41, 8, 6:

"si is cui tradita est, mortui esse existimaverit."

$\mathrm{O}$ autor identifica que a hipótese trata do caso uma res aliena que foi efetivamente legada, mas o verdadeiro proprietário, que não é o testador, é ainda vivo.

Nesse caso, o título foi produzido pelo testador não proprietário, mas verdadeiramente morto, portanto, o usucapião começa a correr a partir do momento que o credor acredita que a coisa realmente pertencia ao falecido e autor do testamento.

Portanto, conclui P. BONFANTE, mais uma vez nota-se que ele estava em boa-fé e pelo fato de estar em boa-fé é que se torna possível o usucapião.

Em decorrência da sua natureza de ato mortis causa, surge outro incidente a respeito

\footnotetext{
${ }^{183}$ Le singole cit. (nota 10 supra), p. 614.

${ }^{184}$ I. Alibrandi, Possesso, p. 118; R. Stintzing, Bona fides, p. 92; C. ApPleton, Publicienne, 1, p. 306, nota
} 
desse título.

P. BONFANTE ${ }^{185}$ apresenta a seguinte hipótese: uma coisa foi efetivamente legada no testamento, mas, sucessivamente, em codicilos. Em parte, o legado é retirado ou, de outro modo, o testador não deu em legado a um pretenso legatário, mas a outro de nome idêntico.

Com base nessa hipótese o autor formula a seguinte indagação: "se io ignoro che um codicillo $m$ 'ha tolto il beneficio, se ignoro l'esistenza del mio omonimo o altrimenti credo d'esser io la persona onorata dal testatore, potrò usucapire? ${ }^{186}$,"

$\mathrm{O}$ autor responde que em ambas as espécies o direito justinianeu reconhece o usucapião, todavia, na idade clássica essa ideia não parecia ser uníssona.

No primeiro caso extraído da compilação justinineia, Paulo (D. 41, 8, 4), de maneira despreocupada parece admitir a existência de uma iusta causa suficiente ao usucapião, mas, segundo Hermogeniano (D. 41, 8, 9), este é um dos casos onde o usucapião foi admitido depois de longas divergências.

P. BONFANTE ${ }^{187}$ explica que, aos romanos, ignorar os codicilos era bastante comum.

Frequentemente, nas fontes, narra-se o caso da descoberta e produção de codicilos que permaneceram por longo tempo ocultos, o que teria gerado um desvio bastante grave ao conceito da iusta causa.

No segundo caso, Paulo avança com um pouco mais de hesitação: "Idem potest dici, etc..

O autor ressalta que, indevidamente, na hipótese defendida por R. STINTZING, o que se propõe é um relaxamento extremo da boa-fé, argumentado pela natureza meramente negativa dela.

Com base nas fontes, o autor conjectura a seguinte indagação: se alguém que possui um nome que ninguém contesta, estando em perfeita boa-fé, pode acreditar ser ele o legatário, ignorando a existência de outra pessoa com o mesmo nome?

P. BONFANTE ${ }^{188}$ esclarece que para que os textos pudessem fornecer alguma saída, seria necessário algo mais para justificar o erro do pretendido legatário, e consequentemente

42, cit. por P. BONFANTE, Le singole cit. (nota 10 supra), p. 614.

${ }^{185}$ Le singole cit. (nota 10 supra), p. 615.

${ }^{186}$ P. BONFANTE, Le singole cit. (nota 10 supra), p. 615.

${ }^{187}$ Le singole cit. (nota 10 supra), p. 615.

${ }^{188}$ Le singole cit. (nota 10 supra), p. 615. 
constituí-lo em boa-fé. Caso contrário, seria apenas um jogo de presunções.

\subsection{A admissão do usucapião com base em um legado nulo}

O legado pode ser nulo por um vício na concessão, por exemplo, um vício formal.

O citado por Hermogeniano (D. 41, 8, 9), além de outro relacionado à ademptio legati "post magnas varietates obtinuit", poderia induzir tal conclusão.

A impressão que ostenta P. BONFANTE ${ }^{189}$ é que neste caso havia uma iusta causa a domino, portanto, deve-se reconhecer o usucapião para, posteriormente, poder justificar a posse com base em um legado feito sob a forma da in bonis.

Todavia, novamente a situação apresenta a ausência da iusta causa.

Ademais, a hipótese não demonstra qualquer preocupação com relação ao fato do alienante ser ou não proprietário, tampouco revela a ausência dos momentos necessários à aquisição.

$\mathrm{Na}$ verdade, o caso trata da própria renúncia, contudo, ela não vem expressa na forma que a lei determina e, por não ter atendido as devidas formalidades, a lei não reconhece essa relação com o alienante.

A situação é análoga à da doação, quando não foram obedecidos os limites fixados pela lei.

Observa P. BONFANTE ${ }^{190}$ que o Pretor poderia ter sancionado uma iusta causa configurada nesse modelo, para consequentemente incluí-la entre as causas da in bonis, mas não era o costume da época usar desses meios para promover as alterações.

O vício na iusta causa é mais grave, por isso não poderia ser reconhecido, exceto quando o uso das formas antigas era deixado de lado e o foco desviava-se à existência da vontade.

Um texto sobre o título pro legato que, segundo P. BONFANTE ${ }^{191}$, realmente parece admitir o título putativo é o D. 41, 10, 4, 2, de Pompônio:

\footnotetext{
${ }^{189}$ Le singole cit. (nota 10 supra), p. 616.

${ }^{190}$ Le singole cit. (nota 10 supra), p. 616.

${ }^{191}$ Le singole cit. (nota 10 supra), p. 617.
} 
"Quod legatum non sit, ab herede tamen perperam traditum sit, placet a legatario usucapi, quia pro suo possidet.”
O que o herdeiro entregou equivocadamente, sem ter sido legado, se admite que possa usucapir-lo o legatário, que o possui pro suo.

Por suposição, se no direito clássico este fragmento fizesse alusão a um caso de legado per damnationem de coisa mancipi, onde o herdeiro tivesse recebido em tradição, como sugere A. PERNICE ${ }^{192}$, uma vez que Pompônio parecia não conhecer a denominação específica pro soluto, poderia o legatário usucapir, porque possui pro suo.

No caso em análise, o legado tem a eficácia do antigo legado per vindicationem, onde se verifica um usucapião com base na falsa existimatio, todavia, no direito justinianeu ele assume um significado mais grave.

Assinala P. BONFANTE ${ }^{193}$ que a existência de uma relação comum entre legatário e herdeiro, onde este não acredita que tenha sido lesado e o fato do erro ter sido também compartilhado pela outra parte, provavelmente foi o que teria induzido à construção desta iusta causa usucapionis.

Além do mais, deve ser ressaltado que o transmitente não tinha a intenção de pagar, mas deveria, pois há solutio, logo, a consequência do que dispõe o fragmento é justamente aquela que marca o erro escusável, exatamente como se pretende no título putativo.

Destarte, conclui o autor que o ecletismo singular dos compiladores o re esultado de um ato involuntário de inobservância das reformas realizadas no instituto do legado, fizeram surgir no novo direito, ao lado do título verdadeiro, uma verdadeira causa erroris baseada na limitação da escusabilidade, ou seja, um título exclusivamente putativo.

\section{Títulos inominados}

P. BONFANTE ${ }^{194}$ define como títulos inominados as justas causas menos frequentes, as quais incidentalmente aparecem nas fontes com referência à Publiciana ou ao usucapião.

Segundo o autor, ante a inexistência de uma denominação específica, os jurisconsultos

\footnotetext{
${ }^{192}$ Labeo, II, 1, 1895, p. 403-404.

${ }^{193}$ Le singole cit. (nota 10 supra), p. 617.

${ }^{194}$ Le singole cit. (nota 10 supra), p. 618.
} 
romanos procuraram incluí-los entre as espécies de iustae causae já existentes, ora encaixando-os como título pro emptore, ora resumindo-o com a designação genérica pro suo.

Primeiramente, cita aqueles incluídos na designação pro emptore: a litis aestimatio, a permuta, a noxae deditio (mesmo na figura de ductio noxalis) e, genericamente, as iustae causae pretórias de imissão na posse de bens alheios como a transação, a adjudicação, a divisão e outras que não possuem tampouco uma designação específica.

Em relação à sentença e ao juramento, o citado romanista salienta que não as considera iustae causae.

Para ele, uma das mais importantes é a litis aestimatio.

Majoritariamente, nas fontes, cita-se a semelhança dela em relação à compra e venda ou conclui-se que após a litis aestimatio, se começa a possuir pro emptore.

A litis aestimatio é movida contra com o proprietário verdadeiro visando a aquisição da propriedade ou pelo menos da in bonis e, por consequência, caberá uma in rem actio ou uma exceptio contra aquele que moveu a ação ${ }^{195}$.

Em relação à permuta, dada a sua semelhança com a compra e venda, os Sabinianos foram induzidos a torná-las um só conceito.

Ela somente é tratada de forma autônoma, alheia à compra e venda, no título da ação Publiciana $^{196}$.

Todavia, adverte o autor, a permuta somente será classificada como iusta causa em favor da parte que receber a coisa primeiro, pois, a outra parte, a qual receberá como troca e pagamento, uma vez reconhecido o contrato e a obrigação, usucapirá na forma pro soluto, se a res for aliena.

P. BONFANTE ${ }^{197}$ cita ainda que, assim como a permuta, são iustae causae as outras dações para a constituição de contratos inominados, mas elas devem ocorrer antes que se torne legal a obrigação à contraprestação.

Quanto à noxae dedictio, ressalta que ela é lembrada mais de uma vez como causa justificativa do usucapião, da Publiciana ou da posse civil nas fontes e, ainda, em uma

\footnotetext{
${ }^{195} \mathrm{O}$ autor faz referência aos fragmentos D. 25, 2, 22 pr., de Juliano, D. 41, 4, 1 de Gaio, D. 41, 4, 3 de Ulpiano e D. 6, 1, 26 de Paulo.

${ }^{196} \mathrm{O}$ texto é D. 6, 2, 7, 5 de Ulpiano.

${ }^{197}$ Le singole cit. (nota 10 supra), p. 618.
} 
passagem de Paulo é citada na maneira usual: pro noxae deditio ${ }^{198}$.

A ductio noxalis, assim como as outras causas pretórias de imissão na posse são apenas causa de posse, mesmo se constituída em relação ao proprietário verdadeiro.

É desnecessário recordar, adverte P. BonfAnTE, que quando a ductio for cabível diante do proprietário verdadeiro, a posse assume figura da in bonis.

$\mathrm{O}$ autor menciona também a transactio, a qual era expressamente reconhecida pelo imperador Diocleciano em um título do Codex e incidentalmente recordada como iusta causa de usucapião por Pompônio ${ }^{199}$.

De resto, ela era intitulada igualmente como a compra e venda e a transação.

A adiudicatio é mencionada por Ulpiano entre as iustae causae da ação Publiciana ${ }^{200}$.

Com base nesse título, Marcelo, em D. 41, 3, 17, apresenta uma espécie de usucapião:

"Si per errorem de alienis fundis quasi de communibus iudicio communi dividundo accepto ex adiudicatione possidere coeperim, longo tempore capere possum".
Se eu tiver iniciado a posse pela adjudicação em um juízo de divisão de coisa comum sobre imóveis alheios tomados por erro como comuns, posso adquirir a propriedade pela $<$ posse $>$ de longo tempo.

Assim como o legado, a adiudicatio é também um modo de aquisição do domínio.

Além das já analisadas iustae causae nominadas e daquelas aqui mencionadas, Juliano apresenta outra hipótese em D. 41, 3, 33, 3:

"Si mihi Titius, a quo fundum petere volebam, possessione cesserit, usucapionis causam iustam habebo. Sed et is, a quo ex stipulatu fundum petere volebam, cedendo mihi possessione, si solvendi causa id fecerit, eo ipso efficiet, ut fundum longo tempore capiam".
Se Tício, de quem eu queria reclamar a propriedade de um imóvel tiver me cedido a posse do mesmo, terei uma justa causa para usucapir-lo; também aquele de quem eu queria reclamar um imóvel por causa de estipulação, se me cede sua posse com intenção de pagamento, faz com isso que eu possa adquirir a propriedade do imóvel pela <

\footnotetext{
${ }^{198}$ Os textos são D. 9, 4, 28, de Africano, D. 6, 2, 5, de Ulpiano e D. 41, 2, 3, 21 de Paulo.

${ }^{199}$ Fragmentos C. 7, 26, 8 e D. 41, 3, 29.

${ }^{200}$ D. $6,2,7,1$.
} 
posse > de longo tempo.

No caso narrado, falta a aliquid datum, aliquid retentum, logo, não se tem uma transação.

Entretanto, P. BONFANTE ${ }^{201}$ esclarece que, inegavelmente, conforme se detecta no fragmento, existe entre o possuidor e Tício uma relação de natureza análoga, pois Tício abandona a posse para não ser perturbado e, como consequência, concorda em testemunhar cada fato em relação à hipótese.

Logo, Tício consentiu em despir-se da coisa em favor do possuidor, o que caracteriza a evidente relação de não lesão.

Embora não seja fácil encontrar uma rubrica específica para denominar essa causa, o autor sustenta que não se pode negar a existência de uma iusta causa adquirendi.

Adverte, ainda, que a dúvida em relação a isso pode e deve ter nascido apenas da alegação inconsciente que possuem os modernos, em detrimento dos romanos, de imaginar ter exaurido todo o campo dos negócios possíveis.

A admiração pela forma com a qual procediam os jurisconsultos romanos, pode ser observada nas palavras do próprio P. BonfANTE ${ }^{202}$ : “forse i Romani erano insieme più modesti e più accorti; essi vivevano in un diritto continuamente svolgentesi, e come "l'aequitas" era per loro lo spirito perennemente vivo della giustizia nell'evoluzione giuridica, così abbiamo pure da loro la candida confessione che i negozi sono più assai dei vocaboli, conforme alla natura delle cose; onde, quando ne incontrano o ne ammettono uno nuovo, dicono che è c'è una causa, o una giusta causa, como nel caso presente

\subsection{O juramento e a sentença}

Em relação ao juramento e à sentença, o autor sustenta categoricamente que não os considera iusta causa usucapionis.

Quanto ao juramento, existem posições favoráveis e desfavoráveis à classificação do

\footnotetext{
${ }^{201}$ Le singole cit. (nota 10 supra), p. 620.

${ }^{202}$ Le singole cit. (nota 10 supra), p. 621.

${ }^{203}$ P. BONFANTE, Le singole cit. (nota 10 supra), p. 621.
} 
instituto como iusta causa.

A posição favorável costuma citar algumas frases gerais, as quais foram escritas por autores que comparam o juramento à transação ou à coisa julgada ${ }^{204}$, especialmente a um obscuro texto de Ulpiano, onde o jurisconsulto se refere ao pensamento de Juliano (D. 12, 2, $13,1)$.

Por outro lado, a posição contrária ${ }^{205}$ baseia-se na relatividade do juramento, sobre o fato desse ato processual não ser um modo de aquisição do domínio e, igualmente, sobre o silêncio das fontes em relação a essa questão.

Em relação a este último argumento, tendo em vista seu caráter extrínseco e a impossibilidade de se desenvolver qualquer raciocínio sobre ele, P. BONFANTE ${ }^{206}$ entende que não deve ser levado em consideração.

Entretanto, no que tange à tese que parte da relatividade inflexível do juramento e da sua natureza jurídica, sugere o autor que ele não deve ser enquadrado no grupo das causas reais ou das causas genéricas.

Isso porque a relação que concebe o juramento, não pode ser classificada como um vínculo obrigatório, pois a sua função é apenas de justificar uma relação pessoal entre aquele a quem se refere e aquele que o prestou.

Segundo o autor, aquele que jura, manifesta e justifica a negação do seu direito sobre a coisa através renúncia em favor do outro, em síntese, ele exclui-se da coisa, logo, a justa causa real é uma relação de não lesão com a pessoa do proprietário verdadeiro ou presumido.

Todavia, a causa obrigatória é uma relação semelhante, mas com qualquer pessoa e justifica unicamente a renúncia à própria livre atividade em relação a determinados eventos.

Para P. BONFANTE ${ }^{207}$, o juramento é apto a justificar uma obrigação entre aquele a quem se remete e aquele que o presta. Aquele que faz o juramento se expõe e vê se ser aniquilada a prova do seu direito em relação ao direito da outra parte.

$\mathrm{O}$ autor do juramento poderia alegar, todavia, que prefere insurgir contra o adversário por meio de uma exceção ou ele poderá fornecer provas contra ele mesmo, ao invés de ser

\footnotetext{
${ }^{204}$ Especialmente, o fragmento D. 12, 2, 2.

${ }^{205}$ Pertencem a esta corrente B. WindSCHEID, Pand., I, § 179, C. APPLETon, Publicienne, I, § 198, pp. 351 e ss, C. BERTOLINI, Il giuramento nel diritto romano, Roma, 1886, p. 139, cit. por P. BONFANTE, Le singole cit. (nota 10 supra), p. 622.

${ }^{206}$ Le singole cit. (nota 10 supra), p. 622.

${ }^{207}$ Le singole cit. (nota 10 supra), p. 622.
} 
julgado desfavoravelmente por falta de prova.

Explica P. BONFANTE que "egli lo sa e, si può dire, lo vuole, nel senso che preferisce avere spuntata la propria arme, l'azione, di fronte all'avversario per via di un'eccezzione, o esser lui stesso a fornire um'arma d'offesa a costui piuttosto che venir respinto per insufficienza di prove 208 ,".

Segundo o citado autor, o ato que ele realiza é de limitar a sua livre atividade, obrigando-se a um non fare, sobre pena de se submeter à exceptio iurisiurandi, ou a fare, caso prentenda ficar insuscetível à ação que ele mesmo teria fornecido a base.

Afastando do ato a presunção de renúncia absoluta sobre a coisa, quanto ao fato de ser iusta causa real, certamente faltará um atributo essencial: o título deve fazê-lo presumir dominus da coisa.

Aduz o mencionado romanista que o desdobramento lógico que se teria, consequentemente, será que a parte que prestou o juramento, para fornecer a prova da plena validade da sua iusta causa, deverá demonstrar ter jurado em falso, o que seria absurdo.

Portanto, assinala P. BONFANTE ${ }^{209}$ que atribuir ao juramento a eficácia de iusta causa implica em não distinguir na aquisição o momento justificativo, o qual é representado pela negação ou exclusão do direito alheio, ou seja, daquilo que constitui a iusta causa: a ausência de lesão a outrem.

Justifica o autor que aquele a quem se destina o juramento, não pode se considerar dominus, pois, na melhor das hipóteses, ele teria que dizer que acreditava-se como tal, desse modo, o juramento passaria a ser um título que cada um obtém por si mesmo.

Isso seria inconcebível, além do mais, seria a personificação absoluta do princípio romano que determina que ninguém pode constituir a si mesmo a causa da própria posse.

Segundo P. BONFANTE ${ }^{210}$, esse resultado é confirmado pela exegese dos textos da seguinte maneira:

Se o objeto do juramento é uma relação obrigatória, isso irá gerar contra aquele que o recebeu uma ação ou exceção, as quais seriam asseguradas em favor daquele que jurou, por exemplo, se a mulher jurou ter constituído em dote, caberá ação de repetição ${ }^{211}$, logo, o

\footnotetext{
${ }^{208}$ Le singole cit. (nota 10 supra), p. 622.

${ }^{209}$ Le singole cit. (nota 10 supra), p. 623.

${ }^{210}$ Le singole cit. (nota 10 supra), p. 623.

${ }^{211}$ É o caso narrado no fragmento de Paulo, D. 12, 2, 30, 2.
} 
juramento dará início à obrigação ou a extinguirá.

Mas se o juramento tem por objeto um direito real, por consequência a eficácia do ato se apresenta de modo singular e característico.

Se o possuidor jurou que a coisa é sua, as fontes declaram que é cabível uma actio (actio in factum ou a actio Publiciana ${ }^{212}$ ), salvo se a ação se dirigir somente contra aquele ao qual se referiu o juramento.

Em relação àqueles que sustentam a posição favorável à admissão do juramento à condição de iusta causa, o autor em comento cita um único argumento que para ele parece ser verdadeiro: refere-se ao fragmento de Ulpiano, D. 12, 2, 13, 1:

"Iulianus ait eum, qui iuravit fundum suum esse, post longi temporis praescriptionem etiam utilem actionem habere debere".
Disse Juliano, que aquele que jurou que um imóvel era de sua propriedade, deverá ter a ação útil ainda que tenha transcorrido a longi temporis praescriptio.

Depois do decurso da longi temporis praescriptio, quem prestou o juramento ainda possui uma ação para recuperar a coisa, portanto, o juramento é considerado título de aquisição, haja vista que se exige o título e a boa-fé para o usucapião e também para a longi temporis praescriptio.

Quanto ao direito clássico e à época de Juliano, cabe analisar se a longi temporis praescriptio também assegurava uma ação.

No título do juramento actio utilis, designa-se a ação que o juramento admite, por exemplo, em D. 12, 2, 11, 3 e em D. 12, 2, 13, 5, extraídas do mesmo livro de Ulpiano.

Deve-se verificar, ainda, se a actio utilis deveria se referir a uma outra ação útil produzida pela longis temporis praescriptio, a qual se cumpriria sobre a base desta alegada iusta causa.

\subsection{A actio utilis e a longi temporis praescriptio}

Não pareceria compreensível que após o decurso da longi temporis praescriptio,

\footnotetext{
${ }^{212}$ Refere-se aos textos de Ulpiano, D. 12, 2, 9, 7, D. 12, 2, 11, 1, e D. 6, 2, 7, 7, os dois primeiros relacionados à actio in factum e o terceiro à actio Publiciana, e o texto de Paulo, D, 6, 2, 12, 2, relacionado à actio Publiciana.
} 
aquele que jurou ainda tivesse à sua disposição uma actio utilis.

Para desvendar essa hipótese, P. BONFANTE ${ }^{213}$ responde que essa situação somente será admissível caso a primeira ação útil seja somente contra o deferente, pois, depois de transcorrida a prescrição aquisitiva, ela poderá ser usada contra qualquer um.

Outra questão que inquieta o citado autor, refere-se à razão pela qual Juliano e Ulpiano não advertiram que se trata de uma ação útil diversa.

Seu entendimento é que, para qualquer interpretação divergente, é necessário fazer referência à parcela etiam alla longi temporis praescriptio, e não à ação.

Na opinião do autor, SAVIGNY ${ }^{214}$ apresentou uma opinião que não é bem sucedida do lado prático e, tampouco, do lado exegético.

Para este jurista, estaria decorrida em favor do possuidor a longi temporis praescriptio a partir do primeiro momento que existisse uma ação contra ele.

Mas com esse possuidor, ao invés de opor-se a ela ou pelo menos esperar que o autor provasse o seu direito, surge outra decisão que defere o juramento.

Assim, entende SAVIGNY, não obstante a longi temporis praescriptio decorrida, o agente consegue uma ação (utilem actionem), já que ao fazer o juramento sobre a propriedade o possuidor implicitamente renunciou à prescrição.

Para P. BONFANTE ${ }^{215}$, mais acatável é a interpretação de R. POTHIER, acolhida, em geral, pelos franceses, entre eles C. PELlat e C. APPLETON ${ }^{216}$.

Observa o autor que o agente jurou antes do cumprimento da longi temporis praescriptio pelo possuidor, logo, pode intentar a sua ação mesmo depois do cumprimento dela, pois o juramento interrompeu o seu curso, assim como seria com a litis constestatio.

Mas se o juramento interrompe a prescrição, não parece correto que se fale do cumprimento de uma prescrição que cessou de decorrer.

P. BONFANTE ${ }^{217}$ abstém-se de outras interpretações e adota a opinião de O. LENEL ${ }^{218}$, a qual sugere que Ulpiano não pode ter escrito dessa forma, já a opinião de R. POTHIER, acolhida por C. PELlat e C. APPLETON trafega no sentido de que não é possível desvendar

\footnotetext{
${ }^{213}$ Le singole cit. (nota 10 supra), p. 625.

${ }^{214}$ System, II, $\$ 311$, p. 68 , (trad. it. p. 89) cit. por P. BONFANTE, Le singole cit. (nota 10 supra), p. 625.

${ }^{215}$ Le singole cit. (nota 10 supra), p. 625.

${ }^{216}$ Publicienne, I, pp. 354-356.

${ }^{217}$ Le singole cit. (nota 10 supra), p. 626.
} 
aquilo que Ulpiano realmente escreveu.

Avançando em uma conjectura mais simplista, o romanista italiano sugere que talvez, no texto originário, Ulpiano dissesse post usucapionem etiam, ou ainda, post usucapionem quoque.

A consideração final de P. BONFANTE ${ }^{219}$, é que no tempo de Juliano, não havia qualquer vestígio da existência da longi temporis praescriptio, mas, ainda que se pretenda considerar essa hipótese como válida, provavelmente Juliano e Ulpiano referiam-se a um imóvel provincial.

Acrescenta o autor que, talvez, o que teria provocado os compiladores a transformar a usucapio em longi temporis praescripio foi justamente a menção a um imóvel.

Destarte, com base nos fragmentos de Paulo, D. 41, 4, 2, 21, Marcelo, D. 41, 6, 2, Ulpiano, D. 6, 1, 17, 1 e Gaio, D. 6, 1, 18 e 20 , conclui-se que o usucapião não é interrompido pela litis contestatio, portanto, continua também a decorrer após o juramento.

\subsection{A eficácia da coisa julga}

Assim como o juramento, para P. BONFANTE ${ }^{220}$, ainda que grande parte da doutrina se manifeste em posição divergente, a sentença judicial também não deve ser considerada iusta causa usucapionis, por razões semelhantes.

Para o autor, se é possível sustentar que a eficácia da coisa julgada como título de usucapião decorra da decisão judicial, precisa-se identificar quem teria atribuído ao juiz este poder.

Ela não teria outra faculdade, senão a de reconhecer a existência do direito do agente contra o réu e determinar a devolução da coisa, pois a sentença é declarativa e não constitutiva de direitos.

Logo, se uma terceira pessoa decide mover uma ação contra o mesmo agente, um novo juízo será instaurado e poderá se ver condenado nessa nova ação, aquele que primeiramente tinha se saído vencedor.

\footnotetext{
${ }^{218}$ Palingenesia, Ulp. 673, cit. por P. BONFANTE, Le singole cit. (nota 10 supra), p. 625.

${ }^{219}$ Le singole cit. (nota 10 supra), p. 627.

${ }^{220}$ Le singole cit. (nota 10 supra), p. 627.
} 
Esclarece o citado romanista, que nos casos expressamente determinados pelo legislador (juízos divisores), tem-se uma situação onde a decisão tem valor de título e modo de aquisição, consistindo em um bom argumento contra o valor limitado dela.

É um novo poder que permite ao juiz a possibilidade de conferir a adjudicação.

Extrai-se dessa ideia, a dúvida porque nunca fora concedido ao juiz este poder anteriormente, considerando que a adiudicatio é título e modo de aquisição.

P. BONFANTE ${ }^{221}$ sustenta autor e réu, para benefício comum e sem lesão a alguém, vindo a excluir reciprocamente da propriedade a parte dividida um a favor do outro, são ou serão presumidos efetivamente proprietários, desse modo, podem considerar-se como autor um e outro.

Apenas um texto pode ser mencionado em favor da opinião favorável, pois, em relação aos demais, o mencionado estudioso sustenta serem todos absolutamente fora de propósito.

Trata-se do fragmento de Ulpiano D. 6, 3, 2, 1, onde são enumeradas as iustae causae de ação Publiciana e também a emptio-venditio bonae fidei e o dote, adiciona: "Item si res ex causa iudicati sit tradita”.

O autor admite ser fácil compreender que esse texto se referia à solutio da causa iudicata em uma ação pessoal.

A solutio foi isolada e somente mais tarde estabeleceu-se sua existência, tornando-se o último dos títulos nominados a conquistar a sua autonomia.

Além disso, tradere, traditio são termos usados pelos jurisconsultos romanos para solvere, solutio.

A questão acerca do juramento e do julgado pode, ainda, ser analisada sobre outro aspecto.

Indaga P. BONFANTE ${ }^{222}$, se pela parte que reconhece o título putativo e deposita em substância toda a função justificativa do usucapião na boa-fé, para o direito justinianeu, podem os dois atos simultaneamente valerem como iusta causa erroris?

A. BRINZ, opondo-se a B. WINDSCHEID, sustenta que dois atos não podem, concomitantemente, serem considerados iusta causa erroris.

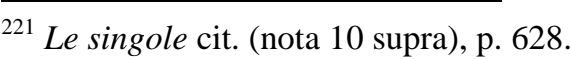


Por outro turno, observa P. BonfANTE ${ }^{223}$ que se C. ApPLETON ${ }^{224}$ declara que a sentença é título eficaz, isso porque ele compreende a iusta causa usucapionis como a própria iusta causa erroris.

P. BonfANTE ${ }^{225}$, por outro lado, nega ao juramento e à sentença até mesmo essa virtude.

Argumenta o autor que o juramento não é iusta causa usucapionis, ele estabelece apenas uma relação obrigatória entre aquele que o recebe e aquele que o prestou, logo, não terá valor em juízo diante de um terceiro a quem não foi deferido o testamento.

O único valor que produzirá diante desse terceiro é aquele de afirmação solene da própria parte, que é justamente a de provar a integridade e o comportamento honesto.

Em relação à sentença, o autor propõe o mesmo raciocínio.

Se para o novo juiz, o juramento não é mais que umaafirmação solene da parte, a sentença precedente é apenas uma opinião autoritária, porém falível, de uma outra pessoa.

Não importa que essa outra pessoa, em outra ocasião, seja o juiz que decidiu sobre o direito do possuidor, uma vez que a velha sentença não obriga o novo juiz e também não vale como iusta causa para o usucapião.

O novo juiz deve analisar o pedido independentemente das causas que possam ter induzido em erro o possuidor em relação ao seu próprio direito e, a partir daí, caberá ao possuidor comprovar a sua boa-fé.

Assevera P. BONFANTE ${ }^{226}$ que velhos juramentos e velhos julgados terão valor de presunção moral indireta, que não eximirá o juiz da função de examinar a prova da verdade e da honestidade do possuidor.

A sentença diante de terceiros, não tem como finalidade justificar a posse do agente erga omnes e colocá-lo na condição de usucapir, ainda que possa eliminar a dispusta e produzir o direito como res iudicata.

\footnotetext{
${ }^{222}$ Le singole cit. (nota 10 supra), p. 629.

${ }^{223}$ Le singole cit. (nota 10 supra), p. 629.

${ }^{224}$ Publicienne, I, p. 330, cit. por P. BONFANTE, Le singole cit. (nota 10 supra), p. 629.

${ }^{225}$ Le singole cit. (nota 10 supra), p. 629.

${ }^{226}$ Le singole cit. (nota 10 supra), p. 629.
} 


\section{Título pro suo}

O título pro suo não indica nenhuma iusta causa específica.

Pro suo possidere, define P. BONFANTE ${ }^{227}$, significa que se possuiu com base em uma iusta causa e se pode, portanto, usucapir, se já não se é o proprietário.

É, em resumo, uma denominação genérica, a qual expressa que o possuidor tem a propriedade ou uma posse apta ao usucapião.

Entretanto, a dificuldade da compreensão dessa modalidade de iusta causa pela doutrina tem gerado uma série de debates acerca da sua natureza.

Para J. VENDRAND-VOYER ${ }^{228}$, a posse pro suo é uma reunião heterogênea de causas diversas, a qual pode ser aplicada em hipóteses diferentes, por exemplo, quando um título é nulo, inexistente ou não responde às condições exigidas para a aquisição da propriedade.

Segundo L. VACCA ${ }^{229}$, alguns juristas sugeriram a existência de possessio ex iusta causa em determinados textos inseridos na categoria pro suo, todavia, estes escritores não compreenderam o real significado atribuído pelas fontes em relação ao possidere pro suo.

Para a autora, o caso mais evidente em que a possessio pro suo opõe-se à possessio aliena nomine seria nas situações de possessio das coisas que se adquire como próprias, i.e, a título originário, como na situação narrada por Paulo em D. 41, 10, 2 :

"Est species possessionis, quae vocatur pro suo, hoc enim modo possidemus omnia, quae mari terra caelo capimus aut quae alluvione fluminum nostra fiunt, item quae ex rebus alieno nomine possessis nata possidemus, veluti partum hereditariae aut emptae ancillae, pro nostro possidemus: similiter fructus rei emptae aut donatae aut quae in hereditate inventa est".
Há uma espécie de posse que se chama pro suo. Desse modo, possuímos todo o que capturamos no mar, terra e ar, ou o que se faz nosso pelo aluvião dos rios; assim também os produtos que possuímos de coisas que possuímos por <outra> causa, como o filho de uma escrava hereditária ou comprada, que possuímos como nosso; igualmente o fruto de uma coisa comprada, doada ou que se encontrava entre as coisa da herança.

\footnotetext{
${ }^{227}$ Le singole cit. (nota 10 supra), p. 631.

${ }^{228}$ Possessio Pro Suo in Sodalitas - Scritti in onore di Antonio Guarino, 3, Jovene, Napoli, 1984, p. 1.404.

229 “Iusta causa" e "bona fides" cit. (nt. 12 supra), p. 1.959.
} 
Por outro turno, P. BONFANTE não menciona este fragmento citado por L. VACCA.

Provavelmente, porque a primeira parte do texto refere-se a ocupação de coisas.

A ocupação não é uma iusta causa de usucapião e, quanto à parte final do fragmento que se refere ao caso da escravas, o mesmo Paulo narra situação semelhante no fragmento D. 41, 3, 4, 5, enfrentado por P. BONFANTE mais adiante.

Para P. BONFANTE ${ }^{230}$, a melhor definição que é trazida pelos textos romanos sobre a definição da possesso pro suo é o fragmento de Ulpiano, D. 41, 10, 1:

"Pro suo possessio talis est. Cum dominium nobis adquiri putamus, et ex ea causa possidemus, ex que adquiritur, et praeterea pro suo: ut puta ex causa emptionis et pro emptore et pro suo possideo, item donata, vel legata, vel pro donato, vel pro legato, etiam pro suo possideo. Sed si res mihi ex causa iusta, puta emptionis, tradita sit et usucapiam, incipio quidem et ante usucapionem, dubitatur: et Mauricianus dicitur existimasse non desinere".
A posse pro suo é assim: quando acreditamos que uma coisa é nossa, possuímos pela causa que seja e ademais pro suo; por exemplo, se possuo por causa de uma compra, possuo pro emptore; também possuo pro suo as coisas que me foram doadas, legadas, ao mesmo tempo que pro donato ou pro legato. 1. Mas se me foi entegue uma coisa por uma iusta causa como a compra e a estou usucapindo, começo a possuir pro suo desde antes de terminar o usucapião, mas é duvidoso se eu deixarei de possuir por causa da compra, uma vez que tenha terminado o usucapião e se diz que Mauriciano considerava que não se deixava de possuir por esta causa.

Essa definição pode ser interpretada conjuntamente ao texto de Paulo, D. 41, 2, 3, 4:

"Ex plurimis causis possidere eandem rem possumus, ut quidam putant ${ }^{231}$ et eum, qui usuceperit et pro emptore, et pro suo
Podemos possuir uma mesma coisa por diversas causas ao mesmo tempo, como acreditam alguns que aquele que usucapiu

\footnotetext{
${ }^{230}$ Le singole cit. (nota 10 supra), p. 631.

${ }^{231}$ P. BONFANTE sugere a substituição de putant por putent, para melhor sentido na frase - Le singole cit. (nota 10 supra), p. 632.
} 
possidere: sic enim et si ei, qui pro emptore possidebat, heres sim, eandem rem et pro emptore et pro herede possideo: nec enim sicut dominium non potest nisi ex una causa contingere, ita et possidere ex una dumtaxat causa possumua". possui pro emptore e como possuidor pro suo; e assim também, se sou herdeiro daquele que possuía pro emptore e pro herede, pois assim como a propriedade somente se pode ter por uma única causa, também a posse deve-se ter como uma única causa.

Talvez a principal divergência entre o pensamento de P. BONFANTE e de L. VACCA é que, enquanto para o autor mais antigo a posse pro suo é uma legítima causa de usucapião, para a escritora, possuir pro suo indica tão somente um tipo de posse e não uma iusta causa.

Para a citada autora, possuir pro suo significa adquirir e possuir algo, tão somente com base em uma relação entre sujeito e a coisa, ou seja, uma situação de fato que acarrete uma aquisição direta, não advinda de uma relação anterior.

Para L. VACCA ${ }^{232}$, este é o entendimento que está com consonância com o fragmento D, 41, 10, 1 pr. de Ulpiano.

Acrescenta a citada romanista, que o texto de Ulpiano apresenta a mesma acepção de possessio pro suo em relação àquela expressada por Nerácio (D. 41, 10, 5), isto é, possui pro suo aquele que possui a coisa com a convicção de ter adquirido a propriedade dela.

Logo, aquele que adquire em boa-fé ex causa emptionis, também possui em boa-fé e justamente por estar possuindo com base na boa-fé, possui também pro suo.

Por esta razão defende que a posse pro suo é apenas de um tipo de posse, onde, havendo a convicção de ser proprietário, devido à boa fé, pode também conduzir à usucapio, mas não pode, de modo algum, ser compreendida como uma iusta causa usucapionis.

Já P. BONFANTE ${ }^{233}$ defende que essa posse pro suo é sempre presumida ex iusta causa, e coloca-se em antítese a todas aquelas posses que, por qualquer razão, não sejam aptas ao usucapião, como se vê das seguintes hipóteses:

Por exemplo, Pompônio, em D. 41, 3, 32 pr., cita a posse pro suo em oposição à possessio pro furtivo, como ele chama a posse do ladrão, i.e, uma possessio pro possessore qualificada. 
Já Paulo, D. 41, 3, 13 pr, em teor semelhante à posição de Gaio, em D. 6, 2, 13, 1, menciona essa posse em oposição a uma possessio pro alieno, mesmo ela iusta, não apta ao usucapião, como a posse do credor pignoratício, ou apta, porém, mas em forma anormal e em favor de outro, como a posse do mandatário.

O gênero pro suo é usado também por Ulpiano, em D. 29, 2, 20 ,1, em relação àquele que não é herdeiro, mas acredita que a coisa seja sua (quod putativ sua).

Gaio, em D. 41, 3, 5, opõe a possessio pro suo à aquela espécie anômala de posse ad usucapionem, mas sem substrato verdadeiro de iusta causa, a qual constitui a lucrativa usucapio.

Assim, sustenta P. BONFANTE ${ }^{234}$ que sendo o título pro suo uma fórmula abstrata de qualquer título específico, com ele se acumula, por exemplo, os dois primeiros textos citados de Paulo e de Ulpiano.

Isso produz reflexo também no título pro possessore, o mais contrastante de todos, o qual substitui a qualquer título, onde por falta de boa-fé na posse ele não teria a virtude de conferir a possessio pro suo, como se verifica em D. 5, 3, 13, 1:

"Omnibus etiam titulis hic pro possessore haeret et quase iniunctus est. Denique et pro emptore titulo haeret: nam si a furioso emero sciens, pro possessore possideo. Item in titulo pro donato quaeritur, na quis pro possessore possideat, ut puta uxor vel maritus: et placet nobis Iuliani sententia, pro possessore possidere eum, et ideo petitione hereditatis tenebitur. Item pro dote titulus recipit pro possessore possessionem, ut puta si a minore duodecim annis nupta mihi quasi dotem sciens accepi; et si legatum mihi solutum est ex falsa causa scienti, utique pro possessore possidebo".
A todos os títulos acompanha e segue unido a ele $\mathrm{o}<$ título > pro possessore. Mesmo seguindo aderido ao título pro emptore, porque se, cientemente, eu tivesse comprado alguma de coisa de um louco, possuo pro possessore. Também quanto ao título pro donato se pergunta se alguém possuirá às vezes pro possessore, por exemplo, nos casos das doações da mulher ao marido; e seguimos a opinião de Juliano, de que se possui como simples possuidor e, por consequência, pode ser demandado pela petição de herança. Também o título pro dote proporciona às vezes a posse pro possessore; por exemplo, se recebi, cientemente, de uma menor de doze

\footnotetext{
232 “Iusta causa” e "bona fides” cit. (nt. 12 supra), p. 1.960.

${ }^{233}$ Le singole cit. (nota 10 supra), p. 632.

${ }^{234}$ Le singole cit. (nota 10 supra), p. 633.
} 
anos, que se casou comigo, alguma coisa como dote; e se eu recebi, cientemente, um legado em virtude de uma falsa causa, possuirei certamente pro possessore.

Ademais, sustenta P. BONFANTE ${ }^{235}$ que a denominação pro suo é um excelente refúgio para se ter significado de posse ad usucapionem, quando a existência de uma iusta causa usucapionis não é duvidosa, mas o caráter ambíguo dela a deixa incerta a modalidade.

Cita como exemplo um caso de Papiniano (Frag. Vat. 260), exemplificando o usucapião que cumpre o filho emancipado sobre objetos do pecúlio não retirados do pai.

No fragmento sucessivo (Frag. Vat. 261), Papiniano estabelece que não sendo retirado o pecúlio do escravo manumitido, significa que foi doado, o que faz com que o escravo possua ex iusta causa.

Em síntese, essa denominação apresenta-se como a saída viável para aquelas situações onde existe uma relação real de não lesão a outro na tomada da posse, logo, uma iusta causa, porém, as denominações específicas faltam absolutamente para classificá-las.

P. Bonfante ${ }^{236}$ quando trata do título pro dote menciona que Próculo e Juliano, Paulo e Ulpiano chamam de pro suo o usucapião das coisas oferecidas em dote, quando isso acontece antes do matrimônio.

Semelhantemente, identifica que Pompônio, em D. 41, 10, 4, 1, decide que procedet pro suo o usucapião onde o filho adquire as res alienae.

Assevera o autor que a denominação pro suo sempre aparece nos textos para designar as causas originárias de aquisição ou de usucapião, o que se torna evidente que a iusta causa não é um negócio, mas uma relação.

Essa relação pode até ser implícita em um negócio, mas pode resultar também de um fato ou do estado das coisas, especialmente, quando se verifica na consciência comum a inexistência de lesão na tomada da posse.

O criador dos títulos autônomos e especiais, Paulo, declara como simplesmente pro suo a posse das res nullius que são ocupadas do inimigo, das coisas novas obtidas mediante

\footnotetext{
${ }^{235}$ Le singole cit. (nota 10 supra), p. 633-634.

${ }^{236}$ Le singole cit. (nota 10 supra), p. 634.
} 
especificação, das acessões e, também, das partes e dos frutos.

P. BONFANTE ${ }^{237}$ vê com certa insegurança a inserção da categoria "partes e frutos" na designação pro suo.

Aduz P. Bonfante ${ }^{238}$ que a mutabilidade da coisa frutífera, mesmo destacada do objeto principal, faz com que ela apareça ora como parte, ora como coisa nova e distinta, desse modo, pode ser classificada como causa justificativa de aquisição a mesma iusta causa de coisa produtiva.

Além disso, a jurisprudência romana oscila acerca da matéria da partes. Juliano e Ulpiano entendem que as partes da escrava decorrem da mesma causa da mãe ${ }^{239}$.

Para o autor, a admissão de um novo título relativamente aos produtos pode ter feito com que o entendimento de Paulo se tornasse isolado.

Observa, ainda, que Juliano elaborou um argumento mais extenso que leva à mesma conclusão lógica.

A hipótese refere-se à venda de uma vaca e que vem evicto o vitelo nascido depois da compra e venda.

Explica o romanista que nesse caso não se pode agir pela evicção, já que não é dada evicta a própria coisa, a propriedade dela e nem o usufruto, isto é, em substância uma parte do direito de propriedade.

Por essa razão, quando se diz que o vitelo é fruto da vaca, tem-se a intenção de dizer que significa o produto material, não o direito de usufruto.

Para o usucapião essa divergência é relevante, pois, observa P. BONFANTE ${ }^{240}$ que se o possuidor detém em boa-fé a mãe, mas sem justo título, não poderia usucapir nem o parto, uma vez que o título do produto deve ser o mesmo da coisa produtiva.

Os defensores do título verdadeiro tinham que decidir dessa modo.

Explica o autor que talvez seja por isso que Paulo foi induzido a estabelecer que o produto se possui por um título novo, não pro emptore vel pro donato, mas pro suo.

Por essa razão, adverte o romanista, surgiu na ideia de muitos doutrinados a falácia de

\footnotetext{
${ }^{237}$ Le singole cit. (nota 10 supra), p. 635.

${ }^{238}$ Le singole cit. (nota 10 supra), p. 635-636.

${ }^{239}$ Os fragmentos de Juliano são D. 41, 3, 33, 3, D. 41, 4, 9 e 10 e de Ulpiano, D. 6, 2, 11, 4.

${ }^{240}$ Le singole cit. (nota 10 supra), p. 636.
} 
que esse uso da expressão pro suo designa o título putativo.

Acrescenta, ademais, que somente no texto de Próculo (D. 23, 6, 67) foi citado que se o título não é imaginário, ele é ao menos ineficaz.

Esclarece P. Bonfante ${ }^{241}$ que Próculo teria denominado o título dessa forma, não porque o título é putativo, mas porque não saberia outra forma fazê-lo.

Do mesmo modo, o autor não concorda com A. PERNICE quando diz que o texto teria sido interpolado.

Por outro turno, Juliano, Paulo e Ulpiano são forçados a chamá-lo pro suo, mesmo quando ele é bem verdadeiro, e Próculo, adverte o autor, não se achava em seu tempo em melhores condições quanto à terminologia jurídica.

Os fragmentos D. 41, 10, 3, D. 41, 10, 4 pr., D. 41, 10, 4, 2, de Pompônio, a lei D. 41, 3, 27 de Ulpiano e o texto D. 41, 10, 5, de Nerácio são outros textos dos quais a doutrina parece deduzir o caráter putativo do título pro suo.

Quanto aos textos de Pompônio (exceto o D. 41, 10, 4 pr.), como P. Bonfante ${ }^{242}$ já teria explanado, não interessa se o título é verdadeiro ou putativo.

No caso de D. 41, 10, 3 existe um título verdadeiro na solutio.

Em relação ao fragmento D. 41, 10, 4, 2, onde se lê "placet a legatario usucapi, quia pro suo possidet" o autor conclui que se Pompônio se referia a um legado per damnationem, ele teria chamado esta posse pro soluto, evidentemente, se a possessio pro soluto fosse definida autonomamente ao seu tempo, mas não era.

Por esse motivo, o jurisconsulto usa da qualificação genérica pro suo para declarar que ali existe uma posse suficientemente justificada e apta a conduzir ao usucapião.

Subsiste, portanto, a análise do texto D. 41, 10, 4, onde, na opinião do autor, Pompônio enuncia uma regra que é verdadeira, mas aplica-a de forma errônea:

"Si ancillam furtivam emiste fide bona, ex ea natum et apud te conceptum est ita possedisti, ut intra constitutum usucapioni tempus
Se tivesse comprado de boa-fé uma escrava alheia e possuído o que ela concebeu estando em teu poder, de sorte que tenha a ficado

\footnotetext{
${ }^{241}$ Le singole cit. (nota 10 supra), p. 637.

${ }^{242}$ Le singole cit. (nota 10 supra), p. 637.
} 
congnosceres matrem eius furtivam esse, Trebatius omni modo, quod ita possessum esset, usucaptum esse, ego sic puto distinguendum, ut, si nescieris intra statutum tempus, cuius id mancipium esset, aut si scieris neque potueris certiorem dominum facere, aut si potueris quoque et feceris certiorem, usucaperes: sin vero, cum scires et posses, non feceris certiorem, contra esse: tum enim clam possedisse videberis, neque idem et pro suo et clam possidere potest. 1 . Si pater cum filiis bona quae habebat partius sit et ex ea causa post mortem patris ea teneant, quod inter eos conveniret, ut ea divisio rata esset: usucapio his procedet pro suo in his rebus, quae alienae in bonis patris inveniuntur. 2. Quod legatum non sit, ab herede tamen perperam traditum sit, placet a legatario usucapi, quia pro possuo possidet”. sabendo dentro do prazo indicado para o usucapião de que a mãe havia sido furtada, $<$ diz> Trebácio que se usucape em todo caso aquele que assim possuiu. Eu creio que se deve distinguir: se dentro do tempo legalmente indicado <para o usucapião> não tenha ouvido falar <de que a escrava foi furtada $>$ ou tenha ouvido falar, mas não pode averiguar quem é o dono, ou pôde e o averiguou, poderá usucapir, mas se o sabias, e podendo, não o averiguou, não poderás, pois então se considerará que possuiu clandestinamente, e não pode uma pessoa possuir uma coisa ao mesmo tempo pro suo e clandestinamente. 1. Se um pai repartiu com seus filhos os bens que ele tinha e, depois de morrer o pai, eles o reteram pela razão de que estavam convencidos em se manter aquela divisão, procede em seu favor o usucapiao pro suo naqueles bens que, sendo alheios, se encontravam entre os do patrimônio paterno. 2. Se não é legado, por herança indevidamente se fez a tradição, satisfaz o legatário usucapilo, porque o possuiu pro suo.

Esclarece P. BONFANTE ${ }^{243}$ que este princípio geral da possessio ex iusta causa é muito mal interpretado, restringindo-o a um sentido particular da possessio pro suo.

O princípio é correto, pois na iusta possessio e na possessio bonae fidei é relevante o momento em que se tomou a posse.

Ademais, o próprio autor em relação ao segundo parágrafo, quando cuidou do título pro legato, já havia se posicionado no sentido de que o mesmo é uma clara referência à admissão do título putativo pelas fontes romanas.

Todavia, este pensamento não é acompanhado por L. VACCA.

\footnotetext{
${ }^{243}$ Le singole cit. (nota 10 supra), p. 638.
} 
Diz a autora, que Pompônio é que outro jurista a quem se atribui tradicionalmente afirmação do título putativo ${ }^{244}$.

Entretanto, para citada romanista, o texto de Pompônio é excessivamente genérico e refere-se à possibilidade de se admitir uma possessio pro suo apta a conduzir à usucapio somente com base na boa-fé.

Esse fragmento de Pompônio trafegaria no mesmo sentido de Nerácio, atribuindo relevância de erro tolerável "che quindi come tale non esclude la possessio pro suo, e di conseguenza l'usucapione, ai casi in cui non vi sai negligenza da parte del possessore, ma piutosto errore e inatività altrui ${ }^{245}$,".

A primeira fattispecie trata do caso daquele que possui um filho nascido de uma escrava, cuja origem de furto era ignorada, todavia, que se tornou conhecida antes que se cumprisse o usucapião.

Nesta hipótese, segundo Trebácio, considerando que havia boa-fé inicial, será admitida a usucapio.

Da hipótese analisada, conclui L. VACCA ${ }^{246}$ que o possuidor exercendo uma posse nec vi, nec clam, nec precario, estará apto a usucapir pro suo, entretanto, se ele tiver meios para identificar quem é o verdadeiro proprietário, será excluída a possessio pro suo, pois passará a posse a ser clam.

Para a autora, o que Pompônio exige do possuidor, além da boa-fé, é uma espécie de zelo, para que esta possessio pro suo seja apta a conduzir ao usucapião.

Por tal razão, o erro alheio também não exclui a possessio pro suo.

No primeiro parágrafo do fragmento ele trata do erro de um paterfamilias que divide bens entre os filhos, sendo alguns desses bens pertencentes a terceiros, mas usucape-se pro suo porque a posse era de boa-fé e, concomitantemente, o erro era ignorado.

A mesma solução se aplicaria também no caso em que um legatário, possuindo pro suo, venha a usucapir aquilo que tenha sido transmitido por erro e que não foi efetivamente legado.

Todavia, o texto que melhor representa a ideia do título putativo e sobre o qual se construiu grande parte das teorias é o fragmento de Nerácio, D. 41, 10, 5:

${ }^{244}$ L. VACCA, “Iusta causa" e "bona fides” cit. (nt. 12 supra), p. 1.965. 
"Usucapio rerum, etiam ex aliis causis concessa interim, propter ea, quae nostra existimantes possideremus, constituta est, ut aliquis litium finis esset. 1. Sed id, quod quis, cum suum esse existimaret, possederit, usucapiet, etiamsi falsa fuerit eius existimatio, quod tamen ita interpretandum est, ut probabilis error possidentis usucapioni non obstet, veluti si ob id aliquid possideam, quod servum meum aut eius, cuius in locum hereditario iure successi, emisse id falso existimem, quia in alieni facti ignorantia tolerabilis error est".
O usucapião das coisas, às vezes também concedido por outras causas, para que os litígios tenham algum fim, mas aquilo de que alguém, julgando ser seu, se tiver apossado, < esse mesmo alguém > usucapirá o que, todavia, há de ser interpretado de modo que o erro provável do possuidor não obste ao usucapião, como, por exemplo, se eu possuir alguma coisa em razão de falsamente acreditar que um escravo meu, ou de alguém em cujo lugar sucedi por direito hereditário, o tivesse comprado, o erro na ignorância de fato alheio é tolerável.

Nerácio não usa a expressão pro suo, mas, para P. BONFANTE ${ }^{247}$, parece que tal possessio se contrapõe a uma similar possessio ex aliis causis.

Entretanto, o autor adverte que a interpolação do inciso "etiam ex aliis causis concessa interim" é evidente ${ }^{248}$.

Acentua o autor que a enunciação do título putativo, baseado na falsa existimatio apoiada no probabilis error do possuidor, teria sido feita por Nerácio somente mais tarde com uma aplicação especial daquele princípio geral.

Para L. VACCA, em contraposição ao entendimento de P. BONFANTE, este fragmento, que é tradicionalmente adotado pela doutrina como de uma hipótese de adoção do título putativo é "forse uno dei passi di interpretazione piú controversa in tutta la dottrina romanistica",249.

Segundo a autora, o fragmento atém-se mais ao problema da boa-fé do que ao título.

A análise mais adequada acerca do real significado do texto de Nerácio, defende a

\footnotetext{
${ }^{245}$ L. VACCA, “Iusta causa” e "bona fides” cit. (nt. 12 supra), p. 1.965.

246 “Iusta causa” e "bona fides" cit. (nt. 12 supra), p. 1.966.

${ }^{247}$ Le singole cit. (nota 10 supra), p. 639-640.

${ }^{248}$ Assim também pensava CuJÁCIO, Ad. Tit. Pro suo, L.5; Opera, I, p. 1150, e T. Mommsen corrige interim por interdum e interrompe a enunciação do princípio; e o princípio é apenas uma justificação geral do instituto da usucapio "Ea quae nostra existimantes possideremus", não são necessariamente as coisas que se possui com base em um título putativo, mas também aquelas que se possui com base em um título verdadeiro. - P. BONFANTE, Le singole cit. (nota 10 supra), p. 640-641.

249 “Iusta causa" e "bona fides" cit. (nt. 12 supra), p. 1.960.
} 
autora, foi a desenvolvida por T. MAYER-MALY, que teria interpretado adequadamente o texto quando sugeriu na primeira parte uma referência histórica à primitiva usucapio em favor daquele que possuía a coisa como sua.

O estudioso citado pela autora teria se referido ao usus decenviral de forma coligada à mancipatio, o que salvaguardaria o adquirente de boa-fé a non domino.

$\mathrm{Na}$ segunda parte do texto, o autor teria feito uma interpretação mais recente do elemento da existimatio do possuidor, onde se resume o conceito de boa-fé e na qual é recompreendida, segundo Nerácio, à hipótese que alguém, errando sobre fato alheio considerar possuir algo como proprietário.

Logo, T. MAYER-MALY teria interpretado o texto não como afirmação genérica do título putativo, mas sim de maneira mais restritiva em relação à doutrina tradicional, pois examinou a questão de maneira vinculada à teoria do tolerabilis error com a finalidade da boa-fé ${ }^{250}$.

A autora sustenta que todo o andamento do texto de Nerácio "mostra lo sforzo di individuare, sia pura dando per pressuposta la regola generale che l'usucapio procede ove vi sia uma iusta causa, la rilevanza di uma falsa existimatio del possessore, tipizzando i casi in cui essa non si debba considerare preclusiva dell'usucapio ${ }^{251}$ ".

Os princípios que se invocam, acrescenta a romanista em comento, são aqueles gerais em matéria de erro, onde o erro de fato não venha a acarretar prejuízo a quem nele tiver incorrido e que, ao mesmo tempo, não esteja eivado de negligência inescusável.

A observação que faz L. VACCA é que a firmeza desta colocação de T. MAYER-MALY levaria-nos necessariamente à conclusão do quanto é falsa qualquer perspectiva em que se queira reconduzir cada solução a um único dogma conceitual, qual seja: a necessidade de uma iusta causa, se não efetiva, pelo menos putativa.

Por esta razão, ressalta a mesma autora, ao considerar a máxima de que a usucapio poderia se proceder somente embasada em uma iusta causa, isto não exclui que a interpretatio possa eventualmente aceitar a usucapio mesmo que independentemente da iusta causa.

Destarte, a dificuldade para o jurista moderno está em compreender a harmonia da

\footnotetext{
${ }^{250}$ Das Putativtitelproblem cit. (nota 13 supra), p. 55, cit. por L. VACCA, “Iusta causa" e "bona fides" cit. (nt. 12 supra), p. 1.961.

${ }^{251}$ L. VACCA, “Iusta causa” e “bona fides" cit. (nt. 12 supra), p. 1.961.
} 
pluralidade de soluções possíveis que nos teria sido deixada pelos romanos.

Provavelmente dificuldade teria sido causada pelos compiladores justinianeus através da frequente amputação de trechos das controvérsias ou, ainda, através de inserções de diversos fragmentos em um contexto estranho ao original.

Logo, acabou-se reduzindo a uma unidade, aquilo que na verdade parecia ser uma diversidade ${ }^{252}$.

Há um fragmento de Ulpiano, D. 41, 3, 27, que P. BonfANTE ${ }^{253}$ alega que o inciso "pro suo usucapere eum posse" trata-se, provavelmente, de um glossema, pois foi destacado gramaticalmente do resto do período.

Todavia, considerando que o inciso seja verdadeiro, o mencionado autor sinaliza que não há dificuldade de interpretação.

Esgotando a análise dos fragmentos do Digesto referentes ao título pro suo, L. VACCA conclui que a denominação pro suo não indica um título de usucapio, do mesmo modo, em nenhum caso a posse pro suo é considerada uma posse ex iusta causa, pois situações analisadas são relativas à boa-fé (compreendida pela convicção de ser o proprietário ou corresponder-se a tal), fundamentada por um erro decorrente da negligência de terceiros, portanto, escusável.

A autora reconstrói o pensamento de Nerácio e Pompônio do seguinte modo: excluemse, primeiramente, os casos em que a usucapio se cumpre sob a base de uma possessio ex iusta causa.

Consequentemente, as demais hipóteses, verifica-se as situações onde há juridicamente a possibilidade do reconhecimento da propriedade pelo fato da posse advir de um erro escusável, i.e, que não seja arbitrária ou decorrente de dolo ou culpa.

Por conseguinte, extrai-se então a certeza de que essa convicção de ser o dominus conduz à ideia de possessio pro suo, e não de uma iusta causa usucapionis.

Portanto, para L. VACCA ${ }^{254}$, todas essas situações observadas nos fragmentos não guardam qualquer relação com a admissibilidade ou não do título putativo.

\footnotetext{
${ }^{252}$ L. VACCA, “Iusta causa”e "bona fides" cit. (nt. 12 supra), p. 1.963.

${ }^{253}$ Le singole cit. (nota 10 supra), p. 640-641.

${ }^{254}$ Iusta causa" e "bona fides" cit. (nt. 11 supra), p. 1.967.
} 


\section{O alegado usucapião pro herede do herdeiro verdadeiro.}

Sustenta P. BonfANTE ${ }^{255}$ que este é um título dúplice de usucapião e, em uma de suas formas, o mais obscuro e ao mesmo tempo mais elaborado de todos os títulos.

Com exceção da lucrativa pro herede usucapio, cuja existência antiga teria sido detectada pela primeira vez nas Instituições de Gaio, o título pro herede possui sua própria literatura no direito justinianeu.

Para o autor, a dificuldade em relação ao título pro herede decorre de sua origem equivocada, desse modo, o melhor guia para a compreensão do instituto e para a exegese dos textos será conceito geral da iusta causa.

Dizer que o título pro herede possui caráter dúplice, significa que ele se aplica ao usucapião de coisas que falsamente se acreditam hereditárias em favor do herdeiro verdadeiro, o qual será analisado primeiramente e, de outro modo, ele pode se aplicar ao usucapião de coisas verdadeiramente hereditárias em favor do herdeiro aparente.

O autor observa que a hereditas não tem esta natureza, tomando por base o conceito da iusta causa usucapionis, em abstrato.

Isso porque a herança seria apenas uma causa e, assim como o legado, um modo de aquisição da propriedade.

Logo, ela não seria causa de aquisição mais do que aquelas deferidas pelos direitos de garantia, de usufruto, ou ainda para as relações obrigatórias de depósito, de locação e similares.

O que pretende autor é demonstrar que essa particularidade é que conduziria à compreensão de que a herança é a causa que justifica a aquisição dos direitos que tinha o falecido.

Assim, se o falecido tinha a propriedade, será justificada a aquisição da propriedade, entretanto, se o falecido era usufrutuário, locatário ou comodatário, será justificado tão somente os direitos decorrentes dessas relações.

${ }^{255}$ Le singole cit. (nota 10 supra), p. 641-642. 
Desse modo, compreende-se que não haverá alteração na iusta causa, a hipótese do herdeiro imaginar ter se tornado proprietário dos objetos que o falecido possuía a título de deposito ou comodato.

Sustenta P. BONFANTE ${ }^{256}$ que a única evidência que se extrai dessa situação é que ele estaria em boa-fé, e justamente por conta dissso, não se pode dizer que se baseia sobre um erro escusável, pois ele deveria saber que, tornando-se herdeiro, não faria outra coisa senão suceder naqueles direitos que o falecido tinha sobre a coisa.

Para o autor, a espécie é muito semelhante ao caso daquele que recebe os objetos em depósito e acredita erroneamente que é o proprietário dos mesmos.

Nesse caso, não existe uma iusta causa, porque o depositante não quis renunciar à coisa em favor do depositário.

Em comparação com esse exemplo, o herdeiro, como sucessor, está precisamente na posição de depositário, então ele pode acreditar que é proprietário em perfeita boa-fé, mas na verdade se enquadra em uma relação de depósito.

Assevera P. BonfANTE ${ }^{257}$ que ainda mais grave seria a hipótese se o falecido não possuísse a coisa por título algum.

Nesse caso, se verificaria absoluta ausência de iusta causa.

Essa é a hipótese trazida pelos textos.

Os jurisconsultos defensores do título verdadeiro nada mencionam sobre este usucapião.

Genericamente, ela aparece em apenas dois rescritos de Diocleciano, mas em ambos nega-se o cabimento da usucapio e da longi temporis praescriptio, precisamente, porque na espécie não se tem um título.

C. 7, 29, 4:

"Usucapio non praecedente vero titulo procedure non potest: Diutina possessio iure tantum sucessionis sine iusto titulo obtenta
Não procedendo <como> verdadeiro <o> título, não pode ser procedente o usucapião; nem pode aproveitar àquele que a tem, e nem

\footnotetext{
${ }^{256}$ Le singole cit. (nota 10 supra), p. 642-643.

${ }^{257}$ Le singole cit. (nota 10 supra), p. 643.
} 
prodesse ad praescriptionem ec obtentu velut ex hereditatem quod alienum fuit, domini intentio ullo longi temporis spatio absumitur".

\section{7, 33, 4:}

"Diutina possessio iure tantum sucessionis sine iusto titulo obtenta prodesse ad praescriptionem hac sola rationem non potest". a seu herdeiro, nem sob o pretexto, por exemplo, de ter por herança o que foi de outro, se ele retira do dono por qualquer espaço de tempo sua exigência.
A posse de muito tempo, obtida somente por direito de sucessão sem justo título não pode, por essa única razão, aproveitar para a prescrição".

Nos textos, observa-se a negação do usucapião tal modo que, embora houvesse quem o admitisse em hipóteses semelhantes, P. BONFANTE ${ }^{258}$ adverte que não deveria se chamar pro herede.

Acrescenta o autor que se a hereditas, o ius successionis não é iustus titulus, como parece confirmar os textos, não poderia ser agora, até mesmo porque se admite o título putativo.

Os defensores deste título deixam de lado a realidade da iusta causa, mas não lhe alteram a natureza.

A reconhecida inconsistência dos compiladores, aliada ao fato de não existir no Codex o título pro suo, faz com que o autor não entenda como extraordinário o fato do primeiro texto ter sido enquadrado no título pro herede.

Afirma P. BONFANTE ${ }^{259}$ que os jurisconsultos que se posicionavam favoravelmente ao título putativo, certamente se inclinariam a reconhecer o usucapião em uma situação como essas, mas, provavelmente, o fariam com base em um título especial onde o herdeiro supõe o falecimento ou na modalidade que geralmente usavam para esse caso, o título pro suo.

Sugere o autor que o melhor exemplo trazido pelas fontes é o texto fundamental de Nerácio (D. 41, 10, 5) sobre o título putativo, onde no exemplo de probabilis error o jurisconsulto afirma que "quod servum eius, cuius in locum hereditário iure sucessi, emisse id falso existimem"

${ }^{258}$ Le singole cit. (nota 10 supra), p. 644. 
E o texto de Pompônio D. 41, 5, 3, que embora não mencione que o usucapião procede pro herede, admite-o:

"Plerique putaverunt, si heres sim et putem rem aliquam ex hereditate esse quae non sit, posse me usucapere".
A maioria tem pensado que posso usucapir quando sou herdeiro e creio que pertence à herança alguma coisa que não é da herança.

Para P. BONFANTE ${ }^{260}$, Pompônio deveria admitir esse usucapião através de um título específico ou como fez Nerácio, por intermédio do título pro suo, mas os compiladores preferiram encaixá-lo no título pro herede.

Todavia, o que há de relevante é que a lei admite o usucapião.

Da leitura do texto de Pompônio, o autor sustenta que a interpretação mais provável caminha no sentido de que o texto refere-se a uma coisa que, embora o herdeiro a tenha encontrado entre os bens hereditários ou tenha confundido com eles por um erro, o falecido não tinha nem sequer a posse do mesmo.

A respeito das coisas que o falecido já possuía, observa o citado romanista que parece improvável que mesmo os defensores do título putativo não advertissem que o herdeiro somente pode herdar com relação ao falecido.

Acentua P. BONFANTE ${ }^{261}$ que existe uma flagrante contradição entre os fragmentos de Pompônio e os rescritos imperiais, considerando os conceitos acerca da iusta causa usucapionis e a iusta causa erroris, a menos que essa existência de textos contraditórios no Codex e no Digesto seja atribuída à distração dos compiladores.

Ademais, a usucapio pro herede do verdadeiro herdeiro não existiu no direito clássico e também não existe no direito justinianeu.

Para o autor, a designação pro herede corresponderia ao sentido genérico pro suo, mesmo que seja notável o esforço de indicar a posse do verdadeiro herdeiro.

\footnotetext{
${ }^{259}$ Le singole cit. (nota 10 supra), p. 644.

${ }^{260}$ Le singole cit. (nota 10 supra), p. 645.

${ }^{261}$ Le singole cit. (nota 10 supra), p. 645-646.
} 


\subsection{Origem e características especiais do usucapião pro herede do herdeiro} aparente no direito justinaneu

Em relação ao herdeiro aparente, o autor afirma que o resultado é semelhante àquele observado em relação ao herdeiro verdadeiro.

O prório nome já menciona a falta do título, logo, em abstrato, nesse caso sequer existe uma iusta causa.

A primeira observação que deve ser feita é a seguinte: herdeiro aparente (presumido) não é herdeiro.

Exemplifica P. BONFANTE ${ }^{262}$ que enquanto aqueles que receberam em doação ou compraram, são de qualquer modo donatário e comprador, ainda que tenham adquirido de quem não era verdadeiro proprietário, no caso do herdeiro aparente, alguém sempre será, em algum momento, induzido em erro.

Por exemplo, ele pode ser instituído em um testamento que mais tarde é revogado pelo testador.

Ora, se um testamento revogado é nulo de fato e de direito, esse herdeiro aparente, segundo o autor, poderia ter nesse caso uma iustissima erroris causa caso provasse a sua boafé, mas jamais uma iusta causa usucapionis.

A singularidade identificada por P. BONFANTE ${ }^{263}$ é que as fontes justinianeias reconectam algumas regras particulares próprias da antiga lucrativa pro herede usucapio nos textos onde falam de possessio e usucapio pro herede.

Para definir o que se deve levar dessa compreensão para o direito justinianeu, $P$. BONFANTE apresenta uma opinião baseada em L. ARNDTS ${ }^{264}$, a qual foi a opinião dominante por algum tempo.

Segundo L. ARNDTS, considerando que a antiga usucapio lucrativa pro herede também teria sido extinta por razões de equidade, o usucapião do herdeiro aparente não é essencialmente distinto dela.

\footnotetext{
${ }^{262}$ Le singole cit. (nota 10 supra), p. 646.

${ }^{263}$ Le singole cit. (nota 10 supra), p. 646.

${ }^{264}$ Ueber die “Usucapio pro herede”, Stuttgart, 1873, p. 125-142, cit. por P. BONFANTE, Le singole cit. (nota 10 supra), p. 646.
} 
Logo, o usucapião do herdeiro aparente era apenas uma aplicação da antiga lucrativa pro herede usucapio no direito prejustinianeu e, naturalmente, era sujeito às mesmas regras.

Assevera o romanista italiano que a usucapio lucrativa não teria sido destruída por Adriano, ele apenas estabeleceu a revogação, tornando-a inócua.

Do mesmo modo, também não teria sido desconstituída pela introdução do crime expilatae hereditatis, em relação a ela, poderia se exigir no máximo a boa-fé, ou seja, a crença de ser herdeiro para poder usucapir.

Este usucapião se constitui no novo direito uma forma excepcional, a qual teria sido trazida das fontes do direito clássico para as compilações justinianeias.

Afirma P. BONFANTE ${ }^{265}$ que nele o título será sempre putativo e muitas especialidades da lucrativa usucapio antiga voltam a reaparecer mesmo no direito justinianeu.

Alega, ainda, que L. ARNDTS não teria observado que o usucapião do herdeiro aparente era demasiado excepcional diante da exigência do justo título.

A opinião deste autor se restringiria ao momento da revogabilidade da lucrativa usucapio e, em discussão sobre este momento, estaria errada em parte.

Por conta desse eventual equívoco, L. ARNDTS tem sido vitoriosamente impugnado por A. ASCOLI ${ }^{266}$.

Esse romanista italian que pertenceu à mesma escola de P. BONFANTE teria voltado a estabelecer, conforme elucida o autor, uma clara separação entre o usucapião do herdeiro aparente, o qual é sempre um usucapião ordinário regrado pelas leis comuns e a usucapio lucrativa, cujas regras nunca foram aplicadas ao primeiro.

Para P. BonfAntE ${ }^{267}$, a crítica que A. AsCOLI desenvolve à opinião de L. ARNDTS é efetuada com reconhecida dialética, todavia, para P. BONFANTE, a doutrina de L. ARNDTS era inegavelmente melhor.

Assevera o autor que ela mais próxima da verdade, bem como, quando analisada por um aspecto mais abrangente, até mesmo a sua tese em relação à revogabilidade passa a ter mais sentido.

\footnotetext{
${ }^{265}$ Le singole cit. (nota 10 supra), p. 647.

${ }^{266}$ Studi sull'usucapione "pro herede" in Archivio giuridico, 38, 1887, pp. 317-359, cit. por P. BONFANTE, Le singole cit. (nota 10 supra), p. 647.

${ }^{267}$ Le singole cit. (nota 10 supra), p. 648.
} 
Em primeiro lugar, não é exato o pressuposto que no usucapião do herdeiro aparente se tem título verdadeiro, o que A. AsColi sustenta.

Salienta P. BonfANTE que A. AsCOLI se expressa de forma equivocada, pois ele afirma que o testamento é nulo por falta de forma, uma vez que a falsa opinião do herdeiro se basearia sobre um erro de direito, logo, compreende a iusta causa usucapionis e a iusta causa erroris como se fossem a mesma coisa.

Ele considera que a expressão usucapio pro herede não pode ter o mesmo significado que tem as expressões usucapio pro dote, pro emptore e similares.

O entendimento de A. ASCOLI seria no sentido de que ainda que estes institutos fossem aptos a indicar o título do usucapião, uma vez que se usucape por inexistência de um dote ou porque a coisa foi comprada, a denominação pro herede não indica a qualificação da posse, que o constituiria esse possuidor em boa-fée ${ }^{268}$.

Argumentos ainda mais graves são fornecidos pelo exame exegético dos textos, afirma P. BONFANTE ${ }^{269}$.

Para elucidar seu argumento, o autor examina cada uma das séries de princípios da antiga lucrativa pro herede usucapio separadamente, começando por aqueles já produzidos por L. ARNDTS e que, em seguida, foram rebatidos por A. AsCOLI.

\subsection{A lucrativa pro herede usucapio}

A lucrativa pro herede usucapio somente era possível, quando o herdeiro ainda não tivesse adquirido a posse das coisas hereditárias.

Afirma P. BONFANTE ${ }^{270}$ que esta regra teria sido determinada por Gaio como um requisito essencial da lucrativa usucapio.

Ademais, o mesmo princípio teria sido aplicado ao usucapião do herdeiro aparente em um texto justinianeu de Pompônio, em D. 41, 3, 29:

\footnotetext{
268 Studi cit. (nota 266 supra), p. 318.

${ }^{269}$ Le singole cit. (nota 10 supra), p. 648.

${ }^{270}$ Le singole cit. (nota 10 supra), p. 649.
} 
"Cum solus heres essem, existimarem autem te quoque pro parte heredem esse, res hereditárias pro parte tibi traditi. Propius est, ut usu eas capere non possis, quia nec pro herede usucapi, potest quod ab herede possessum est neque aliam ullam habes causam possidendi. Ita tamen hoc verum est, si non ex transactione id factum fuerit. Idem dicimus, si tu quoque existimes te heredem esse: nam hic quoque possessio veri heredis obstabit tibi".
Sendo eu herdeiro universal, acreditando que também você era herdeiro de uma parte e eu vou lhe entegrar em coisas hereditárias. É mais certo que não poderás usucapir essas coisas, porque não se pode usucapir pro herede o que já possui o herdeiro, nem tens outra causa de posse. Assim, com efeito, salvo se tivesse feito a entrega por causa de transação. O mesmo diremos no caso em que você acredita que é herdeiro, pois também então a posse do verdadeiro herdeiro impede que possuas < pro herede $>$.

Para o autor, o entendimento de A. Ascoli é que Pompônio se referia no último inciso (Idem dicimus, etc.) sempre à usucapio pro herede do possuidor de má-fé.

Isso seria compreendido através do seguinte exemplo citado por ele: mesmo se Tício estiver de boa-fé, ele não pode usucapir, porque na espécie não há um título, poderia, pelo menos, tirar proveito da usucapio lucrativa pro herede? Não, porque de todo modo a sua posse é posterior à do verdadeiro herdeiro ${ }^{271}$.

P. BONFANTE ${ }^{272}$ afirma que a interpretação de A. AsCOLI é engenhosa, especialmente para um texto que parece em aberta contradição com a tese desse mesmo autor.

Isso porque, quando Pompônio se refere à usucapio pro herede ele encontra um obstáculo à sua realização na possessio veri heredis, seja de boa ou de má-fé a posse.

Portanto, para o autor, A. AsCOLI deveria concordar que o texto pode ser compreendido com mais naturalidade, no sentido proposto por L. ARNDTS.

Sem dúvida, afirma P. BONFANTE ${ }^{273}$, a interpretação lógica pode restituir o verdadeiro significado de um texto mesmo em oposição à sua expressão literal, mas para abandonar a interpretação literal convém que existam razões justificáveis, ao invés, o que se vê em A. ASCOLI são sérias razões que o significado literal não seja afastado.

\footnotetext{
${ }^{271}$ A. AsCOLI, Studi cit. (nota 266 supra), p. 328-329.

${ }^{272}$ Le singole cit. (nota 10 supra), p. 649.

${ }^{273}$ Le singole cit. (nota 10 supra), p. 650.
} 
Outra opinião de A. AsCOLI que é refutada por completo pelo autor é a que o referido fragmento, por si, não teria mais significado prático no direito justinianeu e que teria permanecido no Digesto como uma reminiscência histórica.

O segundo princípio a ser analisado, refere-se ao fato de que lucrativa pro herede usucapio teria sido submetida e revogada perante o herdeiro que intenta a hereditatis petitio, em virtude do senatusconsulto de Adriano.

L. ARNDTS ${ }^{274}$ teria recorrido a mais textos com o escopo de demonstrar que tal revogação ainda subsiste para o usucapião do herdeiro aparente no direito justinianeu.

As duas constituições de Diocleciano seriam uma evidência dessa assertiva.

C. $3,31,7$ :

"Hereditatis petitionem, quae adversus pro herede vel pro possessore possidentem exerceri potest, praescriptione longi temporis non submoveri nemini incongitum est, quum mixtae personalis actionis ratio hoc respondere compellat. A ceteris autem tantum specialibus in rem actionibus vindicari posse manifestum est, si nona gentis intentio per usucapionem vel longum tempus explosa sit".

C. 7, 34, 4:

"Hereditatem quidem petentibus longi temporis praescriptio nocere non potest. Verum his qui nec pro herede nec pro possessore, sed pro emptore vel donato seu alio titulo res quae hereditariae sunt vel fuerunt possident, cum ab his successio vindicari non possit, nihil haec iuris definitio
Ninguém desconhece que a petição de herança, a qual se pode intentar contra os que possuem como herdeiros ou possuidores não pode ser rechaçada pela longi temporis praescriptio, pois a natureza dessa ação mista pessoal obriga a responder isso. Mas é claro que, a respeito de outros possuidores, somente pode ser reivindicada por ações especiais reais caso a demanda do agente não tenha sido rechaçada pelo usucapião ou pela prescrição de longo tempo.

Certamente que aos que pedem uma herança, não pode prejudicar a longi temporis praescriptio. Mas em nada prejudica esta decisão do direito aos que não possuem como herdeiro e nem como possuidor, salvo por compra, doação, ou por outro título, bens que são ou foram da herança, posto que destes não

${ }^{274}$ Ueber die "Usucapio pro herede" cit. (nota 264 supra). 
Segundo P. BONFANTE ${ }^{275}$, o pensamento de A. AsCOLI pressupõe um debate sobre a natureza da ação hereditária e este autor teira concluído que as decisões imperiais justificamse por outra relação.

Para o citado romanista, o pensamento de A. AsCOLI trafega no seguinte sentido: se a petição de herança tivesse podido opor-se a praescriptio longi temporis, esta teria experimentado por efeito a total exclusão da ação, uma vez que o que se pretende por meio das exceções é buscar verdadeiras condições negativas da condenação ${ }^{276}$.

Logo, A. Ascoli teria entendido que Diocleciano, nos dois textos citados, afirma que a praescripio longi temporis não pode ter como finalidade servir como exceção para excluir a hereditatis petitionem, pois o herdeiro continua a ser prejudicado.

O texto não teria negado que com a usucapio ou com a longi temporis possessio pro herede o possuidor teria adquirido a propriedade ou outro direito real, o qual pudesse valer também contra o herdeiro.

Assim, caberia ao juiz, ao determinar uma eventual condenação, levar em consideração que ocorreu a prescrição para poder condenar o recorrido à restituição das coisas não prescritas, ao invés de dar espaço para uma verdadeira exceptio.

Argumenta P. Bonfante que esta teoria A. AsCOLI"è degna non solo di essere a preferenza rilevata, ma la sua eleganza, malgrado il troppo sutil ragionamento, potrebbe vincerla sulla intuitività banale dell'interpretazione dell'Arndts ${ }^{277}$,".

O mencionado romanista esclarece que sobre a revogação ou a anulação, não se nota nenhuma palavra na teoria de A. AsCOLI.

Ademais, observa o autor que o senatusconsulto de Adriano referia-se ao usucapião e à usucapio lucrativa, não à longi temporis praescriptio, talvez ainda desconhecida e muito menos à uma longi temporis praescriptio anômala ou lucrativa.

Assim como para o usucapião, uma vez que teria sido introduzida a longi temporis praescriptio, o justo título passou a ser exigido também a ela.

\footnotetext{
${ }^{275}$ Le singole cit. (nota 10 supra), p. 651.

${ }^{276}$ P. BONFANTE, Le singole cit. (nota 10 supra), p. 650.

${ }^{277}$ P. BONFANTE, Le singole cit. (nota 10 supra), p. 651.
} 
Logo, o possuidor pro herede não tendo um título especial apto a conduzi-lo a propriedade, isso fazia com que ele não pudesse se socorrer da longi temporis praescriptio.

O possuidor alega que é o verdadeiro herdeiro e, nesta capacidade, é levado a requerer a hereditatis petitionem, a qual, no tempo de Diocleciano e por um século a fio até os tempos de Honório e Teodósio, refere-se somente às actiones in rem especiais e não é submetida à longi temporis praescriptio.

Outro texto citado por L. ARNDTS ${ }^{278}$ é o seguinte rescrito de Caracalla, em C. 7, 29, 1:

"Cum pro herede usucapio locum non habeat, intelligis neque matrem tuam, cui heres extitisti, neque te usu mancipia ex ea causa capere posse".
Como queira que não tenha lugar o usucapião a título de herdeiro, tem entendido que nem tua mãe, da qual se tornasse herdeiro, nem você poderá usucapir por esta causa os escravos.

A opinião de L. ARNDTS se opõe à de A. ASCOLI, ao afirmar que locum non habeat indica inexistência, mas não revogabilidade.

P. BONFANTE ${ }^{279}$ afirma que o texto não é muito claro, pois foram extraídas partes dele e H. FitTing ${ }^{280}$ mencionava o texto como uma referência ao usucapião de coisas não hereditárias compradas do verdadeiro herdeiro.

Todavia, observa P. BONFANTE que este usucapião não seria pro herede, mas pro suo.

$\mathrm{O}$ autor defende a opinião que o texto se referia à usucapio lucrativa, a qual se negaria, na espécie, a possibilidade de ser aplicada ao caso e ser invocada pela parte por falta de qualquer dos seus requisitos especiais ${ }^{281}$.

Sobre a regra em questão, o texto, em última análise não traz mais do que dois precedentes.

O último argumento aduzido por L. ARNDTS refere-se precisamente ao texto do edito, em D. 43, 2, 1 pr.:

\footnotetext{
${ }^{278}$ Civilistische Schriften. II, p. 374, cit. por P. BONFANTE, Le singole cit. (nota 10 supra), p. 653.

${ }^{279}$ Le singole cit. (nota 10 supra), p. 653.

${ }^{280}$ Arch. für civ. Pr., 52, p. 258, cit. por P. Bonfante, Le singole cit. (nota 10 supra), p. 653.

281 Existe uma suspeita de interpolação citada por I. ALIBRANDI (Possesso, p. 128) em relação às palavras cum pro herede, etc., isso representaria a negativa do usucapião pro herede no texto de Caracalla. - P. BONFANTE, Le singole cit. (nota 10 supra), p. 653.
} 
"Ait Pretor: Quorum bonorum ex edicto meo illi possessio data est, quod de his bonis pro herede aut pro possessore possides possideresve, si nihil usucaptum esset, quod quidem dolo malo fecisti, uti desineres possidere, id illi restituas".
Disse o pretor: Desses bens que foi dada a posse pelo meu edito, restituirás o que possui pro herede e pro possessore ou o que possuirias se nada tivesse usucapido e o que tem desejado possuir dolosamente.

Para P. BONFANTE ${ }^{282}$, o texto deve ser interpretado literalmente. Nele se concede o interdito quorum bonorum mesmo contra aquele que usucapiu pro herede.

Observa esse autor que A. AsCOLI investe contra a opinião de L. ARNDTS em muitas infelizes tentativas, com o escopo de tentar escapar desta consequência.

Para A. AsCOLI o texto seria corrompido, pois onde se lê "esset", esse autor propõe que sei leia "est".

Todavia, essa correção proposta por A. ASCOLI, a qual teria se apoiado nas Basílicas, onde a expressão é traduzida como "nec usucepisti”, P. BONFANTE ${ }^{283}$ observa que ela muda radicalmente o sentido do fragmento.

Diante dessa observação, esse estudioso afirma que a correção se apresenta com tamanha simplicidade e grau de probabilidade, que não se vê mais vantagem em se recorrer ao texto genuíno.

O terceiro princípio relevante sobre a lucrativa pro herede usucapio, consiste no fato de que ela não é cabível contra o heres suus et necessarius.

Afirma o autor que este princípio que vigorou no direito clássico, teria sido formulado com base dois textos de Gaio (Inst. 2, 58; 3, 201) e ele é encontrado em um rescrito de Diocleciano quase com a mesma fórmula tradicional na compilação justinianeia.

$$
\text { C. 7, 29, 2: }
$$

"Nihil pro herede posse usucapi suis heredibus existentibus magis obtinuit".
Prevaleceu que nada se pode usucapir a título pro herede, existindo seus herdeiros.

\footnotetext{
${ }^{282}$ Le singole cit. (nota 10 supra), p. 654.

${ }^{283}$ Le singole cit. (nota 10 supra), p. 654.
} 
Aduz P. BONFANTE ${ }^{284}$ que no tempo de L.ARnDTS a interpretação que se fazia dos textos de Gaio era equivocada, praticamente o significado contrário, logo, não poderia esse estudioso ter desenvolvido essa correspondência de ideia.

Entretanto, agora A. AsCOLI seria forçado a render-se a esta evidência.

Para embasar a sua tese A. AsColi teria recorrido aos princípios de equidade e de sentimento moral, que teria induzido a estender ao usucapião do herdeiro aparente uma limitação própria da usucapio lucrativa, mesmo que em oposição ao direito e à lógica ${ }^{285}$.

P. BONFANTE, reconhecendo a criatividade argumento, salienta que "l'equità è un gran rifugio nei casi disperati ${ }^{286, "}$.

Assevera o autor que, às vezes, pode até ser necessário do ponto de vista do direito justinianeu inventar sutilezas interpretativas, contudo, o direito romano enquanto ciência histórica repudia esse tipo de solução.

Salvo se L. ARNDTS e os escritores alemães seus seguidores tivesse constatado a existência de outros princípios que sequer poderiam ser considerados como tal e que os textos justinianeus tivessem sido relacionados à usucapio pro herede, com exceção do princípio da própria antiga usucapio lucrativa.

A quarta premissa citada por P. BONFANTE ${ }^{287}$, refere-se ao fato de que a lucrativa pro herede usucapio é reconhecida apenas em relação à res hereditariae.

Essa regra, igualmente declarada também por Gaio (Inst. 2, 52; 3, 201) teria sido expressada de maneira diversa no seguinte texto justinianeu de Pompônio: D. 41, 5, 1:

"Pro herede ex vivi bonis nihil usucapi potest, etiamsi possessor mortui rem fuisse existimaverit".
Nada se pode usucapir pro herede, <em relação> aos bens de pessoa que não está morta, mesmo que o possuidor tenha acreditado que a coisa pertencia a uma pessoa morta.

\footnotetext{
${ }^{284}$ Le singole cit. (nota 10 supra), p. 655.

285 A. AsCOLI, Studi cit. (nota 266 supra), p. 357-359.

${ }^{286}$ P. BONFANTE, Le singole cit. (nota 10 supra), p. 656.

${ }^{287}$ Le singole cit. (nota 10 supra), p. 656.
} 
Observa P. BONFANTE ${ }^{288}$ que não haveria dificuldade em admitir o usucapião em relação aos objetos dos quais se acredita que fazem parte da herança, mas pertencem a pessoa viva, se o usucapião pro herede fosse um usucapião normal.

Cita como exemplo, um caso relacionado ao legado, onde se estabeleceu o princípio contestado por Javoleno e pelo próprio Pompônio.

Javoleno, D. 41, 8, 5:

"Ea res, quae legati nomina tradita est, quamvis dominus eius vivat, legatorum tamen nomine usucapietur".

Pompônio, D. 41, 8, 6:

"si is, cui tradita est, mortui esse existimaverit".
O que foi entregue por causa de um legado, ainda que seu proprietário esteja vivo, se poderá usucapir pro legato.

se aquele a quem se entregou tiver acreditado que pertencia a uma pessoa já morta.

Para P. BONFANTE ${ }^{289}$, os textos não escondem que a aplicação do princípio da usucapio lucrativa ao usucapião em favor do herdeiro aparente poderia receber uma explicação com base na mera diferença de natureza que possuem a herança e o legado.

Ressalta, ademais, que este princípio estabelece diferenças entre a herança e o legado:

A causa legati é constituída sobre aquele objeto que se pretende adquirir ou usucapir.

O testador renuncia a um objeto do qual esse renunciante não será proprietário, mas existe uma renúncia efetiva em favor do usucapiente.

Portanto, essa situação recai na forma normal do usucapião.

De outro modo, a herança pode ser constituída apenas em relação aos direitos que possuía o testador.

O fato de o falecido ter deixado ou não o testamento, não significa que renunciou em favor do usucapiente a herança dos bens que não lhe pertenciam.

\footnotetext{
${ }^{288}$ Le singole cit. (nota 10 supra), p. 656.

${ }^{289}$ Le singole cit. (nota 10 supra), p. 657.
} 
Entretanto, adverte P. BONFANTE ${ }^{290}$ que sua tese particular não se baseia sobre esse entendimento, logo, o quinto princípio deve ser levado em consideração: "Servus pro herede possidere non potest”. Esse brocardo é citado por Paulo em D. 41, 3, 4, 4.

Para o autor, essa uma regra intrigante, pois nela se pretende conceber a usucapio pro herede como usucapião comum.

CUJÁCIO, cujo pensamento foi superado, teria repetido o principio em uma forma ainda mais crua: "Servus pro emptore, pro donato et ex omni causa domino possidere potest, pro herede non item, sibi nullo modo" ${ }^{291}$.

P. Bonfante sustenta que este autor entrega uma "spiegezione banale $e$ contraddicente alla dichiarizione che ha fatto del suo contenuto": "Hoc est verissimum: quia nec servus heres esse potest 292 ",

Salienta o autor que a opinião dominante considerava esse princípio como uma mera consequência do fragmento de Paulo, D 41, 3, 4.

Acrescenta, outrossim, que H. FITTING teria também tentado explicar o fragmento, de modo que deve ser lido possidere, no sentido de adquirir, ao invés de possidere, no sentido de possuir, mas considerando que o verbo é dúbio, o romanista italiano não vê uma possibilidade de se avançar com esse argumento.

O princípio acomodaria-se, então, perfeitamente em conformidade à natureza da usucapio lucrativa.

Diz Javoleno (D. 41, 2, 24) que o escravo não possui diante do seu senhor, senão ex iusta causa, assim, o representaria apenas na possessio civilis, que é uma relação defendida mediante ação, logo, um direito.

Ademais, justifica essa representação, posto que os direitos vem a fazer parte do seu pecúlio.

No entanto, salienta o citado romanista, que não se trata se uma possessio civilis a posse sobre a qual se baseia a usucapio lucrativa, logo, ela não dá ensejo à defesa mediante uma ação específica ou através da actio Publiciana.

Em resumo, ela não é um direito propriamente dito.

\footnotetext{
${ }^{290}$ Le singole cit. (nota 10 supra), p. 657.

${ }^{291}$ CujÁCIO, Ad. Tit. De Us., L. 4, § Servus, I, 1111 (Venetiis, 1758, I, p. 708) cit. por P. BonfanTE, Le singole cit. (nota 10 supra), p. 657.

${ }^{292}$ Le singole cit. (nota 10 supra), p. 657.
} 
Por essa razão, considerando a máxima "in peculio servi non est" o escravo não poderia possuir a coisa com base nesse título.

Deve-se atentar, para tanto, ao texto de Paulo, D. 41, 3, 4, 5:

"Fructus et partus ancillarum et foetus
$\begin{aligned} & \text { Eecorum, sossível usucapir os frutos, os filhos das } \\ & \text { possunt". }\end{aligned}$

Quanto a este parágrafo, P. BONFANTE ${ }^{293}$ explica que ele é incompreensível, pois dá lugar a uma margem de interpretações absurdas, tanto em matéria de usucapião como em relação à aquisição dos frutos ou era deixado de lado como um texto do qual nada se extraía.

Realmente, adverte o estudioso em comento, observar o motivo pelo qual o herdeiro pode usucapir partes da escrava quando elas não pertenciam ao falecido, e falar ao mesmo tempo dos frutos e dos fetos dos animais pode soar como algo complicado.

Contudo, toda dificuldade desaparece quando se refere à usucapio lucrativa.

Esclarece P. BONFANTE ${ }^{294}$ que o possuidor pro herede não adquire nada imediatamente, tampouco os frutos que nascem presos às coisas, haja vista que a aquisição por separação seria um direito do possuidor de boa-fé e ele não pode ser considerado dessa forma.

Contudo, excepcionalmente, seria possível usucapir as coisas que pertencem ao falecido no prazo de apenas um ano.

Outra dúvida que remanesce recai sobre a possibilidade de ele usucapir o que nasce preso deles.

Sendo partes da escrava, são frutos, já que estes objetos nunca pertenceram ao falecido.

Nessa esteira, a possibilidade de se usucapir aquilo que nasce preso às coisas e que nunca pertenceram ao falecido, Paulo decide que é possível usucapir, pois, em substância, essas coisas também são bens hereditários.

No fragmento D. 41, 3, 4, 24, Paulo, discorrendo das res vi possessae, subtrai o usucapião e volta a fazer observações acerca da possessio pro herede.

$\overline{{ }^{293} \text { Le singole cit. (nota } 10 \text { supra), p. } 658-659 .}$ 
Tal entendimento é extraído, segundo P. BONFANTE ${ }^{295}$ da leitura conjunta deste parágrafo com o anterior, porque é relevante a correlação que o jurisconsulto estabelece entre a possessio malae fidei e a possessio pro herede.

D. 41, 3, 4, 23:

"Ceterum etiamsi mala fide fundum me possidentem deieceris et vendideris, non poterit capi, quoniam verum est vi possessum esse, licet non a domino".

D. 41, 3, 4, 24:

"Idem dicendum est in eo, qui eum expulit, qui pro herede possidebat, quamvis sciat esse hereditarium, quoniam vi possidet".
De outra forma, se você tiver me expulsado da posse de um imóvel, ainda que eu o possuísse de má-fé e o tivesse vendido, não poderá usucapir o imóvel, pois é verdade que se dá uma posse violenta do mesmo, ainda que não seja contra o proprietário.

O mesmo deve ser decidido quando alguém expulsou aquele que possuía <um imóvel para usucapir-lo> pro herede, embora sabendo que o imóvel era de herança, pois possui por um ato de violência.

Observa o autor que o jurisconsulto Gaio, nas leis imediatamente sucessivas, declara que as vi deiectio estabelecem ao usucapião e à posse uma interrupção natural.

Não importa que se trate de um verdadeiro possuidor de boa-fé, ou de um daqueles possuidores, aos quais de tal maneira excepcional é dado usucapir: "ac ne illud quidem interest, pro suo quisque possideat an ex lucrativa causa ${ }^{296,}$.

Em relação ao fragmento, Ilustra P. BONFANTE que referem-se a "parole che per diritto giustinianeo hanno quel senso che Dio vuole; ma certo non possono alludere al comum titolo lucrativo e gratuito" 297 .

\footnotetext{
${ }^{294}$ Le singole cit. (nota 10 supra), p. 659.

${ }^{295}$ Le singole cit. (nota 10 supra), p. 659-660.

${ }^{296}$ Gaio, D. 41, 3, 5 in fine:Não importa que alguém possua a coisa como sua ou por causa lucrativa".

${ }^{297}$ P. BONFANTE, Le singole cit. (nota 10 supra), p. 660.
} 


\subsection{O usucapião pro herede e a ação de furto}

O usucapiente pro herede não possui ação de furto, a qual é cabível ao normal possuidor ad usucapionem.

Javoleno, em D. 47, 2, 72 (71), 1:

"Eius rei, quae pro herede possidetur, furti actio ad possessorem non pertinet, quamvis usucapere quis possit, quia furti agere potest is, cuius interest rem non subripi, interesse autem eius videtur, qui damnum passurus est, non eius, qui lucrum facturus esset".
Aquele que possui uma coisa como se fosse herdeiro, não dispõe da ação de furto, embora possa usucapir; isto é assim porque pode exercitar a ação de furto aquele que tem interesse que a coisa não seja furtada, e considera-se que tem interesse aquele que pode sofrer um dano, não aquele que poderia ter experimentado um lucro.

Conforme o autor, com base nas últimas palavras (lucrum facturus esset) A. AsCoLI ${ }^{298}$ afirma que esse texto não faz referência ao herdeiro aparente, mas somente ao possuidor da usucapio lucrativa.

Por esse motivo, é de rigor fazer a distinção entre as duas espécies, uma vez que se verificou que não há princípios onde as duas sejam divergentes.

Deve-se, identificar, ainda, se o texto não fornece um argumento válido para justificar o tratamento especial do herdeiro aparente.

\subsection{O usucapiente pro herede e a actio Publiciana (impossibilidade).}

O sétimo princípio citado P. BONFANTE, concerne à impossibilidade do usucapiente pro herede valer-se da Publiciana.

Acentua o autor que em relação a esta questão "abbiamo di ciò una prova negativa che per avventura vale più de cento positive 299 ".

\footnotetext{
${ }^{298}$ Studi cit. (nota 266 supra), p. 333.

${ }^{299}$ P. BONFANTE, Le singole cit. (nota 10 supra), p. 661.
} 
Entre as iustae causae das ações Publicianas, as quais teriam sido enumeradas de forma precisa por Ulpiano e Paulo de modo que assemelham-se a verdadeiras causas de usucapião, não se faz menção à uma presumida hereditas ou à posse pro herede, tampouco nos textos relacionados ao assunto fora do título da Publiciana.

Indaga P. BONFANTE ${ }^{300}$ se agora, reencontrados todos os princípios em comum, se poderia se afirmar que a usucapio lucrativa e a usucapio pro herede do herdeiro aparente são dois institutos diversos.

E acrescenta o estudioso à sua indagação: em relação às fontes prejustinianeias e justinianeias, que mantém as raízes de tudo, onde se encontraria um indício de uma distinção entre as duas espécies de usucapião pro herede?

Esclarece o autor que jurisconsultos como Pompônio e Paulo, Juliano e imperadores como Caracalla, Javoleno e Diocleciano falam de um único instituto, singularmente disciplinado, em termos iguais: possessio ou usucapio pro herede.

Assevera P. BONFANTE ${ }^{301}$ que fazendo uma ruptura à época de Marco Aurélio, percebe-se que uns falarão do herdeiro aparente, outros, da lucrativa pro herede usucapio.

A. AsCOLI $^{302}$ teria afirmado que nos jurisconsultos posteriores a Marco Aurélio não se encontra mais remissões da existência deste instituto, no entanto, P. BONFANTE não concorda com tal opinião.

O motivo de dessa discordância, reside no fato de que ora enunciando princípios, com exceção ao instituto anômalo (Servus pro herede, etc., Fructus, etc.), ora aproximando-o do possuidor de má-fé, Paulo se expressa sobre a possessio pro herede.

Diocleciano cita uma regra, a qual era para Gaio própria da lucrativa usucapio, enquanto Caracalla responde sobre uma usucapio pro herede, negando que ela seria cabível.

Considerando que Marco Aurélio não revogou nada, os jurisconsultos não se referem à usucapio lucrativa pro herede, mas a um usucapião distinto do antigo.

Em síntese, todos eles usam termos próprios de Gaio e Pompônio, Javoleno e Juliano.

Feitas estas observações e uma vez iniciada a interpretação pelo caminho certo, o autor sustenta que os indícios e as provas começam a aparecer.

\footnotetext{
${ }^{300}$ Le singole cit. (nota 10 supra), p. 661.

${ }^{301}$ Le singole cit. (nota 10 supra), p. 661-662.

${ }^{302}$ Studi cit. (nota 266 supra), p. 324.
} 
Refere-se o romanista ao fato que o usucapião do herdeiro aparente já era regular e diferente do antigo no direito clássico.

Além disso, o título pro herede era considerado como se fosse título verdadeiro.

Ele aparece no Digesto em apenas quatro fragmentos, contudo, não deve ser cogitado o texto D. 41, 5, 3 de Pompônio, pois ele se refere ao usucapião do herdeiro verdadeiro, mas chamado de pro herede por equívoco.

Já os demais enunciam princípios que condizem perfeitamente à usucapio lucrativa. São os textos D. 41, 5, 2, de Juliano, D. 41, 5, 1, de Pompônio e D. 41, 5, 4 de Paulo .

Finalmente, um indício de natureza mais sutil, que para P. BonfANTE ${ }^{303}$ é o que melhor acomoda em favor da sua tese: a oposição singular entres os títulos pro emptore e o título pro herede, mesmo quando se enunciam princípios que valem tanto para o usucapião ordinário quanto para a lucrativa usucapio.

Conforme o autor, isso pode ser constatado nos seguintes textos, além do texto de Javoleno, D. 41, 3, 21:

$$
\text { Pompônio, em D. 41, 4, } 6 \text { pr.: }
$$

"Qui, cum pro herede vel pro emptore usucaperet, precario rogavit, usucapere non potest: quid porro inter eas res interest, cum utrubique desinat ex prima causa possidere, qui precario vult habere?".
Aquele que, usucapindo pro herede e pro emptore, pediu a coisa em precário, não pode usucapir. Com efeito, qual a diferença que existe em um ou outro caso, se em ambos <os casos> deixar o posseiro de possuir pela primeira causa?.

Papiniano, em D. 41, 3, 44, 5, primeira parte:
"Non mutat usucapio superveniens pro
O usucapião que se procede pro emptore ou emptore vel pro herede, quo minus pignoris persecutio salva sit". pro herede, não impede que a aquisição da garantia permaneça a salvo.

Observa P. BONFANTE ${ }^{304}$ que, nos textos citados, evidencia-se que não estão conjugados o título pro emptore e o título pro herede, exceto como tipos, um relacionado ao usucapião normal e outro que se refere à usucapio lucrativa.

\footnotetext{
303 Le singole cit. (nota 10 supra), p. 663.

${ }^{304}$ Le singole cit. (nota 10 supra), p. 663.
} 
Essa hipótese se assemelharia àquela que põe o título pro suo em oposição à lucrativa causa, narrada no texto de Gaio (D. 41, 3, 5).

Da análise dos princípios P. BONFANTE ${ }^{305}$ conclui que a usucapio pro herede era no direito clássico um único instituto, e sempre usucapio lucrativa e anômala.

Ressalta, ainda, que nem mesmo para aqueles que defendem o título putativo, a crença de ser herdeiro seria capaz, nesse caso, de gerar um título de usucapião ou qualquer outro tipo de causa.

Depois do senatusconsulto de Adriano, teria sido efetuada uma distinção entre possessio pro herede e possessio pro possessore, a qual teria recaído somente em relação à petição de herança, em decorrência da boa ou má-fé.

Em relação ao usucapião, nem a introdução do crimen expilatae hereditatis e nem Adriano o teria destruído.

Ele teria sobrevivido até Justiniano com suas características especiais, e na sua posição anômala em relação ao usucapião com base na posse ex iusta causa ou pro suo.

Aduz P. BonfAnTE ${ }^{306}$ que Justiniano fixou novos prazos para a aquisição das coisas móveis e imóveis, desaparecendo então o único termo anual do usucapião lucrativo.

Ademais, passou-se rapidamente a exigir a boa-fé para todo usucapião sob o modelo da longis temporis praescriptio.

A conformação da longi temporis praescripio pode ser verificada no texto C. 7, 31, 3:

"Hoc tantummodo observando, ut in his omnibus casibus ab initio bona fide eam capiat, secundum quod exigit longi temporis praescriptio, et ut continuetur ei possessio etiam anterioris iusti possessoris et connumeretur in decennium vel viginti annorum spatium vel triennium, quod in rebus mobilibus observandum esse censemus, ut in omnibus iusto titulo possessionis antecessoris iusta detentio, quam in re habuit, non
Deve-se observar somente isto, que em todos os casos a posse seja tomada de boa-fé desde o princípio, segundo aquilo que exige a longi temporis praescriptio, que se continue para ele a posse também do anterior justo possuidor e se conte até dez anos ou até o tempo de vinte anos ou até um triênio. O que mandamos também que seja observado a respeito dos bens móveis, de modo que ninguém interrompa a justa retenção da posse,

\footnotetext{
${ }^{305}$ Le singole cit. (nota 10 supra), p. 664.

${ }^{306}$ Le singole cit. (nota 10 supra), p. 664.
} 
interrumpatur ex posteriore forsitan alienae rei scientia, licet ex titulo lucrativo ea coepta est". que com justo título tinha o antecessor sobre a coisa, talvez por conhecimento posterior de que a coisa era alheia, ainda que tenha iniciado em virtude de um título lucrativo.

Consequentemente, o usucapião pro herede passa a corresponder ao usucapião normal, uma vez que foram rejeitadas duas das suas características fundamentais (termo anual e indiferença da boa ou má-fé), os textos relacionados a ele foram inseridos nas compilações e foram acolhidos todos os princípios especiais menos exorbitantes.

Sustenta P. BONFANTE ${ }^{307}$ que estes princípios relacionados à lucrativa usucapio podem até não justificar um novo ponto de vista, mas não se pode rejeitá-los e considerá-los uma reminiscência histórica, a exemplo do que pretende A. AsCOLI.

De todo modo, esclarece o autor, a virtude desses princípios, verificado o completo abandono do título verdadeiro no sentido pretendido pelos jurisconsultos clássicos, esse usucapião constitui no âmbito do usucapião normal uma espécie bastante singular e reveladora da matéria feita pelos compiladores.

Diz o autor que um pequeno espanto o acomete ao ver reaparecer, na forma de refutação implícita à sua tese, a velha opinião de uma usucapio pro herede de tipo normal, como fez por último A. ASCOLI ${ }^{308}$ e também S. PEROZZI ${ }^{309}$, apesar deste assumir algumas das posições particulares P. BONFANTE.

Refutando a opinião de S. PEROZZI, P. BONFANTE diz: “il modo con cui egli ripresenta questa vecchia opinione è per me così bizarro, che io temetti lungamente di non comprendere le sue parole”.

Segundo P. Bonfante, S. Perozzi considera que no direito clássico, aquele que acreditava ser herdeiro, sem sê-lo, não poderia usucapir nem com a usucapio lucrativa.

O autor nega primeira proposição de S. PEROZZI, isto é, a negação da usucapio lucrativa, admitindo a segunda, a negação da usucapio ordinária, mas esta, por ausência de título, que para ele parece expressar o motivo de exclusão mais adequado em relação àquilo que S. PEROZZI defende.

\footnotetext{
${ }^{307}$ Le singole cit. (nota 10 supra), p. 665.

${ }^{308}$ Studi cit. (nota 266 supra), p. 324.

${ }^{309}$ Istituzioni, II, p. 388, cit por P. BONFANTE, Le singole cit. (nota 10 supra), p. 666.
} 
Verifica, ademais, que esse autor entende que essa regra somente viria a ser alternada no direito justinianeu.

A linha que seria defendida por S. PEROzzI seria no sentido de que o caso do usucapião (ordinário) torna-se possível somente admitindo o título pro suo, e essa modalidade de usucapio tem lugar precisamente no direito justinianeu, embora ele também seja chamado de usucapio pro herede.

Observa P. Bonfante que S. Perozzi ${ }^{310}$ mantém de forma agrupada os mesmos princípios que ele defende e cita-os quase todos, porém, S. PEROZZI acredita que Justiniano os teria aplicado a um usucapião criado pela primeira vez, o qual ele chama de usucapio pro herede, e isso é o teria feito se aproximar às hipóteses da usucapio pro herede clássica, ou seja, a usucapio lucrativa.

O autor sustenta que S. PEROzZI acreditava que os textos nos quais se admite o usucapião do herdeiro aparente de boa-fé são interpolados, contudo, foram mantidos conscientemente nos textos

Seriam para ele interpolados, também, os princípios da antiga usucapio pro herede.

Ao contrário, P. BONFANTE ${ }^{311}$ sustenta que dessa sugerida série de interpolações, pode-se afirmar que não existe o menor vestígio nos textos examinados.

Justifica sua crítica fundamentando que o discurso de S. PEROzZI, apesar de muito simples, enfrenta severas dificuldade para ser admitido.

Isso porque, não se pode imaginar o motivo dessa alegada e estranha reforma, as quais teriam sido feitas após a devida consideração de Justiniano.

Não se poderia entender, na opinião de P. BONFANTE ${ }^{312}$, por qual motivo o imperador, deliberadamente, teria repescado princípios de um danificado instituto para aplicá-lo a uma forma de usucapião criada por ele no direito justinianeu que, como tudo leva a crer, admite ainda o título putativo.

Examinando detalhadamente os argumentos com os quais S. PEROzZI tenta justificar a sua opinião, P. BONFANTE chega às seguinte conclusões:

S. PEROZZI, primeiramente, rebate aquele que seria o ponto de partida do pensamento de P. BONFANTE, e que não ter sido contrastado por ninguém, isto é, a usucapio lucrativa pro

\footnotetext{
${ }^{310}$ Istituzioni (nota 300 supra), p. 388.

${ }^{311}$ Le singole cit. (nota 10 supra), p. 666.
} 
herede valia-se também para aquele que se acreditava herdeiro.

Sustenta S. PEROZZI que a usucapio lucrativa, que não é usucapião - premissa da qual não concorda P. BONFANTE -, serve para beneficiar apenas àqueles que não se creem herdeiros.

Alega S. Perozzi de que parte da doutrina sustenta que usucapio pro herede clássica poderia beneficiar a quem se crê herdeiro, citando A. BRINZ como exemplo.

Sustenta P. Bonfante ${ }^{313}$ que Gaio não poderia, em tais hipóteses, chamá-la de improba sem fazer as devidas distinções, tampouco seria justificada a norma do tempo de Adriano, pela qual, igualmente sem distinções, se revoga toda usucapio pro herede.

Observa o autor que Gaio se referiu ao modo pelo qual é lícito a qualquer pessoa iniciar esse usucapião, uma vez que sua forma jurídica prescinde da bona fides.

Afirma o autor que seria estranho se o possuidor em boa-fé, pro herede, depois do decurso de um ano, não pudesse se opor ao usucapião e reivindicar a coisa.

Salienta, ademais, não é porque a lei dispensa a boa-fé que por isso ela exigiria como requisto a má-fé.

O citado romanista acrescenta que essa opinião de S. PEROzZI ${ }^{314}$ é, indubitavelmente, em contraste não só com BRINZ, citado por ele, mas com todos os outros escritores, os quais acreditavam que, nas origens, aquele que se apresentava a ocupar os bens vagos seria regularmente o presumido herdeiro.

Outrossim, em relação à norma de Adriano que revoga todo usucapião pro herede, seja perante a heredes petitionem, seja diante do interdito Quorum bonorum (D, 43, 2, 1), lhe parece obscura a forma pela qual S. PEROZZI gostaria que abolisse a eficácia e distinguisse entre boa ou má-fé.

Em exegese, esse autor sustentaria que o fragmentos D. 41, 3, 33, 1 e D. 41, 3, 29 são interpolados, quanto ao primeiro, em hoc amplius a videbitur, conforme A. PERNICE, Labeo, II, 1, 2, p. 430, nota 1, e também em ita tamnen até o final do texto.

Ademais, são claramente contrários os fragmentos C. 7, 29, 4, com termos nec obtentu veluti ex hereditate, C. 7, 33, 4 e D. 41, 3, 4, 24, onde a posse na usucapio pro herede seria equiparada à posse em geral em má-fé.

\footnotetext{
${ }^{312}$ Le singole cit. (nota 10 supra), p. 667.
} 
No entanto, assevera P. BONFANTE ${ }^{315}$ que não há o menor traço formal de interpolação nos dois primeiros textos.

Para o autor, seria bastante provável, como sustenta S. RICCOBONO, que das palavras ita tamen em diante tenha-se em na D. 41, 3, 29 uma nota de Pompônio a Sabino.

Já em relação às duas constituições do Codex, diante seu teor, esses fragmentos referiam-se ao usucapião do herdeiro verdadeiro sobre coisas que falsamente se acreditavam hereditárias (obtentu velut ex hereditate quod alienum fuit!) e não em relação ao herdeiro aparente, de boa ou má-fé.

E quanto ao usucapião, ele é negado, pois, o ius sucessionis não é iustus titulus, como diz o segundo texto.

De resto, P. BONFANTE ${ }^{316}$ alega que basta uma reflexão para concluir que não se trata do nosso usucapião, uma vez que a hipótese, seja de boa ou má-fé, exige que se refira à res hereditaria.

Em relação aos fragmentos D. 41, 3, 4, 24 e a D. 41, 3, 5, o autor afirma que S. PEROZZI $^{317}$ não prova nada através deles, exceto que a possessio pro herede dos jurisconsultos clássicos é oposta à possessio ex iusta causa, à possessio bonae fidei e que se amolda conforme a estrutura anômala da possessio et usucapio lucrativa.

Na terceira proposição em que S. PEROZZI confronta o pensamento de P. BONFANTE ${ }^{318}$, ele menciona que a última regra trazida no texto D. 47,2, 72, 1 corresponde à regra comum, a qual nega a ação de furto aos possuidores de má-fé.

Responde o romanista confrontado que a possessio pro herede, não havendo nunca título e tampouco a boa-fé, não pode ser emparelhada com a posse de má-fé.

Para o autor, esta obscuridade acerca da doutrina da causa parece insistir em permanecer nas mentes dos mais competentes estudiosos, pois a análise dos textos revela o método mecânico com o qual os compiladores agiam e a inteligência obscura que tinham acerca da iusta causa.

Certamente, para P. BONFANTE ${ }^{319}$, estamos diante de uma impassível reforma, a qual

\footnotetext{
${ }^{313}$ Le singole cit. (nota 10 supra), p. 666-667.

${ }^{314}$ Istituzioni (nota 300 supra), p. 388.

${ }^{315}$ Le singole cit. (nota 10 supra), p. 668.

${ }^{316}$ Le singole cit. (nota 10 supra), p. 668.

${ }^{317}$ Istituzioni (nota 300 supra), p. 388.

${ }^{318}$ Le singole cit. (nota 10 supra), p. 668.
} 
refere-se a um dos mais complexos e característicos exemplos da sobrevivência históricojurídica.

Conclui o autor, que não obstante o usucapio pro herede tenha sido admitido por Justiniano, não é certo que possa chamá-lo de iusta causa.

${ }^{319}$ Le singole cit. (nota 10 supra), p. 668. 


\section{CONCLUSÃO}

A análise dos textos romanos nos deixa claro que os romanos - especialmente os clássicos, quando esteve em evidência a admissão da causa putativa -, valeram-se de uma pluralidade de soluções em relação à cada singularidade que se apresentava sobre a à iusta causa usucapionis.

Em relação à usucapio pro derelicto, as fontes romanas parecem negar o título putativo. Esse é o entendimento de P. BonfANTE ${ }^{320}$ em relação aos fragmentos de Paulo, D. 41, 7, 4, onde se lê "is quod pro derelicto habitum est et haberi putamus".

A mesma conclusão se extrai dos fragmentos de Juliano, D. 41, 7, 7, em que cita o exemplo das coisas lançadas de um naufrágio e, em D. 41, 7, 6, onde, categoricamente, o jurisconsulto afirma que a falsa existimatio jamais poderá substituir a boa-fé. Esse, para o autor, é uma verdadeira declaração da iusta causa verdadeira.

Quanto ao usucapio pro soluto, em D. 41, 3, 33, 3, caso em que Juliano trata da hipótese da possibilidade de aquisição de um imóvel, o qual foi dado como pagamento de uma estipulação, o autor reconhece a existência de uma iusta causa, entretanto, ela não deveria ter sido dogmaticamente desenvolvida pela traditio, mas sim pelo termo genérico pro suo.

Já o texto de Pompônio, D. 41, 10, 3, o qual P. BonfAnte ${ }^{321}$ cuidou dentre as hipóteses de usucapião pro soluto, não obstante o texto tenha sido encaixado pelos compiladores no título pro suo, o autor concorda que a fattispecie "traditio ex causa, quam veram esse existimo" realmente conduz o intérprete à ideia da admissão do título putativo, todavia, isso seria um equívoco doutrinário decorrente da má compreensão da designação pro suo.

Isso porque na hipótese narrada por Pompônio, a tradição ocorre pela própria traditio ex iusta causa, além disso, o jurisconsulto parece indiferente em relação ao fato do título ser real ou putativo. O que ele faz, na verdade, é dar um peso maior à boa-fé.

A primeira parte do texto de Paulo, D. 41, 3, 48, trata da hipótese de alguém que, acreditando ser devedor, entrega algo a um credor como pagamento.

\footnotetext{
${ }^{320}$ Le singole cit. (nota 10 supra), p. 554-555.

${ }^{321}$ Le singole cit. (nota 10 supra), p. 559-560.
} 
O usucapião ocorrerá somente se esse credor acreditar que a dívida existe.

Todavia, ao que se depreende da análise do restante do fragmento, a conclusão que se extrai é que Paulo viu a necessidade de uma real emptio-venditio bonae fidei.

A principal observação que faz P. BONFANTE ${ }^{322}$ - ainda que a singularidade referente ao momento da boa-fé na compra e venda tenha chamado mais a atenção da doutrina -, reside no fato de que a emptio-venditio, ainda que possa ser, não é essencialmente direcionada à aquisição da propriedade e assim como cada um dos outros contratos precedentes à solutio real, ela é uma obrigação ad dandum.

Isso faz com que a solutio pura e simples de compra e venda não possua, por si, o caráter de iusta causa de aquisição real e de usucapião, mas não se cogita, na hipótese, a admissão de um título putativo.

Segundo P. BonfANTE ${ }^{323}$, a mais perfeita explicação acerca do título pro soluto é o texto de Hermogeniano, D. 41, 3, 46, onde expõe um evento de datio in solitum.

Para o autor, a solutio (causa solvendi) é uma modalidade de aquisição tanto para a tradição como para o usucapião, entretanto, o que se exige é que a obrigação precedente, i.e, a causa remota, não seja injusta.

Observa, ademais, o mencionado romanista, que até mesmo o pagamento de uma obrigação inexistente é um título real, logo, aqueles que defendem a existência de um título putativo em relação a esta causa, parecem equivocar-se na interpretação.

A modalidade pro donato, em regra, é outra onde se verifica sem maiores dificuldades a exigência do título verdadeiro.

Paulo, em D. 41, 6, 1 pr., de maneira clara manifesta-se que pode usucapir pro donato aquele a quem tenha sido entregue algo como doação.

Não bastaria a crença, mas sim a efetiva doação. A continuação do fragmento conduz à mesma conclusão acerca da exigência da iusta causa verdadeira.

A primeira parte do fragmento de Nerácio, D. 21, 1, 44, tem-se, provavelmente, o caso mais interessante em relação à eventual admissibilidade do título putativo.

A hipótese narra o fato de uma mulher que recebe em doação uma coisa de um estranho, mas a coisa pertencia ao marido dela, mas nem ela, nem o marido, e nem o estranho

${ }^{322}$ Le singole cit. (nota 10 supra), p. 579 
sabiam dessa situação. Nesse caso o usucapião era autorizado, pois não houve má-fé de nenhum dos envolvidos.

Todavia, na segunda parte do fragmento Nerácio adverte que se o marido ficou sabendo de que a coisa era dele antes do usucapião se consumar e, podendo reivindicá-lo, não quis fazê-lo, o usucapião seria interrompido, consequentemente, a coisa passaria a ser considerada como doada pelo marido.

Assim, na primeira a hipótese, verifica-se a boa-fé dos envolvidos, contudo, se a mulher soubesse da situação da coisa não usucapiria, pois a posse passaria a ser iniusta, mas se o marido soubesse da situação e não reivindicasse a coisa, ter-se-ia uma doação propriamente dita.

O dote guarda considerável semelhança com a doação, exceto pelo fato de este é causa gratuita, enquanto aquele é causa obrigatória.

Essa prestação perpétua que acompanha toda a existência dos direitos, afetando-lhes a natureza, comporta uma série de singularidades.

Ulpiano, em D. 41, 9, 1, 2, traz uma hipótese de usucapião antes do casamento.

O caso trata a respeito de uma coisa, a qual teria sido entregue pela noiva ao seu futuro marido antes do casamento.

Primeiramente, deve ser levado em consideração a vontade da noiva.

Se ela tinha a intenção de que a coisa se revertesse ao marido somente após o casamento, não seria admitido o usucapião em nenhuma hipótese, entretanto, se a intenção da noiva era a de que o marido se tornasse dono imediatamente, seria cabível o usucapião, mas na modalidade pro suo.

A primeira conclusão que se extrai do fragmento de Ulpiano é que somente será considerado o dote, se efetivamente ocorrer o casamento, mas ele não será um usucapião pro dote, mas sim pro suo.

O principal elemento valorado pelo jurisconsulto no texto é a vontade da mulher. A intenção dela é que determinará o resultado.

Adverte P. BonfANTE ${ }^{324}$, ademais, que não é porque a usucapio ocorrerá pro suo que se terá no caso um título putativo.

${ }^{323}$ Le singole cit. (nota 10 supra), p. 562. 
Em relação ao caso esculpido no fragmento D. 41, 9, 2, onde Paulo trata das coisas dadas por estimação antes do casamento, não se usucapirá nem pro emptore e nem pro suo.

Um dos casos que oferece interpretação das mais complexas, é o texto de Próculo, D. $23,3,67$, referente ao casamento de uma escrava que se casa e, por conta disso, entrega uma quantia de dinheiro em dote ao marido.

Esse dinheiro não será considerado do marido, pois a escrava não poderia sequer ter se casado, salvo, se o marido usucapisse pro suo, comprovando o erro de fato, i.e, que acreditava que a mulher fosse livre.

Tem-se, no caso, a valorização da boa-fé do marido para conduzi-lo ao usucapião da soma em dinheiro.

Ressalta-se, outrossim, que ainda que a escrava fosse posteriormente libertada em nada alteraria a situação dos fatos, pois a causa da posse seria a mesma e, portanto, iniusta, logo, a existência de um título seria impossível.

Para P. BONFANTE, não se pode afirmar a partir do texto a existência de um título putativo, pois, mais uma vez, a boa-fé é que foi levada em consideração.

Outrossim, o próprio autor observou que em relação a esse texto de Próculo foi cogitada a interpolação por A. PERNICE ${ }^{325}$.

L. VACCA nos chama a atenção para a escusabilidade do erro, a qual, por si, foi suficiente para desconstituir a causa dotal e alterar a situação da coisa para uma posse pro suo (e não uma iusta causa) e essa posse é suficiente para o usucapião.

O título pro emptore, certamente um dos mais importantes para o estudo da iusta causa, comporta algumas observações.

Primeiramente, deve-se observar a advertência que faz P. BONFANTE ${ }^{326}$ em relação à compra e venda real:

O autor afirma que reduzir o ato da compra e venda real em obrigação e pagamento ou considerar que todo negócio consiste em um pagamento concomitante ao surgimento da obrigação, trata-se de um erro gravíssimo, o qual foi gerado pela obscuridade que reina na doutrina sobre a causa.

\footnotetext{
${ }^{324}$ Le singole cit. (nota 10 supra), p. 572.

${ }^{325}$ P. BONFANTE, Le singole cit. (nota 10 supra), p. 678-679.

${ }^{326}$ Le singole cit. (nota 10 supra), p. 576-577.
} 
Já na compra e venda obrigatória, o que deve ser levado em consideração é o pagamento, contudo, no que se refere ao usucapião, ele poderia ser nomeado pro soluto.

Nessa linha, quando a compra e venda ocorre como cumprimento de obrigação, o contrato é apenas a causa remota, que poderia ser tranquilamente putativa, pois a existência do título verdadeiro deverá ser identificada na sua causa próxima, a solutio.

Um texto fundamental acerca da compra e venda obrigatória, já comentado acima, é o fragmento D. 41, 3, 48, de Paulo.

A segunda parte do fragmento apresenta o caso de uma compra e venda obrigatória, onde o comprador se encontra vinculado a uma obrigação diante da existência da compra e venda e, em decorrência disso, procede à entrega da coisa.

A natureza desse pagamento, i.e, a obrigação contraída por compra e venda é que faz com que se usucapa pro emptore e não pro soluto, logo, o usucapião somente será pro emptore quando existir efetivamente a compra e venda, pois, como o próprio Paulo afirma no final do fragmento, não se pode usucapir pro emptore aquele que não comprou.

Para P. BONFANTE ${ }^{327}$, as principais sutilezas a respeito desse usucapião decorrem da estrutura da emptio-venditio romana, haja vista que esse contrato consensual, não obstante tenha como resultado a transferência da posse e o gozo absoluto sobre a coisa, não caracteriza, necessariamente, a transferência da propriedade.

Ressalta o autor, que a emptio-venditio pode até ser, mas não é essencialmente direcionada à transmissão da propriedade.

Segundo o citado romanista, a principal singularidade sobre o usucapião pro emptore refere-se ao fato de que a validade do título deve se preocupar com o momento do contrato, a fim de verificar se este é ou não eficaz, pois a solutio de uma compra e venda não é idônea para constituir a causa próxima da relação.

Em relação à segunda singularidade, que embora tenha sido mais comentada pela doutrina, para o mencionado romanista é a menos importante, refere-se ao momento da boa-fé na compra e venda.

A boa-fé atinge a essência natural da relação, logo, emergiu perante a doutrina a preocupação se ela deveria ocorrer no momento do contrato ou no momento da tradição.

Grande parte desses estudos recaem sobre as divergências entre os Sabinianos e 
Proculeianos.

Em comum, as duas escolas concordam com a exigência da boa-fé no momento do contrato.

Contudo, os Sabinianos, aderindo à chamada "teoria dos dois tempos" - a qual foi acolhida pelo direito justinianeu -, entendem que essa boa-fé é exigida também no momento da tradição.

Exemplo da adoção da teoria dos dois tempos seria o texto de Paulo, D. 41, 4, 2 pr., onde se verifica que a boa-fé deve estar presente em ambos os momentos.

P. BONFANTE ${ }^{328}$ ressalta que esse texto é o único que trata, pura e simplesmente, da emptio em matéria de usucapião.

O autor acompanha a opinião de R. StintZing ${ }^{329}$, e de V. ScIALOJA ${ }^{330}$, de que a compra e venda no momento do contrato deve ocorrer como um complemento obrigatório do título, posto que ela não implica obrigatoriamente na transferência da propriedade.

Consequentemente, por considerar a ideia arbitrária e antiromana, P. BONFANTE teceu críticas ao entendimento de B. WINDSCHEID, o qual expôs e corrigiu o pensamento de E. HUSCHKE, no sentido de que a atenção deve se voltar ao momento do contrato, pois ali já se teria um "início de apropriação" ${ }^{331}$.

No mais, assim como o texto de Papiniano, D. 41, 8, 3, o fragmento D. 41, 4, 2 pr. é um caso de exigência do título verdadeiro.

O fragmento D. 41, 3, 10 pr., o qual é tido por P. BONFANTE ${ }^{332}$ como obscuro, pois nele Ulpiano, Sabino e Cássio teriam dito, em detrimento tanto à teoria dos dois tempos quanto àquela defendida pelos Proculeianos, que a boa-fé deve se dar no momento da tradição.

Todavia, adverte o autor que se o fragmento for entendido dessa forma, não se conciliará com o entendimento de Paulo, jurisconsulto que adota a teoria dos dois tempos.

A solução que chegou o escritor em comento, é que o texto de Ulpiano deve ser

\footnotetext{
${ }^{327}$ Le singole cit. (nota 10 supra), p. 579.

${ }^{328}$ Le singole cit. (nota 10 supra), p. 582.

${ }^{329}$ Bona fides, pp. 113-117, cit. por P. BONFANTE, Le singole cit. (nota 10 supra), p. 583.

${ }^{330}$ Lezioni, 1888-1889, p. 230, cit. por P. BONFANTE, Le singole cit. (nota 10 supra), p. 583

${ }^{331}$ E. HuschKe, Das R. publ. Klage, B. WindscheId, Pand., 1, § 177, p. 610, C. ApPleton, Publicienne, I, p. 179-1894, cit. por P. BONFANTE, Le singole cit. (nota 10 supra), p. 585.

${ }^{332}$ Le singole cit. (nota 10 supra), p. 589.
} 
contextualizado com os demais textos constantes no livro XVI dos Comentários ao Edito, o qual é integralmente dedicado à Publiciana.

Assim, sendo o texto direcionado ao objeto específico da Publiciana, o que se mostraria relevante não é o momento em que a boa-fé deveria estar presente, mas sim o fato de que ela seria efetivamente exigida na tradição para fim de actio Pubiciana.

Prevaleceu o entendimento da escola sabiniana, onde, mesmo na emptio-venditio bonae fidei, a boa-fé era também exigida no momento da tradição.

Em relação a esse entendimento $\mathrm{L}$. VACCA ${ }^{333}$ acompanha o pensamento de $\mathrm{P}$. BONFANTE $^{334}$.

Quanto ao pagamento do preço, entendem que ele é essencial para o usucapião A. VANGEROW $^{335}$, B. WindSCHEID ${ }^{336}$, além de P. BONFANTE ${ }^{337}$.

Fundamentando em Gaio, D. 6, 2, 8, compartilham do pensamento contrário, C.

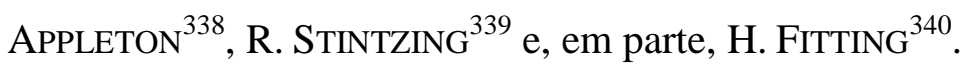

P. Bonfante cita dois casos relevantes à análise do título putativo, o primeiro, o fragmento D. 41, 4, 2, 8 de Paulo, o qual trata do caso de um tutor que adquire os bens dos quais acreditava pertencer ao pupilo.

O segundo, o fragmento subsequente, D. 41, 4, 2, 9, referente à aquisição feita pelo mandatário, onde, utilitatis causa, autorizava-se o usucapião pro emptore.

Tais casos no entendimento do citado romanista italiano, referem-se a hipóteses excepcionais, onde a presença da iusta causa é incerta, todavia, os textos são genuínos ${ }^{341}$.

Diante da ausência de lesão do tutor em relação o pupilo e do mandatário em relação ao mandante e, simultaneamente, uma vez verificada a boa-fé do tutor e do mandatário, autoriza-se o usucapião pro emptore.

Todavia, para o autor, este entendimento teria sido aplicado utilitatis causa. Paulo teria desenvolvido essa solução para essas únicas hipóteses, contudo, fundadas em uma iustae

\footnotetext{
333 “Iusta causa” e "bona fides" cit. (nt. 12 supra), p. 1.967-1968.

${ }^{334}$ Le singole cit. (nota 10 supra), p. 592.

335 Pand., I, § 320, nota 2, n. 1, in fine; cit. por P. BonfANTE, Le singole cit. (nota 10 supra), p. 593.

${ }^{336}$ Pand., I, § 179, n.1, cit. por P. BONFANTE, Le singole cit. (nota 10 supra), p. 593.

${ }^{337}$ Le singole cit. (nota 10 supra), p. 593.

${ }^{338}$ Publicienne, I, pp. 216 e ss.; cit. por P. BONFANTE, Le singole cit. (nota 10 supra), p. 593.

${ }^{339}$ Das Wesen der b. f. pp. 110-112, cit. por P. BONFANTE, Le singole cit. (nota 10 supra), p. 593.

${ }^{340}$ Arch. für civ. Praxis, vol. LI, pp. 18 e ss. cit. por P. BONFANTE, Le singole cit. (nota 10 supra), p. 593.

${ }^{341}$ P. BONFANTE, Le singole cit. (nota 10 supra), p. 669-670.
} 
causae aparentemente verdadeira.

Aduz o mencionado estudioso, que a autoridade invocada de jurisconsultos mais antigos, como Sérvio, Marcelo, e o modo de se expressar (decursum est; utilitatis causa potest dici ... propter eandem utilitatem; dicimus ... ut hic plus sit etc; post magnas varietates obtinuiti), torna explícito que esses textos referiam-se a meros dipositivos de direito singular.

O fragmento D. 41, 4, 2, 8 também teria sido um desses casos, pois teria sido objeto de discussões imperiais entre os jurisconsultos: "idque et a divo Traiano constitutum dicitur" 342 ,".

Em relação à compra e venda contratada com incapaz, a primeira consideração que se deve fazer é que o tratamento dado pelos romanos para as diferentes incapacidades, também faziam jus a soluções diferenciadas.

Em relação à compra e venda contratada com o louco, o jurisconsulto Gaio, em D. 44, $7,1,12$, afirma que elas são nulas por natureza.

Contrapõe o entendimento de Gaio, o texto de Paulo, D. 41, 4, 2, 16, onde se admite utilitatis causa a compra de algo pertencente a um louco, caso o comprador desconheça essa condição.

Já em relação aos menores de idade, o mesmo jurisconsulto, no texto seguinte, admite que ele possa estipular ou prometer (pois já sabe falar), dando o indício do reconhecimento de uma incapacidade relativa.

Em D. 6, 2, 13, 2, Gaio decide que aquele que comprou de um pupilo, deve provar que comprou com a autorização de um tutor e sem proibição legal.

Já Paulo, em D. 41, 4, 2, 15, determina que aquele que compra de um pupilo com a crença de que ele já era púbere, procederá o usucapião, no entanto, caso saiba que da verdadeira situação do pupilo, não poderá usucapir, pois o erro de direito não se aplica em favor de ninguém.

A primeira evidência que se extrai do texto de Paulo é a importância que ele atribui à boa-fé.

Também Ulpiano, em D. 6, 2, 7, 4, em relação à Publiciana, decide que é admissível como iusta causa, a compra de algo pertencente a um menor, quando o comprador ignora esse fato.

${ }^{342}$ P. BONFANTE, Le singole cit. (nota 10 supra), p. 670. 
P. BONFANTE ${ }^{343}$, no que diz respeito à compra de algo pertencente aos loucos, destaca que estas são hipóteses devem ser analisadas objetivamente, pois a loucura é algo concreto e identificável, não sendo possível analisá-la somente à luz da bona fides, portanto, não guarda qualquer relação com o título putativo.

No que tange ao título pro legato, interessa-nos o estudo do legado per vindicationem.

Os textos de Ulpiano (D. 41, 8, 1), Paulo (D. 41, 8, 2) e Papiniano (D. 41, 8, 3) exigem o título verdadeiro para o usucapião, não bastando a crença de que a coisa tenha sido legada.

Em outra linha Javoleno, em D. 41, 8, 5, admite o usucapião pro legato de bens pertencentes a um testador ainda vivo.

Pompônio, em D. 41, 8, 6, admite o usucapião quando o possuidor legatário crê que o testador já tenha morrido, embora este ainda esteja vivo.

Mas o texto que apresenta a maior singularidade é o fragmento D. 41, 10, 4, 2 de Pompônio.

A hipótese refere-se a um herdeiro que recebeu algo indevidamente, sem que lhe tenha sido legado, mas a usucapiu pro legato, pois possuía a coisa pro suo.

Em relação a essa lei de Pompônio, afirma P. BONFAnTE ${ }^{344}$ ela se refere a um título verdadeiramente putativo, pois baseia-se na crença da existência de um legado que, na verdade, não existe, mas é assegurado ao possuidor o usucapião, pois possuiu pro suo.

Naquilo que toca aos títulos inominados, o citado autor afirma que a sentença e o juramento sequer podem ser considerados títulos de usucapião.

A adiudicatio, citada por Ulpiano entre as iustae causae, assim como o legado, é modo de aquisição de domínio, como se vê do texto de Marcelo, D. 41, 3, 33, 3.

Diz o autor que, mesmo diante da dificuldade em denominar essa causa, não se pode negar a exigência de uma iusta causa adquirendi.

Finalmente, tem-se o título pro suo, modalidade onde certamente se concentra as principais peculiaridades sobre o título putativo.

Paulo define a posse pro suo, em D. 41, 10, 2, como tudo o que capturamos do mar, terra e ar, ou que se faz nosso pelo aluvião dos rios, assim também os produtos de coisas que possuímos por outra causa, como o filho de uma escrava hereditária ou comprada ou o fruto

${ }^{343}$ Le singole cit. (nota 10 supra), p. 608. 
de uma coisa doada ou que se encontrava entre as coisas que recebemos em herança.

Ulpiano, em D. 41, 10, 1 traz outra definição, considerada a mais adequada para P. BONFANTE $^{345}$, a qual limita-se à seguinte ideia: quando acreditamos que uma coisa é nossa e a possuímos por qualquer causa, logo, possuímos pro suo.

Essa definição pode ser confrontada com o texto de Paulo. 41, 2, 3, 4, onde afirma que podemos possuir uma mesma coisa por diversas causas ao mesmo tempo, também pro suo.

Há divergências na doutrina sobre a posse pro suo.

Para o autor, possuir pro suo significa que se possuiu com base em uma iusta causa e se pode, portanto, usucapir, se já não se é proprietário.

Por outro lado, L. VACCA ${ }^{346}$ não reconhece essa iusta causa na posse pro suo. Para esta autora, a posse pro suo é tão somente uma espécie de posse e não causa, logo, quando os jurisconsultos asseguravam o usucapião pro suo, o faziam dispensando o título.

A crítica que faz a autora, é que a doutrina, querendo demonstrar a essencialidade do requisito da iusta causa, tentou forçar através de interpretações equivocadas, a existência de um título, se não real, imaginário.

Outra finalidade do título pro suo, como observou P. BONFANTE ${ }^{347}$, é que a denominação pro suo é um excelente refúgio para ter significado de posse ad usucapionem, quando a existência de uma iusta causa usucapionis não é duvidosa, mas o caráter ambíguo dela a deixa incerta a modalidade.

Em relação ao fragmento D. 41, 10, 5 de Nerácio, hipótese em se admite o usucapião com base na falsa existimatio apoiada em probabilis error do possuidor, o autor conclui que se está diante de um caso de admissão do título putativo.

Em oposição, L. VACCA ${ }^{348}$ sustenta que o fragmento atém-se mais ao problema da boa-fé do que ao título.

A autora embasa seu entendimento em T. MAYER-MALY que teria interpretado o texto não como afirmação genérica do título putativo, mas sim de maneira mais restritiva em

\footnotetext{
${ }^{344}$ Le singole cit. (nota 10 supra), p. 617.

${ }^{345}$ Le singole cit. (nota 10 supra), p. 631.

346 “Iusta causa” e "bona fides" cit. (nt. 12 supra), p. 1.980-1981.

${ }^{347}$ Le singole cit. (nota 10 supra), p. 633-634.

348 "I usta causa" e "bona fides" cit. (nt. 12 supra), p. 1.960.
} 
relação à doutrina tradicional, pois examinou a questão de maneira vinculada à teoria do tolerabilis error com a finalidade da boa-fé $\mathrm{e}^{349}$.

Contudo, segundo P. BonfAnte ${ }^{350}$, ainda que o texto apresente uma evidência da admissão do título putativo, deve-se ressaltar que I. ALIBRANDI indica-o como objeto de interpolação.

Além desse fragmento, I. ALIBRANDI declara que são interpolados o fragmento D. 41, 4, 11 de Africano, que é outro texto ao qual a doutrina costuma indicar como um caso de admissão do título putativo, juntamente ao texto D. 41, 10, 4, 2 de Pompônio.

Já as leis D. 41, 10, 4, 2 de Pompônio, e D. 23, 3, 67 de Próculo, foram apontadas como objeto de interpolação por A. PERNICE ${ }^{351}$.

No que tange ao título pro herede, o fragmento de Pompônio D. 41, 5, 3, o qual trata da hipótese do herdeiro verdadeiro usucapir algo que ele acredita, equivocadamente, que faz parte da herança.

P. BONFANTE ${ }^{352}$ não nega que esse texto tenha influenciado doutrinadores a reconhecer nele um caso de admissão do título putativo.

No entanto, para o autor, Pompônio deveria admitir esse usucapião através de um título específico ou como fez Nerácio, por intermédio do título pro suo, mas os compiladores preferiram encaixá-lo no título pro herede.

O autor conclui que existência de contradição entre os fragmentos de Pompônio e os rescritos imperiais, especialmente em relação aos conceitos acerca da iusta causa usucapionis e a iusta causa erroris, exceto se essa contradição no Codex e no Digesto for atribuída à distração dos compiladores justinianeus.

Contudo, o fato é que, verdadeiro ou putativo, Pompônio admite o usucapião com base na crença do herdeiro.

Conclui P. BONFANTE ${ }^{353}$ que o mesmo rigor com que Justiniano codificou o título verdadeiro, ele também codificou o título putativo.

\footnotetext{
${ }^{349}$ Das Putativtitelproblem cit. (nota 13 supra), p. 55, cit. por L. VACCA, “Iusta causa” e "bona fides" cit. (nt. 12 supra), p. 1.961.

${ }^{350}$ Le singole cit. (nota 10 supra), p. 678.

${ }^{351}$ P. BONFANTE, Le singole cit. (nota 10 supra), p. 678.

${ }^{352}$ Le singole cit. (nota 10 supra), p. 645.

${ }^{353}$ Le singole cit. (nota 10 supra), p. 679.
} 
Por conta disso, a limitação da iusta causa erroris, do probabilis error, da non levis praesumptio, não podia ser estranha aos defensores clássicos do título putativo.

Assevera, outrossim, que a codificação do título putativo não representava uma reação à teoria do título verdadeiro, como se pretendesse alçar o título putativo a uma condição de equivalência ao a verdadeiro, estabelecendo assim a escusabilidade do erro.

O que pretendia essa codificação era atribuir uma solução a uma questão de fato, a existência ou não da boa-fé.

Segundo o autor, a prova definitiva do verdadeiro espírito da legislação justinianeia nos é dada pelos Bizantinos.

Para os Bizantinos, com a mesma versão dos textos clássicos, o requisito da iusta causa desaparece ou acaba se fundido à bona fides.

Ademais, quanto era identificada a ausência do título verdadeiro, as existem decisões não eram focadas na equiparação do título putativo com ele, mas sim sobre a admissibilidade excepcional do usucapião.

Ressalta-se P. BONFANTE ${ }^{354}$, todavia, que as decisões assim concebidas decorrem daqueles que defendem o título verdadeiro.

Em relação aos defensores do título putativo, é possível que eles excluíssem algumas causas.

Ademais, para o autor, também essa hipótese pode ser verdadeira, porém dificilmente será considerada para a configuração originária daquela que nós deveríamos chamar de teoria da boa-fé, mas chamamos de teoria do título putativo.

\footnotetext{
${ }^{354}$ Le singole cit. (nota 10 supra), p. 681.
} 


\section{RESUMO}

O presente trabalho refere-se ao estudo do título putativo no âmbito da usucapio romana.

A iusta causa é um dos requisitos fundamentais da usucapio, diante disso, a jurisprudência romana discutia se o usucapião deveria se proceder apenas diante a existência do título verdadeiro, ou se bastava a crença por parte do possuidor (título putativo) para que a usucapio acontecesse.

A doutrina romanística, ao analisar os textos romanos, sugere que alguns textos referem-se a fortes indícios da admissão desse título, a exemplo do fragmento $\mathrm{D}, 41,10,5$ de Nerácio, considerado, para muitos, o principal texto referente ao título putativo, e o fragmento D. 41, 10, 4, 2, de Pompônio.

Entretanto, esse entendimento não é pacífico, na medida em que há quem considere que, na verdade, os referidos fragmentos do Digesto não guardavam relação com a admissão do título putativo, mas sim, que os referidos casos tratavam da verdadeira dispensa da causa para a admissão de uma usucapio que se procederia exclusivamente com base na boa-fé.

O trabalho aborda a questão da causa na usucapio em suas diferentes modalidades: pro derelicto, pro emptore, pro legato, pro donato, pro dote, pro solutio, pro herede, também em relação aos chamados "títulos inominados" e na modalidade que, para muitos, é o principal ponto da controvérsia sobre o título putativo, usucapio pro suo.

O estudo das diferentes espécies da usucapio é acompanhado pelos respectivos textos romanos. 


\begin{abstract}
This paper refers to the study of the putative causa within the Roman usucapio.

The iusta causa is one of the fundamental requirements of usucapio, thereby, the Roman jurisprudence used to discuss whether the prescription should be undertaken only on the existence of the true causa, or if the belief of the holder was enough (putative causa) for the usucapio to happen .

The romanistics studies, analyzing the Roman texts, suggests that some texts refer to strong admission of the evidence of that causa, like Neratius fragment D, 41, 10, 5, considered by many, the main text of the putative causa, and Pomponius fragment D. 41, 10, 4,2 .

However, this is not a peaceful understanding, in the way that, there are some that consider that, in fact, those Digest fragments did not keep relation with the admission of the putative causa, but that those cases dealt with the real cause for the dismissal of acceptance of a usucapio that proceed exclusively based on good faith.

This paper addresses the question of the causa in usucapio in its different kinds: pro derelicto, pro emptore, pro legato, pro donato, pro dote, pro solutio, pro herede, also in relation to others causae, and in the form that, for many, is the main point of controversy over the putative causa, the usucapio pro suo.
\end{abstract}

The study of different kinds of usucapio is accompanied by their texts of Roman law. 


\section{BIBLIOGRAFIA}

Albertario, Emilio, Corso di Diritto Romano - possesso e quasi possesso, Milano, Giufrré, 1946.

Arangio-RuIZ, Vincenzo, Instituzioni di Diritto Romano, 14ª ed., Napoli, Jovene, 2006. , Storia del Diritto Romano, $7^{\mathrm{a}}$ ed., Napoli, Jovene, 1984.

BONFANTE, Pietro, Essenza della "bona fides" e suo rapporto colla teorica dell'errore in Scritti Giuridici Varii, II, Milano, UTET, 1918.

I limiti originari dell'usucapione in Scritti Giuridici Varii, II, Milano, UTET, 1918.

, Le singole "iustae causae usucapionis" e il titolo putativo in Scritti

Giuridici Varii, II, Proprietà e Servitù - Milano, UTET, 1918.

Correia, Alexandre e Sciascia, Gaetano, Manual de Direito Romano, Rio de Janeiro, SEDEGRA, 1968.

FABBRINI, Fabrizio, Usucapione, in Novissimo Digesto Italiano, XX, Torino, UTET.

FAURE, Jules, "Iusta causa” et "bonne foi, Lausane, Universitè Lausanne, 1936.

GuARINO, Antonio, Storia del Diritto Romano, 12ª ed., Napoli, Jovene, 1998.

KASER, Max, Römisches Privatrecht, Munique, Beck'sche, 1992, trad. port. RoDRIGUES, Samuel, Hämmerle, Ferdinand, Direito Privado Romano, Lisboa, Calouste Gulberkian, 1999.

MARKy, Thomas, Curso Elementar de Direito Romano, $8^{\mathrm{a}}$ ed., São Paulo, Saraiva, 1995.

Marrone, Matteo, Istituzioni di Diritto Romano, Palermo, Palumbo, 2006.

MAY, Gaston, Élément de Droit Romain, 18ª edição, Paris, Recuel Sirey, 1932.

MaynZ, Charles, Droit Romain, $5^{\text {a }}$ ed., Paris, Tome I, A. Durand \& Pedone-Lauriel, 1891.

MAYER-MALY, Theo, Das putativ Titelproblem bei der usucapio, Graz-Colônia, Hermann 
Böhlaus Nachf., 1962.

Mommsen, Theodor, Krueger, Paul, Digesta Iustiniani Augusti, II, Berolini, Weidmann, 1870.

Moreira Alves, José Carlos, Direito Romano, 15ª ed., Rio de Janeiro, Forense, 2012.

PEROzZI, Silvio, Istituzioni di diritto romano, I, Roma, Athenaeum, 1928

Pugliese, Giovanni, Istituzioni di Diritto Romano, 2a ed., Torino, G. Giapicheli, 1990.

Riccobono, Salvatore, Corso di Diritto Romano - Il Possesso - anno accademico 1933/1934, Roma, Giufrée, 1935.

Fontes iuris Romani antejustiniani, 1, Firenze, 1941.

Santos Justo, António, Direito Privado Romano III - Direitos Reais, in Boletim da Faculdade de Direito da Universidade de Coimbra, Coimbra, Coimbra Editora, 1997.

SCIAlOJA, Vittorio, Teoria della proprietà nel diritto romano, lezioni ordinate curate edite da Pietro Bonfante, vol. 2, Spoleto, Anonima Romana, 1933.

Talamanca, Mario, Istituzioni di Diritto Romano, Milano, Giuffrè, 1990.

VACCA, Letizia, "Iusta causa" e "bona fides" nell'"usucapio" romana - A proposito del titolo pro suo, in Sodalitas, Scritti in onore di A.Guarino, 4, Jovene, Napoli, 1984.

, La strutura originaria dell'usucapione, in Enciclopedia del diritto, vol. XLV, Milano, Giuffrè, 1992.

Vendrand-Voyer, Jacqueline, Possessio Pro Suo in Sodalitas - Scritti in onore di Antonio Guarino, 3, Jovene, Napoli, 1984.

VoCI, Pasquale, “Iusta causa traditionis” e “iusta causa usucapionis”, SDHI, 15, 1949.

WolODKIEWICZ, Wiltold, Alcune osservazioni sull'aplicazione del principio "iuris ignorantiam in usucapione negatur prodesse", in Studi in onore di Edoardo Volterra, vol. I, Giuffré, Milano, 1971. 


\section{INDICE DAS FONTES}

\section{A. Fontes Pré-justinianeias}

FRAGMENTA VATICANA

$\begin{array}{ll}\text { Frag. Vat. } 1 & \text { p. } 54\end{array}$

Frag. Vat. $111 \quad$ p. 32

Frag. Vat. $260 \quad$ p. 260

Frag. Vat. $261 \quad$ p. 261

\section{B. Fontes Justinianeias}

CORPUS IURIS CIVILIS

DIGESTA

D. $5,3,13,1 \quad$ p. 93

$\begin{array}{ll}\text { D. } 6,1,17,1 & \text { p. } 87\end{array}$

$\begin{array}{ll}\text { D. } 6,1,20 & \text { p. } 87\end{array}$

$\begin{array}{ll}\text { D. } 6,1,26 & \text { p. } 80\end{array}$

$\begin{array}{ll}\text { D. } 6,2,4 & \text { p. } 22\end{array}$

$\begin{array}{ll}\text { D. } 6,2,7,2 & \text { p. } 70\end{array}$

$\begin{array}{ll}\text { D. } 6,2,7,4 & \text { p. } 69,135\end{array}$

D. $6,2,7,5 \quad$ p. 80

$\begin{array}{ll}\text { D. } 6,2,7,11 & \text { p. } 43,60\end{array}$

$\begin{array}{ll}\text { D. } 6,2,7,17 & \text { p. } 41,48,52,59\end{array}$

$\begin{array}{ll}\text { D. } 6,2,8 & \text { p. } 54,134\end{array}$

D. $6,2,11,4 \quad$ p. 95

$\begin{array}{ll}\text { D. } 6,2,13,1 \quad \text { p. } 93 & 9\end{array}$

D. $6,2,13,2 \quad$ p. 67,135

$\begin{array}{ll}\text { D. } 6,3,2,1 & \text { p. } 88\end{array}$

D. $12,2,13,1 \quad$ p. 83,85 

D. $12,2,13,5 \quad$ p. 85
D. $19,1,3$ pr. p. 39
$\begin{array}{ll}\text { D. } 21,1,44 & \text { p. } 129\end{array}$
D. $21,3,1,5 \quad$ p. 74
$\begin{array}{ll}\text { D. } 23,3,67 & \text { p. } 33,96,138\end{array}$
$\begin{array}{ll}\text { D. } 24,1,25 & \text { p. } 27\end{array}$
$\begin{array}{ll}\text { D. } 24,1,44 & \text { p. } 28\end{array}$
D. $25,2,22$ pr. p. 80
$\begin{array}{ll}\text { D. } 26,8,5 \text { pr. } & \text { p. } 69\end{array}$
D. $29,2,20,1 \quad$ p. 93
$\begin{array}{ll}\text { D. } 41,1,9,3 & \text { p. } 60,61\end{array}$
D. $41,2,21,1 \quad$ p. 15
D. $41,2,22,2 \quad$ p. 15
D. $41,2,24$ p. 116
D. $41,2,3,4 \quad$ p. 91,138
D. $41,3,4,5 \quad$ p. 117
$\begin{array}{ll}\text { D. } 41,3,4,17 & \text { p. } 22\end{array}$
D. $41,4,4,23$ p. 117
D. $41,3,4,24 \quad$ p. 117,126
D. $41,3,5 \quad$ p. $93,122,126$
D. $41,3,10$ pr. p. 133
D. $41,3,13$ pr. p. 93
D. $41,3,13,1 \quad$ p. 71
D. $41,3,15,3 \quad$ p. 22
$\begin{array}{ll}\text { D. } 41,3,17 & \text { p. } 80\end{array}$
D. $41,3,21 \quad$ p. 121
D. $41,3,27$ p. 61,96
D. $41,3,29$ p. 108,126
D. $41,3,32$ pr. p. 92
D. $41,3,33,1 \quad$ p. 125
D. $41,3,33,3 \quad$ p. $18,43,81,95,128,136$
D. $41,3,4 \quad$ p. 116
$\begin{array}{ll}\text { D. } 41,3,4,5 & \text { p. } 22,91\end{array}$
D. $41,3,10$ pr. p. $41,48,58,60$ 

D. $41,3,27$
p. 61
D. $41,3,29$
p. 125
D. $41,3,44,4$
p. 41,116
D. $41,3,44,5$
p. 121
D. $41,3,46$
p. 23,129
D. $41,3,48$
p. $21,38,41,42,52,56,60,128,132$
D. $41,4,1$
p. 80
D. $41,4,2$
p. 41,61
D. $41,4,2$ pr.
p. $22,41,52,60,61,133$
D. $41,4,2,2$
p. 61
D. $41,4,2,6$
p. 62
D. $41,4,2,8$
p. $62,134,135$
D. $41,4,2,9$
p. 62,134
D. $41,4,2,15$
p. 68,135
D. $41,4,2,16$
p. 69,135
D. $41,4,2,21$
p. 87
D. $41,4,3$
p. 80
D. $41,4,6$ pr.
121
D. $41,4,7,4$
p. 41,58
D. $41,4,10$
p. 95
D. $41,4,11$
p. 61,138
D. $41,5,1$
p. 114,121
D. $41,5,2$
p. 121
D. $41,5,3$
p. $105,121,138$
D. $41,6,1$
p. 24,129
D. $41,6,1,2$
p. 26
D; 41, 6, 2
p. 87
D. $41,6,3$
p. 26
D. $41,7,4$
p. 14,128
D. $41,7,6$
p. 14,128
D. $41,7,7$
p. 15,128
D. $41,8,1$
p. 73,136
D. $41,8,2$
p. 74,136
D. $41,8,3$
p. $61,74,133,136$ 

D. $41,8,4$,
p. 75,78
D. $41,8,5$
p. $76,115,136$
D. $41,8,6$
p. $76,115,136$
D. $41,8,8$
p. 74
D. $41,8,9$
p. 78
D. $41,9,1,2$
p. 31,130
D. $41,9,1,3$
p. 30
D. $41,9,1,4$
p. 30
D. $41,9,2$
p. 32,131
D. $41,10,1$
p. $91,92,138$
D. $41,10,1 \mathrm{pr}$.
p. 92
D. $41,10,2$
p. 90,136
D. $41,10,3$
p. 18,96
D. $41,10,4$ pr.
p. 96
D. $41,104,1$
p. 94
D. $41,10,4,2$
p. $96,136,138,141$
D. $41,10,3$
p. 96,128
D. $41,10,5$
p. $92,96,99,138,141$
D. $41,10,4,2$ p. 78
D. $43,2,1$ pr.
p. 112
D. $43,2,1$
p. 125
D. $44,7,1,12$
p. 66,135
D. $44,7,1,13$
p. 66
D. $46,3,60$
p. 22
D. $47,2,72(71)$
p. 119,126

\section{CODEX}
C. $3,31,7$
p. 110
C. $7,29,1$
p. 112
C. $7,29,2$
p. 113
C. $7,29,4$
p. 103,126
C. $7,31,3$
p. 122
C. $7,33,4$
p. 103,126
C. $7,34,4$
p. 110 